SAND92 - 7302

Unlimited Release

UC -251

\title{
Supply of Geothermal Power from Hydrothermal Sources: A Study of the Cost of Power in 20 and 40 Years
}

Susan Petty

Susan Petty Consulting

654 Glenmont Avenue

Solano Beach, CA 92075

B. J. Livesay

Livesay Consultants, Inc.

126 Countrywood Lane

Encinitas, CA 92024

William P. Long

Carlin Gold Company, Inc.

1240 East Main Street, Suite 3

Grass Valley, CA 95945

John Geyer

John Geyer and Associates

11914 Northeast 18th Street

Vancouver, WA 98684

Prepared by Sandia National Laboratories Albuquerque, New Mexico 87185 and Livermore. California 94550 tor the United States Department of Energy under Confract DE-AC04-76DP00789

Printed November 1992 


\section{DISCLAIMER}

This report was prepared as an account of work sponsored by an agency of the United States Government. Neither the United States Government nor any agency Thereof, nor any of their employees, makes any warranty, express or implied, or assumes any legal liability or responsibility for the accuracy, completeness, or usefulness of any information, apparatus, product, or process disclosed, or represents that its use would not infringe privately owned rights. Reference herein to any specific commercial product, process, or service by trade name, trademark, manufacturer, or otherwise does not necessarily constitute or imply its endorsement, recommendation, or favoring by the United States Government or any agency thereof. The views and opinions of authors expressed herein do not necessarily state or reflect those of the United States Government or any agency thereof. 


\section{DISCLAIMER}

Portions of this document may be illegible in electronic image products. Images are produced from the best available original document. 


\title{
Supply of Geothermal Power from Hydrothermal Sources: A Study of the Cost of Power in 20 and 40 Years
}

\author{
Susan Petty \\ Susan Petty Consulting \\ 654 Glenmont Avenue \\ Solano Beach, CA 92075 \\ B. J. Livesay \\ Livesay Consultants, Inc. \\ 126 Countrywood Lane \\ Encinitas, CA 92024 \\ William P. Long \\ Carlin Goid Company, Inc. \\ 1240 East Main Street, Suite 3 \\ Crass Valley, CA 95945 \\ John Geyer \\ John Geyer and Associates \\ 11914 Northeast 18th Street \\ Vancouver, WA 98684
}

\begin{abstract}
This study develops estimates for the amount of hydrothermal geothermal power that could be on line in 20 and 40 years. This study was intended to represent a "snapshot" in 20 and 40 years of the hydrothermal energy available for electric power production should a market exist for this power. This does not represent the total or maximum amount of hydrothermal power, but is instead an attempt to estimate the rate at which power could be on Iine constrained by the exploration, development and support infrastructure available to the geothermal industry, but not constrained by the potential market for power.

*The work described in this report was performed for 4

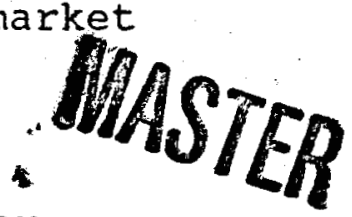
Sandia National Laboratories under Contract No. 66-8860.
\end{abstract}


SUPPLY OF GEOTHERMAL POWER FROM HYDROTHERMAL SOURCES:

A STUDY OF THE COST OF POWER IN 20 AND 40 YEARS

\subsection{Summary}

At the request of the DOE/Energy Information Agency and Geothermal Development Department a study was made to evaluate the amount of hydrothermal geothermal power that could be on 1 ine in 20 and 40 years. This study was intended to represent a "snapshot" in 20 and 40 years of the hydrothermal energy available for electric power production should a market exist for this power. This does not represent the total or maximum amount of hydrothermal power, but is instead an attempt to est imate the rate at which power could be on line constrained by the exploration, development and support infrastructure availabie to the geothermal industry, but not constrained by the potential market for power.

This study extended exfsting data bases prepared by the US Geological survey, the Bonnevilie Power Administration, the National Ocean and Atmosphere Administration and state energy offices and geological surveys with recentiy published exploration and development information and the input of geothermal developers, operators and exploration companies. The potential impact of evolutionary technology improvements on cost was calculated. Current DOE policy has concentrated research efforts on incremental technology changes, so revolutionary technology changes were not considered. However, revolutionary technology improvements may occur as a result of any research effort and would certainly have a larger impact on cost than the incremental improvements assumed for this study. Twenty-three individuals in the geothermal development industry, including reservoir engineers, geologists; production engineers, project managers, and management, were contacted in order to up date the published data bases. In addition state energy offices and utility contacts were asked to review resource estimates made by industry.

This study found that a minimum of 27,400 MWe of geothermal power from hydrothermal sources will be available for development in the next 40 years if only those resources now toentified are considered. The majority of this power, 22,000 MWe, should cost less than $120 \mathrm{mils} / \mathrm{kW}-\mathrm{hr}$ to produce. About $18,000 \mathrm{MWe}$ would be avaliable at less than $75 \mathrm{mlls} / \mathrm{kw}-\mathrm{hr}$. Incremental technology improvement could decrease the cost of developing the more expensive resources by as much as $53 \%$ 
since not all potential geothermal resources have been currently identified, an estimate of the unidentified resources which could become available over the next 40 years was made. When these resources are included the total available resource base in 40 years is estimated at 50,000 MWe. Even at current technology levels this could mean 30,000 MWe at less than $75 \mathrm{mils} / \mathrm{kw}-\mathrm{hr}$.

These estimates do not include the widespread non-electric use of geothermal power for space heating, industrial processes, agriculture and aquaculture. The energy displaced by the rapidiy growing use of geothermal or groundwater source heat pumps which result in significant reduction in use of other energy sources for space heating and cooling was also not estimated for this study. The potential for electric power production from advanced technologies for extracting geothermal energy from geopressured reservoirs, hot dry rock heat sources and magma bodies was not projected for this study of hydrothermal electric power production.

Political, environmental, regulatory, transmission access and market constraints will limit the marketability of geothermal power. This study attempts to eliminate these market driven constraints and estimate the potential for geothermal power production independent of demand factors. Transmission costs were not included since these costs can change dramatically over a 40 year time frame as utilities expand and upgrade power transmission networks. All of these constraints have been demonstrated to be amenable to mitigation by regulatory change and government incentives.

\subsection{Geothermal Power Study}

This study was undertaken at the request of the Energy Information Agency to determine the supply of geothermal power in the western U.S. At the request of the EIA, the core states of Washington, Oregon, California, Nevada, Idaho and Utah were examined first, with all the states in regions 6 and $8-10$ added to the original task. Alaska was not included in this study although Hawaii was. The problems of access to geothermal areas in Alaska, especially the Aleutian Islands present a set of special circumstances which it was felt required further work.

The primary goal of the effort was to determine the available supply of electric power from geothermal resources and the cost of producing that power at present, in 20 years and in 40 years. It was a lso desired to estimate the change in cost of this power and in the supply of power available due to technological improvement.

The information in this report is intended for use in geothermal market penetration studies planned by the EIA. 
The investigation team consisted of a specialist in each of four areas: Reservoir engineering, well drilling, leasing and economics and power marketing. The team members are 1 isted below with a summary of their area of expertise and experience:

1. Susan Petty - Reservoir engineer with 11 years experience in flow testing and evaluation of geothermal resources. Responsible for gathering resource data into a database for use in calculating the cost of geothermal power and in assessing the size of each resource. Calculated cost of power using IMGEO code developed as part of an earlier study of impact of research on cost of power. Tested and analyzed data from many geothermal resources in the western U.S. including coso Hot Springs, Long Valley Caldera, Valles Caldera, East Mesa, Brawley, Niland, Salton Sea, Raft River, Soda Lake, Fish Lake, Fallon, Fernly, Desert Peak, the Geysers, and Puna.

2. B. J. Livesay, Ph.D. - Geothermal driliing engineer with over 25 years experience in drlliing technology. Responsible for well cost calculation. Involved with development of high temperature downhole instrumentation. Also provided resource input. Has drilling experience and knowledge of Coso Hot Springs, Salton Sea, Heber, East Mesa, the Geysers and Long Valley Caldera.

3. William P. Long, Ph.D. - Mineral economist with experience in the leasing and marketing of geothermal properties. Responsible for assessing resource economics and cross checking of calculated costs to produce power output from IMGEO code. Experienced with Rooseve1t Hot Springs, Fish Lake, Soda Lake, Medicine Lake, Desert Peak, Humbolt House and the Geysers.

4. John Geyer - Consultant in marketing of geothermal power. Responsible for assessing market penetration and checking power cost calculations. Currently working with citizen's Power to negotiate power sales agreements for geothermal developers. Knowledgeable about resources and power prices all over the western U.S., but in particular the Pacific Northwest.

A.

Resumes of the project team members are provided as Appendix

\subsection{Scope of the study}

Geothermal power is produced from the heat of the earth. The earth's heat can be used directly or converted to electrical power. some transport medium is needed to extract the heat from the earth. Hydrothermal resources rely on naturally occurring water or steam to sweep heat from reservoir rocks. Hot dry rock and magma energy require water from the surface to be added to artificialiy created cracks in the hot rocks to extract heat from the reservoir. Geopressured geothermal resources are a special case of hydrothermal resources in areas where deeply buried sediments 
contain hot fluids with dissolved methane under high pressure.

The energy carried to the surface through a geothermal well can be used directiy as heat through heat exchangers or heat pumps or can be converted to electric power. There are three primary electric power conversion processes. Dry steam plants use naturally occurring steam in conventional turbines to turn a generator. The earth acts as the boiler would in a conventional power plant. In hot water resources, the water boils at the surface or in the wellbore, the steam is separated from the water and used to turn a turbine in a single or dual flash process. Geothermal hot water can also be used to heat a working fluid which boi $7 s$ and turns a turbine in a binary power plant.

Hydrothermal resources were given primary consideration for this study, but advanced technologies such as hot dry rock or magma energy may be available and economic over the next forty years. The amount of energy in hot dry rock resources alone could be extremely large and may have a considerable impact on the future of energy development in the United States. The size of the task of evaluation of hot dry rock and magma energy was such that it was decided to leave this for a separate study.

Although past studies have considered only resources above $150^{\circ} \mathrm{C}$ to be suitable for electrical generation, this is not a technology limitation. Current binary technology could make power from resources with temperatures as $10 \mathrm{w}$ as $90^{\circ} \mathrm{C}$, although this would be very inefficient and costly. However, the recent construction and operation of a power plant using fluid with a temperature close to $110^{\circ} \mathrm{C}$ in the Wendel1-Amedee Known Geothermal Area suggested a drop in the lower limit for electric power generation would be appropriate for this study. Since existing technology and economics make this project economic, a temperature cut off of $1100 \mathrm{C}$ was used for the lower 1 imit in this study:

\section{Resource assessment}

The supply of geothermal power assessment was based on three sources: 1) USGS Circular 790 estimates of hydrothermal electric power, 2) Other published reports including the NOAA maps of geothermal resources for the states of California, Nevada, New Mexico, Washington, Oregon, Colorado, Montana, Idaho and Utah, the Bonneville Power Resource Assessment of geothermal electric power in the Pacific Northwest and other published reports and scientific papers, 3) Personal knowledge on the part of the investigative team and their contacts in the geothermal business.

Using circular 790 as a starting point, 1 ists were made of all the resources in the states of California, Nevada, Oregon, Washington, Idaho and Utah which the USGS felt had any potential for generating power. The original intention was to use the USGS 
temperature 1 imit of $150^{\circ} \mathrm{C}$ as the cut off for power generation. However, we also wanted to assess the cost of producing power from any resource for which it is technically feasible regardless of current power production economics. Resources which are currently not economic may become economic in the future through technologic advances or through changes in the economy. Also, a power plant at Amedee in northern California from a $108^{\circ} \mathrm{C}$ resource. It may be expensive to produce power from such low temperature resources, but it is certainly technically feasible. Since the study was also aimed at determining the impact of research on the cost of power in the future we lowered the temperature cut off for electric grade resources to $110 \mathrm{C}$.

Since the USGS 1 imited electric grade resources to those above $150^{\circ} \mathrm{C}$ it was necessary to use their data on low to moderate temperature resources to estimate the potential for lower temperature power production. The USGS and many other studies give their low temperature data in terms of recoverable heat. We used a conversion efficiency of $25 \%$ and an availability of $90 \%$ for 30 years to calculate the amount of potential electric power production from these low temperature resources. A conversion efficiency of $25 \%$ is lower than the $33 \%$ conversion efficiency used by the USGS in their estimates of recoverable power from higher temperature resources, but for low temperature resources it was felt that this was more reasonable. Geothermal power plants usually have a very high avallability factor, often exceeding $95 \%$. An availability of $90 \%$ was considered conservative for geothermal power generation even though utilities normally use $80-85 \%$.

Once the lists of resources from USGS Circular 790 had been generated we checked the Bonnevilie Power study of the Pacific Northwest to augment the resources in the Cascades. The UsGS considered a resource identified oniy if it had some surface manifestation such as hot springs, fumaroles or geysers or if a well had been drilled into the resource. The presence of very high heat flow, active volcanism or hydrothermal alteration was not consfdered indicative of a hydrothermal resource. However, in the Cascades very high rainfall tends to sweep heat away from the surface so that hot springs and other surface thermal features don't often occur. The Bonnevilie Power study used recent drilling activity, active volcanism and the existence of high heat flow anomalies to identify many more resources than the USGS sited.

The identified resources were then checked against state geothermal maps prepared under the auspices of National Ocean and Atmosphere Administration (NOAA). Several further resources were added to the 1 ists from these maps.

We then gathered information on temperature, depth, well flow, geology and fluid chemistry for each resource. We used published reports, the state geothermal maps, USGS publications, personal knowledge and contacts with resource developers to obtain this 
information. We also checked our estimates of the recoverable power against these sources.

For some resources little information was available. For these resources we found a resource with available data with similar geology and reservoir conditions in the same physiographic province and state. The recoverable power from the low data resource was then added to power producible from the high data resource. The combined resource kept the name of the high data resource. The 1ist was thus shortened to a total of 54 resources.

\subsection{Geothermal electric power resource base}

The resource data base consisted of the resource temperature, depth to the resource, estimated average well flow rate and the total power producible from the resource. We looked at two scenarios for estimating the size of the total hydrothermal resource base: 1) The identified resource base with current exploration technology, and 2) The unidentified resource base with accelerated exploration scenario. The current exploration scenario includes only the identified resource base and makes some judgements about what can reasonably be brought on 1 ine over the next 40 years. The accelerated exploration scenario was intended to provide an estimate of the unidentified resource base and assumes an increased pace for exploration than that currentiy underway.

We first estimated the identified resource base available over time. Identified resources are defined as those with some surface manifestation such as hot springs, fumaroles, active volcanos or other thermal features or those with high heat flow or a well with anomolously high temperatures. A resource would be available for development if land were leased and an active program of exploration were under way. We tried to base these estimates on how much hydrothermal energy would be available for sale not on how much could be sold. In other words we attempted to eliminate considerations such as project economics, environmental constraints, proximity to power transmission ines, the local market for power, social and political considerations. These estimates are limited by exploration technology, the availability of exploration equipment and infrastructure and the rate at which this type of exploration can proceed.

We started by determining the amount of power currently on line at each resource or the amount of power which would be on 1 ine within the next five years. For power to be on 1 ine in five years we required that a power plant be under construction or a firm power sales agreement with permits for plant construction to be in effect. We then looked at the status of exploration at the resource. If active exploration was under way we contacted the developer to ask how much power they felt could be on 1 ine in 20 and 40 years if power sales agreements were possible. We felt it 
was important to eliminate institutional considerations from these estimates since sale of power, access to transmission lines, division of the resource into lease blocks and social and political factors are related to marketability not to the size of the available resource. If environmental factors limited the production of power we asked the developer to give us an estimate with and without environmental constraints. We used the estimates of power which neglect environmental considerations, but these factors should be considered separately in any marketability assessment.

For resources where active exploration is not ongoing, we estimated the possible resource available in 20 and 40 years using first the USGS estimate, then published data, our own judgement and industry contacts. In cases where no USGS estimate has been made and little is known about the resource and no current interest has been shown in exploring it, we estimated that 25\% of the total potential resource could be available in 20 years and $50 \%$ in 40 years. The Bonneville Power estimates of the size of the Cascades resources presented a special problem. Their estimates of recoverable power are based on estimates of the rock volume and heat content of rocks under cascades volcanos. The estimates in some cases are extremely large, much larger than any other existing hydrothermal resource. This heat may be recoverable, but possibly not as hydrothermal power. Since no existing hydrothermal resource in the US has proved larger than about 2000 . MWe, we felt that estimates of single resources larger than this size were unrealistic at the present time. Where exploration is ongoing we used estimates made by the developer, published reports and our own judgement. Where no exploration data is available we set a ceiling of 1000 MWe in 40 years, or half of the maximum of 2000 MWe, from an individual resource, with $25 x$ of that available in 20 years.

Another difficulty arose with the potential power from resources with temperatures between $110^{\circ} \mathrm{C}$ and $150^{\circ} \mathrm{C}$. Exploration of these resources is at a standstill at present. There is 1 ittle data available on most of them and the estimates of recoverable power made of USGS estimates of benefictal heat were extremely 1arge. For estimates of the current exploration scenario we assumed that $25 \%$ of this very large resource base could be avaliable in 40 years. The size of the resource base with power on line now or in 5 years, 20 years and 40 years is shown in Table 1.

Geothermal exploration has to date concentrated on the easy to find resources tied to some sort of surface manifestation such as a hot spring or recent volcanism. However, there should be many more resources as yet unidentified by either surface expression or current exploration efforts. It is important to make an attempt to quantify such resources since they may provide a long term, large electric power base. However, increased exploration would be needed to identify these resources. 
In order to examine the unidentified resource base and estimate the cost to develop, we needed to tie the costs found for the identified resources to the unidentified resources. Past estimates of the unidentified resource base, such as that made by the USGS in Circular 790, have just multiplied the total resource by some factor, in the case of the USGS, by five. since we wanted to estimate the supply at a cost to produce the power, this would not work for our study. Resources which are currently economic or relatively inexpensive to produce are more likely to have good data on their size. It is the marginal resources with high costs to produce that aren't being explored. These resources have not been explored because they are deep, moderate temperature, have no surface expression and thus require more expensive and less reliable exploration methods.

Therefore, in order to make a realistic estimate of the unidentified resource base, we expanded the size of the potential power production for the low temperature resources to the USGS Circular 790 estimate modified by our conversion to electric power. For the Cascades we either used the Bonneville Power estimates or doubled the current exploration estimate, whichever was smaller. For resources with ample data which were already under development, we used the USGS estimate, the estimate of the developer or our own judgement whichever was largest. For other resources we used the USGS estimate or 50x more than our current exploration estimate if the USGS estimate was smaller than our estimate for the identified resource base. Table 2 presents the data on the size of the identified and unidentified resource base under the accelerated exploration scenario. This is not to suggest that these unidentified resources would be found around the fringes of our identified resources, only that the cost to produce them, whatever their location, would be similar to extsting resources.

The USGS in circular 790 estimates the total identified hydrothermal resource base at $23,000 \pm 3400 \mathrm{MWe}$. They estimate the total unidentified hydrothermal resource base at between 72,000 and 127,000 MWe. This study estimates the identified hydrothermal resource base available in 20 years at 11,600 MWe and in 40 years at 27,400 MWe for 30 years. Including the unidentified resources, this study estimates that 18,000 MWe could be available in 20 years and 50,000 MWe could be avaliable in 40 years. It should be remembered that although these numbers are smaller than the USGS estimates of the total hydrothermal unidentified and identified resources, the estimates made for this study include consideration of the time needed for exploration. In other words the estimates made for this study include a time component and do not represent the total hydrothermal resource base.

\subsection{Cost of electric power}

The cost of producing electric power from each resource was 
calculated using IMGEO vers. 3.05. This model was developed as part of a DOE study of the impact of research on the cost of geothermal power. Since this study was concerned with calculating the change in cost of power over time, the IMGEO model was extremely useful for estimating the changes in cost of power due to improvements in technology with time. The model estimates the cost of the risk associated with development of geothermal resources by using a "best guess" value for critical reservoir parameters such as depth, temperature, well flow rate, etc., and a worst case estimate for each of these parameters. The model calculates the cost of power production using the best and worst case values. The difference in cost is the cost of the risk associated with lack of knowledge of the resource.

The model calculates levelized busbar costs on a revenue requirements basis following the recommendations of the EPRI Technical Assessment Guides of 1978. Costs are based on 1986 dollars. However, since well costs for IMGEO are calculated outside the model and entered as input values with risk, new well costs for each resource were calculated using the newly developed DRILCOS code. This code was developed as part of the ongoing study conducted by DOE of which IMGEO was the first phase. The well costs are therefore consistent with 1990 costs for actual geothermal wel1s. Because construction costs have not escalated rapidly in the past four years, the costs calculated by IMGEO should still be accurate within an error of $\pm 10 \%$. Some of the important financial assumptions made for IMGEO are included in Table 3. (See Traeger, Petty, Entingh and Livesay, 1988, for more detail about the IMGEO model.)

The cost of developing a geothermal resource is related to the geology of the resource as well as physical factors such as temperature, flowrate and depth. For IMGEO, geothermal resources were divided into four physiographic regions roughly equivalent to USGS physiographic provinces. The four regions are: 1) Imperial Valley, 2) Basin and Range, 3) Cascades and 4) Young Volcanics. Moderate and high temperature cases for each province were included. The young volcanics regions is a catch-all for hydrothermal resources associated with recent volcanism other than the Cascades. Cost factors such as fluid chemistry, number of dry holes per producer, number of injectors per producer, rate of well workover, cost of well workover, etc. are tied to these regional designations.

For this study the resources in the data base were assigned to a physiographic province. For each resource, individual temperatures, well flowrates and well depths were used as input for the IMGEO code. Some of the resources, particularly those in Colorado, Montana, and Idaho did not fit into the physiographic regions used for IMGEO. These resources were categorized as part of the region with closest geology and the input data was modified for IMGEO where necessary. 
For each physiographic region, a high temperature $\left(>200^{\circ} \mathrm{C}\right)$ flash steam case and a low temperature $\left(\angle 200^{\circ} \mathrm{C}\right.$ ) binary case was defined. Each resource was then assigned to either the flash steam or binary development default input for the appropriate physiographic region.

Three factors, temperature, depth and flowrate per we 11, were estimated for each resource as input to IMGEO. Risk values for these factors were also estimated. Large risk factors were imposed on the hypothetical cases used in the studies of the impact of research on cost of power done using the IMGEO code. The composite resources were meant to represent generic new developments prior to the start of exploration. For this study, specific data about each resource was known and the variation in the critical factors could be estimated. The difference between best and worst case values was therefore smaller than for previous published studies using IMGEO. Data on temperature was the easiest to obtain, so the difference between high and low temperatures was in general no more than $10 \%$ and on average was closer to 5\%. Flowrate is the hardest parameter to estimate for a resource. If actual flowrate data was not available, a risk of 15\% less flow was used for the IMGEO calculations. Values of reservoir parameters used for each of the resources are contained in the database accompanying this report as Appendix D. For all other factors used as input in the IMGEO calculations, the default values shown in Table 4 for the appropriate physiographic province were used as input. Table 5 shows the geothermal sites used ranked by cost with the state in which the site is located and the estimated resource size under the accelerated exploration scenario.

The cost of tying a geothermal power plant into the electric grid was included in plant cost estimates by IMGEO. However, the cost of transmitting geothermal electric power long distances to the electric power grid was not included in the calculations of power cost for this study. Geothermal power can not be transported except as electric power. Power has to be generated at the $s i t e$ of the resource. The cost of transmitting geothermal power from a remote location can be very high. Although transmission costs are an important part of the cost of producting geothermal power they are also directly impacted by utility decisions which are unrelated to the economics of geothermal resource development. For instance, the construction of north-south high capacity power lines between northern California and Oregon would be an important stimulant to geothermal development. The decision to build such $a$ ine is largely political and although geothermal power may be considered in this decision, it is not likely to be a primary factor. The changes in the utility transmission grid in the future are difficult to project. The cost of transmission lines to tie individual resources into the electric power grid needs to be estimated and included in calculating the cost of power production. However, this task was more time consuming than was possible for this study and so was left for future efforts. 
Figure 1 shows a plot of the supply of geothermal power from presently identified resources at costs ranging from about 20 $\mathrm{mills} / \mathrm{kw}-\mathrm{hr}$. up to $250 \mathrm{mills} / \mathrm{kw}-\mathrm{hr}$ assuming the current rate of technology improvement continues. This is the business as usual scenario, with few developers taking the risk of trying new technologies and a limited budget for government sponsored research. Figure 2 shows a similar plot with unidentified resources included in the total. Appendix $B$ contains the output from IMGEO used to produce, these cost/supply plots.

$250 \mathrm{mills} / \mathrm{kw}-\mathrm{hr}$ was used as an upper cost limit. Some upper limit had to be chosen to reduce the number of potential resources for consideration due to the lack of data on these less economic resources and the amount of time necessary to process this scarce data. However, it should be understood that this is an artificial cut off. Resources which are currently costly to produce are in general much more amenable to improvement in cost through research efforts. Future studies should include more of these low temperature, low productivity, deep, or high salinity resources.

For those familiar with traditional cost/supply curves, the curves calculated or this study may appear unfamiliar in shape. The cost/supply curve flattens with increasing cost of power. One would expect to find an ever increasing supply of power available with increasing cost to produce that power. The shape of these curves is caused by several factors all related to the fact that hydrothermal power is a natural resource. The scarcity of data on less explored resources 1 imits our knowledge of the amount of the more expensive to produce resources. The USGS and other published reports concentrate by necessity on identified resources. Data is most likely to be available on resources which are more economic to produce. Deep resources, resources with low temperatures or low potential productivity are not explored by either researchers or developers until more likely prospects are studied. Besides the lack of knowledge of deeper, lower temperature resources, the amount of expensive hydrothermal power is 1 imited by the nature of the resources. Geologic formations tend to decrease in permeability and porosity with depth as pressure closes fractures and compresses pore spaces. There is also a limit to the depth that conventional drilling technology can reach. Thus at some point hydrothermal resources become so low permeabllity that some artificial reservoir creation is needed to produce them. These resources then require hot dry rock technology to be productive. If the hot dry rock cost supply curve were superimposed on the hydrothermal curve, the total geothermal curve might look more like a cost supply curve for nuclear power.

When the unidentified resources were included in the cost/supply curves this flattening was reduced. Further study of unidentified resources could reveal the actual shape of the cost/supply curve. 
3.3 Comparison of calculated costs with actual and planned project costs

Once the cost to produce power for each resource had been calculated using IMGEO, developers and other experts in the geothermal field were contacted to check the validity of the calculated costs. In most cases it was not possible to obtain direct information on the cost to produce power at a particular. resource. Instead, contacts were asked to comment on the calculated cost to produce. In all cases of developed resources the calculated costs were within 2-5 mills/kw-hr of the actual cost to produce the power according to our sources. This gave us increased confidence in the validity of both the calculated costs and the data used as input.

The information about which developers were contacted and who provided comment on our cost calculations is highly confidential since at least two competitive bids for power contracts with utilities are currently in progress. Other fields are involved in law suits and release of any information related to cost to produce may jeopardize the outcome of these suits.

\subsection{Cost of power with new technology in $20 \& 40$ years}

The next step in the study was recalculating the cost to produce power given some reasonable assumptions about technology improvements over the next 40 years. IMGEO was used for these calculation with the following research and development achievements:

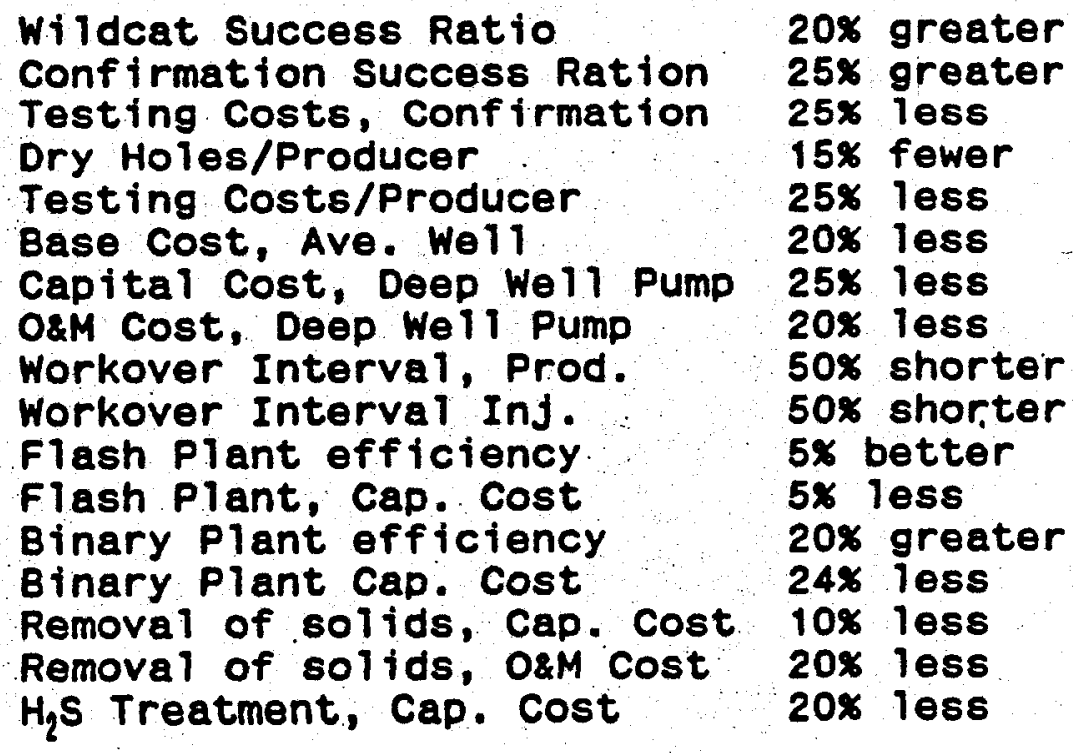

These research goals are a result of discussion with DOE researchers, developers and the project team of the maximum improvement possible using existing methods for each of the chosen R\&D impacts. No major breakthroughs in drilling, testing or 
exploration are considered. The improvements are through evolutionary change in currently available technology. The assumption was made by the project team that the maximum improvement could be reached by 2030 if this was the goal of the geothermal industry and government. Straight line interpolation was used between present cost of power and the R\&D impacted cost. Risk on these resources was not included as an R\&D impact for this phase of the study effort. Risk had been reduced for resources with good data available to levels currently accepted by developers when reservoir insurance is included in the cost of power as it is in the IMGEO model. For less well understood resources, risk costs are still fairly high. The impact of risk reduction research should be included in future phases, but time constraints prevented its inclusion at this stage.

DOE Geothermal research goals and objectives were examined for use in this modelling effort. Our team then examined the real istic evolutionary technology change possible for a range of technology improvements. Our results show that DOE goals for reducing total cost of power by 30 - 35\% are definitely achievable for high cost resources. For resources which are now economic, research would probably have less impact on cost, in the range of a $10-15 \%$ cost reduction. This is to be expected, since new technology would of necessity impact resources where larger number of wells, more expensive we17s, more difficult to handle fluids or deeper, harder to find resources are involved. In other words, if a resource can support a 50 MWe power plant with only 2 wel1s, reducing the cost of each wel1 by 10\% will have much less impact than a similar cost. reduction for a plant requiring 16 equally expensive wells to produce 50 MWe.

It is also important to consider the impact on cost of major breakthroughs which radically change technology. Driling technology makes a good example. Improvements in rate of penetration, cost of materials, bit life, etc. can potentially reduce the cost of drilling with conventional rotary technology. However, major costs such as cementing difficulties, lost circulation and casing cost are realiy not amenable to dramatic improvements. It is possible to imagine revolutionary technology changes which could circumvent the high cost of these areas which can not be greatiy improved using current methods. The development of casing which could be applied to borehole walls as drilling proceeds would radicaliy change the cost of geothermal wells. Lost circulation cost, casing cost, time to place casing and cement it all would be very much reduced. Future studies could look at the impact on cost of some of these revolutionary changes. Uniess a national energy emergency arises, research will continue to be directed toward improvement of existing technologies.

Figure 3 shows the supply of power at cost with technology improvement for the identified resources in Federal Regions 6 , and 8-10. Figure 4 shows a similar plot with unidentified resources 
included. The output from IMGEO showing the percentage cost reduction for each resource due to technology improvement is provided in Appendix B. The largest percentage impact in cost improvement was found for the resources with the highest cost to produce. This is as expected and suggests that further study of these high cost resources could increase the resource base.

Figure 5 shows the lowest estimates for amount of power with the highest cost, the identified resources using current technology bracketed by the highest estimates for power available at the lowest cost, the improved technology with unidentified and identified resources. This envelope shows the range of realistic values for power avallable in 20 years. Figure 6 shows the same scenarios at 40 years. Figure 7 shows a map of the composite sites used for the study.

Appendix C is a compilation of plots for separate regions with and without the inclusion of the unidentified resources.

\section{Current Power on Line}

Development of geothermal electric power began in 1958 at the Geysers. During the late 1970's and early 1980's power production at the Geysers progressed very rapidly with a maximum power production of 1948 MWe reached in 1986. Declines in wellhead pressure in the field due to overproduction of steam have reduced the total electric output at the Geysers to $1354 \mathrm{MWe}$ in 1990 (CA Energy Commission, 1990 Electricity Report). Along with reduced well head pressures, plants located on the edge of the field have experienced problems with plant operations caused by increasing non-condensible gases and corrosion. The CCPA Coldwater creek plant is currently operating only one unit due to corrosion problems. The other unit is being modified, however, and may be back on line in early 1991.

The pressure decline problems at the Geysers point out the risks associated with geothermal power production. However, long term management strategies involving injection of field condensate and imported water may mean a better outlook for this field, since the heat content of the rock in the field remains very high. It is important to understand that most estimates of resource size in this report are based on the size of the temperature anomaly observed for a particular area. The recoverable fluid is generally much smaller than the recoverable heat associated with a temperature anomaly. Injection of produced fluids increases the amount of heat which can be recovered and improves the potential for long project life. In hydrothermal systems, most developers plan an injection strategy which will maintain field pressures and increase heat recovery. Dry steam resources such as the Geysers must seek outside sources of water to augment steam reserves in place. Table 6 shows current generating capacity and actua 1 power production for the Geysers. The current geothermal installed 
capacity is 2810 MWe with 2163 on line. The shortfall is the result of production decline in the Geysers and operating and legal problems at Heber.

Table 7 shows non-Geysers power on line in California by geothermal area with power purchaser, steam or heat supplier, gross and net power production and capacity factor where known. For some fields power production has been consistently greater than the rated capacity for the plant and/or the amount of power contracted for by the purchasing utility. For these fields use of the rated capacity or the contract power sales to calculate the capacity factor results in a capacity factor greater than 100\%. Therefore, capacity factors greater than $100 \%$ are shown with the contract capacity in parentheses. Table 8 shows the same information for non-California power on line by state and geothermal area.

\section{Constraints on Marketability of Geothermal Power}

Utilities in the areas with geothermal power potential have different demands for power and varying acceptance of geothermal power as a potential power supply. The study team can work with the EIA to determine how the demand for power meshes with the supply of geothermal power. However, there are some constraints on the availability of geothermal power which are not directly related to the cost to produce power or the demand for that power, but which can affect both the marketability and the time frame for bringing power on 1 ine. These include: environmental constraints, political and social constraints, access to transmission 1 ines, and the utility and regulatory environment.

\subsection{Environmental Constraints on Geothermal Development}

This study considered several resources which have serious environmental restrictions on their development. These include:

Is land Park, Idaho - Adjoins Yellowstone National Park Crater Lake, 3 Creeks Butte, Oregon - Crater Lake National Park. Three Sisters Wilderness Area

Newberry Caldera, China Hat, Oregon - Deschutes National Forest

Long Valley Caldera, California - Mammoth Lakes Ski Area, near Yosemite National Park

Puna, Hawaij - Adjoins Volcanoes National Park

Kilauea, Hawail - In Volcanoes National Park

Mt. Lassen (inciudes Mt. Shasta), California - Lassen Volcanic National Park

Mt. Baker (includes Rainier, Adams and St. Helens), Washington - Northern Cascades National Park, Mt. Rainier National Park, Mt. St. Helens National Monument

Sespe Hot Springs, California - California Condor nesting 
area

These resources are al1 in or adjoining major national parks, wilderness areas or recreation areas. If it is impossible to develop these resources the total resource base would be reduced by as much as 9410 MWe. However, it is unlikely that restrictions on development would stop development entirely. Development would be more likely to be limited to the margins of these areas with severe restrictions on the appearance of any construction, noise, emissions, water quality and water sources. All of these restrictions could increase the cost of developing these resources and slow development while permits are obtained. However, it may be possible over a longer time period than the 40 years looked at for this study to extract all of the power possible from these resources using directional drilling and exercising extreme care in development.

Although the resources listed above which are in or adjoin National Parks, Recreation Areas or Monuments were included in the study, the hot, shallow resource at Yellowstone National Park was not included. All previous studies by the USGS have excluded Yellowstone. No developers have done any exploration in the Park. The USGS has drilled some scientific holes and there is some available data, but it is so unlikely that the Yellowstone resource would ever be made available for development or that development would even be allowed around the Park boundaries, that this resource was not evaluated for the study.

\subsection{Institutional Constraints on Geothermal Development}

Other factors may influence the rate at which power can be brought on line from geothermal resources. Issues which directly impact the rate of development include the number of geothermal development companies actively involved in exploration, the availability of federal land for leasing of geothermal rights and the social climate and politics of an area with geothermal resources. Access to transmission lines can severely limit the development of geothermal resources and if transmission costs are born by the developer, they can seriously impact the cost to produce power. The attitude of utilities and of utility regulators toward alternative energy sources and geothermal energy in particular can either facilitate rapid development or slow development to a snails pace. 5.2.1 Development fssues-based on current activity
level, land, political/social

Interest in and acceptance of geothermal power grew during the $1970^{\prime} \mathrm{s}$ and early $1980^{\prime} \mathrm{s}$ as oil prices climbed and the federal government enacted the Public Utility Regulatory Policy Act (PURPA) of 1978. In the early 80 's interest in renewable energy sources waned as oil prices stabilized and then declined. In 1983 large 
energy deficits predicted in the Pacific Northwest were replaced by predictions of surpluses.

The result of these changes is that only a very few developers remain actively involved in geothermal exploration and development. One major oil company, UNOCAL, and a few geothermal companies such as Magma, California Energy Company, Geysers Geothermal, Pacific Energy, Oxbow Geothermal and Ormat are still active. Other companies have declared bankruptcy or sold out their geothermal lease holdings. Because of this shortage of companies actively developing geothermal power, increases in demand for power may not be met with increases in supply. There is bound to be a lag in the ability of those holding geothermal leases who have cut back on exploration and development staff to move toward active development. Leases may also be caught in the limbo of court controlled bankruptcy proceedings. Other companies have defaulted on federal lease payments and allowed leases to return to the control of the Bureau of Land Management.

Leasing of geothermal rights by the Bureau of Land Management has slowed to a standstill. Recent queries concerning the time table for preparation of bid packages for leases allowed to revert to the BLM in southern California were answered with probable time lapse of two years prior to releasing of these lands. New leases in competitive bid areas are not proceeding at all.

The political climate in some areas has also stymied geothermal development. While interest in alternative energy sources has declined, public distress over environmental degradation has increased. Even though geothermal energy presents a relatively clean source of electric power with a low emission of greenhouse effect gases, any development in some areas is viewed with disfavor. In Puna, Hawail, native Hawailans and environmentalists object to potential emissions of hydrogen sulfide which amount to a small fraction of the natural emissions of this gas by Kilauea Volcano which dominates the landscape. There is also a problem with geothermal development in areas occupied by native Hawailan and other native Americans. Tribal religious rites may require the use of thermal features or be linked to lands surrounding geothermal developments. Developers at Beowowe, the Valles Caldera and Coso Hot Springs have encountered such conflicts between the religious practices of native Americans and the desire to exploit a natural resource. The Long Valley Caldera, an area of scenic beauty and high recreational use is now the scene of an ongoing battle between geothermal developers and the public perception of geothermal as noisy and ugly.

\subsubsection{Transmission access and integration}

Problems with access to transmission lines has resulted in several tactics by developers of geothermal resources. At Dixie 
Valley, oxbow Geothermal built their own transmission 1 ine to connect to lines tied to the lucrative southern california power market. Other areas such as Beowowe remain stalled as transmission capacity is negotiated. Some developers have marketed power to local municipalities or irrigation districts to avoid dealing with power wheeling agreements and utility tie-ins. In Hawaii, the feasibility was studied of constructing a deep underwater cable between the island of Hawait where potential for large scale production of geothermal power exists and the population centers on Maui and Oahu. The cable was found to be feasible and probably will be constructed.

Today power transmission cost and access to power markets remain a significant problem facing geothermal development. The cost of transmission and the resources most affected by transmission access should be studied as a further phase of this study.

\subsubsection{Utility/regulatory environment}

During the $70^{\prime} \mathrm{s}$ and early $80^{\prime} \mathrm{s}$ utilities offered standard contracts for purchase of geothermal power which encouraged active exploration. Tax incentives further promoted geothermal exploration and government funding of research to reduce the risks in geothermal development and improve technology spurred the construction of fields and power plants by oil companies and geothermal companies alike.

In the late $1980^{\prime} \mathrm{s}$ exploration has virtually come to a halt except for a few locations. Tax incentives have been withdrawn or reduced and falling oil and gas prices have encouraged utilities to use these fossil fuel resources. Given these constraints, the rate of exploration and development of geothermal resources is likely to continue at a low rate unless new incentives, access to markets and affirmative policies by utilities are adopted. The recent crisis in the Persian Gulf may result in some regulatory changes and utility attitude changes, but the long term affect of the recent political events on oil prices remains to be seen.

\section{Conclusions and Recommendations}

We conclude that a minimum of 27,400 MWe of geothermal power from hydrothermal sources will be available for development in the next 40 years. The majority of this power, 22,000 MWe, should cost less than $120 \mathrm{mils} / \mathrm{kw}-\mathrm{hr}$ to produce. Over 17,000 MHe would be available at less than $75 \mathrm{mils} / \mathrm{kw}-\mathrm{hr}$. Increased technology improvement could provide 20,000 MWe at less than $75 \mathrm{mils} / \mathrm{kw}-\mathrm{hr}$. If unidentified resources are included the total available resource base in 40 years is estimated at more than 50,000 MWe. Even at current technology levels this could mean 30,000 MWe at less than $75 \mathrm{mils} / \mathrm{kw}-\mathrm{hr}$. 
Political, environmental, regulatory, transmission access and market constraints will limit the supply of geothermal power. All of the constraints have been demonstrated to be amenable to reduction by regulatory change and government incentives. include:

Further study to improve the findings of this study should

1. Inclusion of advanced technologies such as Hot Dry Rock, Magma Energy and Geopressured Energy in the geothermal resource base. New developments in these technologies make updating of the resource base and calculation of cost to produce power important to our understanding of these resources.

2. Maintain the existing hydrothermal resource database and provide updates on a regular basis. The database gathered for this study includes information on resource temperature, well flowrates, depth to resource, current lease holders, development status, exploration status, contacts for information, resource size and date of last contact. It would be a fairly simple task to maintain this database and add new resources to it as information becomes available. Updates of the figures provided with this report could then be made on regular basis with little expense.

3. Integrate resource data with data on distance to transmission lines, size and capacity of transmission lines, costs for wheeling power, potential markets, power demand and price paid for power at nearest market.

4. In depth study of resources which are currently very expensive to produce because of depth, low temperature, low flowrate or other resource characteristic. The impact of technology improvement on these resources may be significant, bringing more resources into resource base and increasing our understanding of the shape of the cost/supply curve for geothermal resources. 


\section{BIBLIOGRAPHY}

Muffler, L. J. P., Editor, 1979, Assessment of Geothermal Resources of the United States - 1978, United States Geological Survey Circular 790, 163 pP.

White, D. E., and Williams, D. L., Eds., 1975, Assessment of Geothermal Resources of the United States - 1975, United States Geological Survey Circular 7.26, 155 pp.

Petty, Susan, Entingh, Dan, and Livesay, B. J., 1988, Impact of R\&D on Cost of Geothermal Power, Prepared for Sandia National Laboratory.

Bloomquist, R. G., Black, G. L., Parker, D. S., sifford, A., simpson, S. J., and street, L. V., 1985, Evaluation and Ranking of Geothermal Resources for Electrical Generation or Electrical Offset in Idaho, Montana, Oregon and Washington. Bonneville Power Administration, Vol. I \& II. 
TABLE 1

SIZE OF HYDROTHERMAL RESOURCES

Regions 6, 8-10, Identified Resources Only

\begin{tabular}{|c|c|c|c|}
\hline NAME OF RESOURCE & $\begin{array}{l}\text { MWe on } 1 \text { ine } \\
\text { by } 1995\end{array}$ & $\begin{array}{c}\text { Me in } 20 \\
\text { years }\end{array}$ & $\begin{array}{c}\text { MWe in } 40 \\
\text { Years }\end{array}$ \\
\hline GEYSERS & 1950 & 2000 & 2000 \\
\hline ROOSEVELT & 34 & 250 & 500 \\
\hline MEDICINE LAKE & 25 & 500 & 2000 \\
\hline DIXIE VALLEY & 62 & 250 & 500 \\
\hline CLEAR LAKE & 0 & 500 & 900 \\
\hline ISLAND PARK & 0 & 250 & 1000 \\
\hline 3 CREEKS BUTTE & 0 & 100 & 500 \\
\hline VALLES CALDERA & 0 & 250 & 1000 \\
\hline STEAMBOAT & 21. & 75 & 150 \\
\hline KLAKATH FAILS & 0 & 100 & 500 \\
\hline NEWBERRY & 0 & 100 & 1000 \\
\hline LONG VALLET (LT) & 30 & 250 & 500 \\
\hline BEOWOWE & 17 & 50 & 130 \\
\hline DESERT PEAK & 17 & 100 & 500 \\
\hline coso & 240 & 650 & 650 \\
\hline SALTON SEA & 219 & 500 & 1000 \\
\hline BRAFLEY & 0 & 150 & 300 \\
\hline RANDSBURG & 0 & 25 & 85 \\
\hline PUNA & 3 & 100 & 500 \\
\hline LONG VALLEY (HT) & 0 & 500 & 1600 \\
\hline EAST MESA & 220 & 360 & 360 \\
\hline HEBER & 92 & 250 & 250 \\
\hline COVE FORT & 11 & 150 & 500 \\
\hline COVE CREEK & 0 & 25 & 100 \\
\hline ALVORD DESERT & 0 & 100 & 200 \\
\hline SURPRISE VALLEY & 10 & 250 & 500 \\
\hline KILAUEA SW RIFT & 0 & 50 & 150 \\
\hline
\end{tabular}


SIZE OF HYDROTHERMAL RESOURCES

Regions 6, 8-10, Identified Resources OnIy

\begin{tabular}{|c|c|c|c|}
\hline NAME OF RESOURCE & $\begin{array}{l}\text { MWe on line } \\
\text { by } 1995\end{array}$ & $\begin{array}{c}\text { MWe in } 20 \\
\text { years }\end{array}$ & $\begin{array}{c}\text { MWe in } 40 \\
\text { Years }\end{array}$ \\
\hline POWER RANCHES & 0 & 190 & 475 \\
\hline LASSEN & 0 & 116 & 250 \\
\hline WESTMORELAND & 0 & 50 & 150 \\
\hline VALE & 2 & 425 & 1062 \\
\hline WUANITA & 0 & 205 & 515 \\
\hline MAGIC RESERVOIR & 0 & 360 & 900 \\
\hline WILBUR HS & 0 & 500 & 1500 \\
\hline MT. BAKER & 0 & 25 & 200 \\
\hline HOT SPRINGS RANCH & 0 & 540 & 1350 \\
\hline PARADISE HS & 0 & 25 & 100 \\
\hline RAFT RIVER & 0 & 30 & 195 \\
\hline ROUTT & 0 & 65 & 165 \\
\hline KELLY HS & 0 & 300 & 760 \\
\hline WENDELL & 0 & 250 & 650 \\
\hline RIO GRANDE RIFT & 0 & 120 & 300 \\
\hline SESPE HS & 0 & 125 & 330 \\
\hline GLAMIS & 0 & 275 & 680 \\
\hline BUCKEYE HS & 0 & 250 & 635 \\
\hline
\end{tabular}




\begin{tabular}{|c|c|c|}
\hline $\begin{array}{cc} & \text { SIZE OF } \\
\text { Regions } 6,8-10\end{array}$ & $\begin{array}{l}\text { HYDROTHERHAL RESOURCE } \\
\text { Accelerated Explora }\end{array}$ & In Case \\
\hline NAME OF RESOURCE & MWe in 20 Fears & MWe in 40 Years \\
\hline GEYSERS & 2000 & 2000 \\
\hline ROOSEVELT & 250 & 500 \\
\hline MEDICINE LAKE & 750 & 3000 \\
\hline DIXIE VALLEY & 250 & 500 \\
\hline CLEAR ILAKE & 500 & 900 \\
\hline ISLAND PARK & 500 & 2000 \\
\hline CRATER LAKE, 3 CREEKS AREA & 500 & 2000 \\
\hline VALLES CALDERA & 250 & 1000 \\
\hline STEAMBOAT & 300 & 600 \\
\hline KLAMATH FALLS & 500 & 2000 \\
\hline NEWBERRY & 250 & 1500 \\
\hline LONG VALLEY (LT) & 350 & 750 \\
\hline BEOWOWE & 150 & 250 \\
\hline DESERT PEAK & 250 & 1000 \\
\hline $\cos 0$ & 650 & 1000 \\
\hline SAITON SEA & 500 & 3000 \\
\hline BRAKLEY & 350 & 640 \\
\hline RANDSBURG & 100 & 250 \\
\hline PUNA & 200 & 1000 \\
\hline LONG VALIEY (HT) & 500 & 1600 \\
\hline EAST MESA & 360 & 500 \\
\hline HEBER & 250 & 500 \\
\hline COVE EORT & 300 & 1000 \\
\hline COVE CREEK & 200 & 300 \\
\hline ALVORD DESERT & 100 & 575 \\
\hline SURPRISE VALLEY & 500 & 1490 \\
\hline KILAUEA SW RIFT & 100 & 300 \\
\hline POWER RANCHES & 380 & 950 \\
\hline
\end{tabular}


SIZE OF HYDROTHERMAL RESOURCES

Regions 6, 8-10, Accelerated Exploration Case

\begin{tabular}{|c|c|c|}
\hline NAME OF RESOURCE & MWe in 20 Years & Mwe in 40 Years \\
\hline LASSEN & 100 & 350 \\
\hline WESTMORELAND & 150 & 1710 \\
\hline VALE & 850 & 2000 \\
\hline WUANITA & 410 & 1030 \\
\hline MAGIC RESERVOIR & 720 & 1800 \\
\hline WILBUR HS & 1000 & 2800 \\
\hline MT. BAKER & 50 & 400 \\
\hline HOT SPRINGS RANCH & 540 & 1350 \\
\hline PARADISE HS & 50 & 200 \\
\hline RAFT RIVER & 250 & 1000 \\
\hline ROOTT & 130 & 330 \\
\hline KELLY HS & 1180 & 3000 \\
\hline WENDELL & 250 & 650 \\
\hline RIO GRANDE RIFT $S$ & 240 & 600 \\
\hline SESPE HS & 250 & 660 \\
\hline GLAMIS & 275 & 680 \\
\hline BUCKEYE HS & 500 & 1270 \\
\hline
\end{tabular}


- Cost reporting year, average

1987.5

- Cost reporting year, vells

1990.5

- Cost reporting year, porer plant

1986.0

- Years to construct power plant

2.5

- Levelized annual Capacity Factor.

0.80

- Cost Basis: Orernight Construction, AFDC not included in nodel costs

- Allowance for interest during construction 1.081

- General and fuel inflation rate 0.06

- Discount rate $=$ Meighted cost of capital 0.1249 (For levelization in current \$.)

(For 1evel. in constant \$, use: 1 - (1.1249)/(1.06))

- Levelized Annual Capital Charge Rate for Calculations in Current Dollars

(Includes Anortization, Income Taxes, Tax Incentives, Property Tax, General Property Insurancel

- Current \$ Cost / Constant S Cost:

- General and fuel cost levelization factor

- Book life of project, years:

1.748

- Tax life:, years:

30

- Federal + State Income Tax Rate

15

- Investment Tax Credit Rate:

0.38

- Prop. Tax \& Insurance:

- Accounting Method: Nornalization

.02

- Accelerated Deprec.: Double Declining Balance

Geotheraal Production Field Special Financial Factors:

- Royalty Rate

- Severance Tax

- Percent Depletion allowance

- Intangible Iract. of Vell Cost 
"Imperial Valley - Flash

"Basin \& Range - Flash

"Cascades - Flash

$\because$ "Imperial Valley - Binary"

$\because$ "Basin \& Range - Binary "

"Young Volcanics - Flash 1": "Young Volcanics - Flash 2"

"IV-FL", "IV-BI", "BR-FL", "BR-BI"

"CS-FL", "CS-BI", "YV-FI", "YV-F2", "GY-DS"

1., "YES", "YES", "Energy in Region, MW*3OY "

$5750,1041,3060,1751,4559,51490.3250,3250,4000$

$-750,-41,-1500,-751,-1559,-48490,,-750,-750,-1500$

2., "YES", "NO", Energy in SubArea, Min*30Y"

$500,250,250,250,500,250,250,250,500$

"YES", "NO", "Wildeat success Rate $0, \quad 0, \quad 0$ $.20, .20, .20, .20, .20, .20, .20, .20, \quad .20$

$0, \quad 0, \quad 0,0, \quad 0, \quad 0, \quad 0, \quad 0, \quad 0$ "YES", "NO", "Confirmation Success Rate"

$.60, .60, .60, .60, .60, .60, .60, .60, .60$

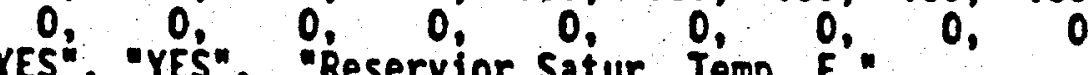

5., "YES", "YES", Reservior Satur. Temp, $F$ " "

$525,360,450,300,425,280,600,550,375$

$-25,-20,-50,-20,-50,-10,-25,-75, \quad-3$

5., "NO", "NO", "Resv. Temp at 10 Years, f"

$548,358,448,298,423,278,590,520,370$

$-10,-10,-10,-10,-10,-10,-10,-10,-10$

.. "YES", "YES", "Wellhead Temperature, F " 406,347 $-20,-20,-25,-10,-65,-10,-10,-31,-2$

"NO", "NO", "Wellhead Pressure PSIA" "3I, $380,500,225,500,225,500,166,235,100$ $-38,-50,-23,-50,-23,-50,-17,-24, \quad-10$

"NO", "NO", Wellhead Enthalpy, BTU/lb"

$419,340,375,280,366,260,900,370,1100$ $-42,-34,-38,-28,-37,-26,-90,-37,-110$

10., "NO"? "NO", "Non-Cond. Gases, PPM

$5000,1000,1000,2000,1000,1000,2000,1000,10000$

$15000,5000,5000,8000,1000,1000,700,200,10000$

11., "YES". "YES", "H2S, PPM

$50,0,10,0,0, \quad 0,1500 \quad 50,2000$

50, 50, 50, 200, 25, 25, 500, 75, 2500

12. "YES", "YES", "Tot, Dis. SOIIds, PPK

$250,5,1.5,1.2,1.0,0.5,15,10,0$

125, 1, 1.0, 1.3, 1.5, 0.5, 20, 5, 0

13. "YES". "NO", "Well Depth, 1000 Feet

$6, \quad 9,8,3,10,3,6,5,10$

4. NO" NO, O, O, $0, \quad 0, \quad 0, \quad 0, \quad 0$ $2600,2600,2600,1000,2600,1000,1320,2600,2600$

$0, \quad 0, \quad 0, \quad 0, \quad 0, \quad 0, \quad 0, \quad 0, \quad 0$

15. "YES", "YES", "Producer Redrill Fraction"

$.15, .10, .33, .20, .35, .20, \quad .35, \quad .20, \quad .35$

$.05, .05, .07, .05, .10, .05, .10, .05, \quad .10$

6. "YES", "YES", "Ory Holes per Producer

$.17, .17, .25, .17, .17, .17, \quad .20, .14, \quad .14$

$.03, .03, .08, .03, .33, .08, .13, .06, \quad .06$ 


\begin{tabular}{|c|c|c|c|c|c|c|}
\hline RESOURCE NAME & state. & $\begin{array}{c}\text { Cost in } \\
\mathrm{m} 118 / \mathrm{kw}-\mathrm{hr}\end{array}$ & $\begin{array}{l}\text { Not Mwo } \\
\text { in } 20 \text { yrs. }\end{array}$ & $\begin{array}{l}\text { Net MWo } \\
\text { in } 40 \text { yrs. }\end{array}$ & $\begin{array}{c}\text { Cumulative Mwo } \\
\text { In } 20 \text { yrs. }\end{array}$ & $\begin{array}{l}\text { Cumulative MWo } \\
\text { in } 40 \text { yrs. }\end{array}$ \\
\hline OEYSERS & ca & 26.00 & 2000.00 & 2000.00 & 2000 & 2000 \\
\hline ROOSEVELT & UT & 31.90 & 260.00 & 500.00 & 2260 & 2500 \\
\hline MEDICINE LAKE & CA & 37.20 & 750.00 & 3000.00 & 3000 & 5500 \\
\hline DIXIE VALLEY & nV & 37.70 & 250.00 & 500.00 & 3250 & 6000 \\
\hline CLEAA LAKE & CA & 38.80 & 500.00 & 900.00 & 3750 & 6900 \\
\hline ISLANO PARK & ID & 39.10 & 500.00 & 2000.00 & 4250 & 8900 \\
\hline 3 CREEKS BUTTE & OR & 39.30 & 500.00 & 2000.00 & 4750 & 10900 \\
\hline VALLES CALDERA & MM & 41.30 & 250.00 & 1000.00 & 6000 & 11900 \\
\hline STEAMBOAT & NV & 42.30 & 300.00 & 000.00 & 5300 & 12500 \\
\hline KLAMATH FALLS & OR & 42.70 & 500.00 & 2000.00 & 6800 & 14500 \\
\hline NEWBERRY & on & 43.90 & 250.00 & 1500.00 & 0050 & 16000 \\
\hline LONO VALLEY (LT) & ca & 44.70 & 350.00 & 760.00 & 6400 & 16750 \\
\hline BEOWOWE & nN & 46.80 & 160.00 & 250.00 & 0580 & 17000 \\
\hline DESERT PEAK & NV & 46.90 & 250.00 & 1000.00 & 6800 & 18000 \\
\hline $\cos 0$ & cA & 48.30 & 050.00 & 1000.00 & 7450 & 19000 \\
\hline SALTON SEA & CA & 48.30 & 500.00 & 3000.00 & 7950 & 22000 \\
\hline BRAMLEY & CA & 49.50 & 350.00 & 040.00 & 8300 & 22640 \\
\hline RANDSBURO & CA & 50.20 & 100.00 & 250.00 & 8400 & 22890 \\
\hline PUNA & HI & 80.70 & 200.00 & 1000.00 & 8000 & 23890 \\
\hline LONO VALLEY (HT) & CA & 52.20 & 500.00 & 1600.00 & 9100 & 25490 \\
\hline EAST MESA & CA & 52.20 & 360.00 & 500.00 & 9400 & 25990 \\
\hline HEBER & CA & 63.70 & 250.00 & 500.00 & 9710 & 26490 \\
\hline COVE FORT & UT & 54.90 & 300.00 & 1000.00 & 10010 & 27490 \\
\hline COVE CREEK & ID & 65.20 & 200.00 & 300.00 & 10210 & 27790 \\
\hline ALVORD DESERT & OR & 58.30 & 100.00 & 575.00 & 10310 & 28305 \\
\hline SURPRISE VALLEY & CA & 58.80 & 500.00 & 1490.00 & 10810 & 29855 \\
\hline
\end{tabular}




\begin{tabular}{|c|c|c|c|c|c|c|}
\hline \multicolumn{7}{|c|}{ GEOTHERMAL SITES RANKED BY COST TO PRODUCE POWER, UNIDENTIFIED RESOURCES INCLUDED } \\
\hline RESOURCE NAME & state & $\begin{array}{l}\text { Cost in } \\
m+1 \mathrm{e} / \mathrm{k} w-\mathrm{hr}\end{array}$ & $\begin{array}{l}\text { Net Mwo } \\
\text { in } 20 \text { yrs. }\end{array}$ & $\begin{array}{l}\text { Net Mwo } \\
\text { in } 40 \text { yre. }\end{array}$ & $\begin{array}{c}\text { Cumulative mwe } \\
\text { in } 20 \text { yrs. }\end{array}$ & $\begin{array}{c}\text { Cumulative MWe } \\
\text { in } 40 \text { yrs. }\end{array}$ \\
\hline KILAUEA SW RIFT & HI & 59.30 & 100.00 & 300.00 & 10910 & 30155 \\
\hline PONER RANCHES & $A Z$ & 61.30 & 380.00 & 960.00 & 11290 & 31105 \\
\hline LASSEN & CA & 01.90 & 100.00 & 350.00 & 11390 & 31455 \\
\hline WESTMORELAND & CA & 09.50 & 150.00 & 1710.00 & 11540 & 33165 \\
\hline VALE & OR & 70.70 & 860.00 & 2000.00 & 12390 & 35105 \\
\hline mUANITA & co & 76.30 & 410.00 & 1030.00 & 12800 & 36195 \\
\hline MAGIC RESERVOIR & 10 & 81.00 & 720.00 & 1800.00 & 13620 & 37995 \\
\hline WILBUR HS & CA & 93.70 & 1000.00 & 2800.00 & 14520 & 40795 \\
\hline MT. BAKER & wa & 98.00 & 50.00 & 400.00 & 14570 & 41195 \\
\hline HOT SPRINOS RANCH & nV & 102.00 & 840.00 & 1350.00 & 15110 & 42546 \\
\hline PARADISE HS & $c o$ & 109.60 & 50.00 & 200.00 & 15100 & 42745 \\
\hline RAFT RIVER & ID & 114.80 & 250.00 & 1000.00 & 15410 & 43745 \\
\hline ROUTT & co & 124.00 & 130.00 & 330.00 & 18540 & 44075 \\
\hline KELLY HS & CA & 141.60 & 1180.00 & 3000.00 & 16720 & 47075 \\
\hline WENOELL & CA & 149.00 & 250.00 & 050.00 & 16970 & 47728 \\
\hline RIO GRANDE RIFT 3. & $\mathrm{Mm}$ & 185.10 & 240.00 & 600.00 & 17210 & 48325 \\
\hline SESPE HS & CA & 172.50 & 250.00 & 000.00 & 17460 & 48985 \\
\hline GLAMIS & CA & 172.60 & 275.00 & 080.00 & 17735 & 49605 \\
\hline BUCKEYE HS & cA & 240.30 & 500.00 & 1270.00 & 18235 & 50935 \\
\hline
\end{tabular}


TABLE 6

CURRENT POWER PRODUCTION

THE GEYSERS, CALIFORNIA

\begin{tabular}{|c|c|c|c|c|}
\hline POUEA PRODUCER & \multirow{2}{*}{$\begin{array}{l}\text { STEAM } \\
\text { SUPPLER }\end{array}$} & \multirow{2}{*}{$\begin{array}{l}\text { PLANT } \\
\text { OWNER }\end{array}$} & \multirow{2}{*}{$\begin{array}{l}\text { RATED } \\
\text { CAPACITY } \\
\text { MWe }\end{array}$} & \multirow{2}{*}{$\begin{array}{l}1990 \text { AVE. } \\
\text { GENERATED } \\
\text { MWe }\end{array}$} \\
\hline UNIT & & & & \\
\hline \multicolumn{5}{|l|}{ Pate $202-3$} \\
\hline Units $1-12$ & UNOCAL & PG\&E & 608 & \\
\hline Units $13 \& 16$ & Calpine & PG\&E & 246 & \\
\hline $\begin{array}{l}\text { West Ford Flat } \\
\text { Bear Creek Cyn. } \\
\text { Jos. W. Aidlin } \\
\end{array}$ & Calpine & Calpine & 67 & \\
\hline Subtotal PG\&E & . & & (2. & $12=208809$ \\
\hline \multicolumn{5}{|l|}{ Dopt. Veter nes? } \\
\hline Bottlerock & DWR & DWR & 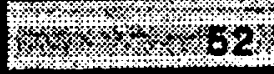 & 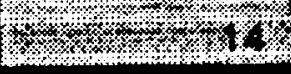 \\
\hline \multicolumn{5}{|l|}{ Mer } \\
\hline GEO $1 \& 2$ & GEO & NCPA/GEO & 220 & 150 \\
\hline Santa $\mathrm{Fe} 1$ & Santa Fe & Santa $\mathrm{Fe}$ & 80 & 70 \\
\hline Subtotal NCPA & & & $\sqrt{2} \times 2 \times-200$ & 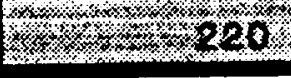 \\
\hline \multicolumn{5}{|l|}{ SVub : } \\
\hline GEO 1 & GEO & SMUD/GEO & 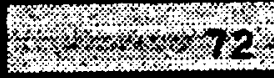 & $6+2 \times 3 \times 60$ \\
\hline \multicolumn{5}{|l|}{$\mathrm{CopA}$} \\
\hline Coldwater $\mathrm{cr}$. & GEO & CCPA/GEO & 130 & 65 \\
\hline TOTAL GEYSERS & & & $2.1 \% \div \div=1948$ & 8.1954: \\
\hline
\end{tabular}


TABLE 7

CURRENT POWER PRODUCTION

CALIFORNIA NON-GEYSERS

\begin{tabular}{|c|c|c|c|c|c|}
\hline 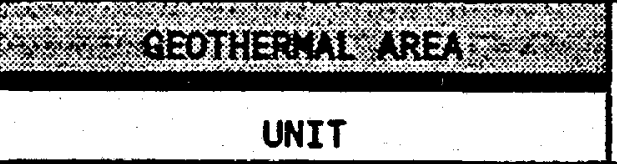 & $\begin{array}{c}\text { POWER } \\
\text { PURCHASER }\end{array}$ & $\begin{array}{l}\text { STEAM (HEAT) } \\
\text { SUPPLIER }\end{array}$ & $\begin{array}{l}\text { RATED } \\
\text { CAP. } \\
\text { MWE }\end{array}$ & $\begin{array}{l}1990 \\
\text { AVE. } \\
\text { MWe }\end{array}$ & $\begin{array}{l}\text { Cap. } \\
\text { Factor } \\
x\end{array}$ \\
\hline \multicolumn{6}{|l|}{ coso } \\
\hline Navy 1 , Unit 1, $2 \& 3$ & SCE & CA Energy & 88 & 80 & \\
\hline BLM, East \& West & SCE & CA Energy & 88 & 80 & \\
\hline Navy 2 & SCE & CA Energy & 88 & 80 & \\
\hline 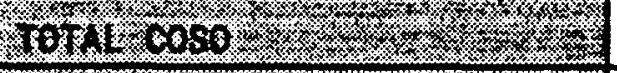 & & & 282600 & 240 & \\
\hline EAST) ESA & & & & & 90 \\
\hline BC McCabe & SDG\&E & Magma & 13.4 & 12.5 & \\
\hline ORMESA I, II \& IE & SCE & ORMAT & 68 & 60 & \\
\hline GEM $1,2 \& 3$ & SCE & GEO/Misston & 47 & & \\
\hline Heber - Binary & SDG\&E & Chevron & 45 & 0 & \\
\hline Heber - Flash & SCE & Chevron & 47 & 39 & \\
\hline - & & & $x+20 \%$ & & \\
\hline \multicolumn{6}{|l|}{ 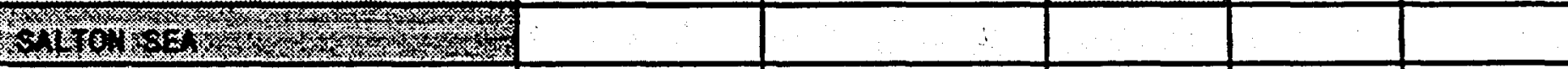 } \\
\hline CEP Unit 1 & SCE & UNOCAL & 11 & 8 & 80 \\
\hline Unit $\# 2$ (Unit 1 add on) & SCE & UNOCAL & 20 & 18 & $\begin{array}{c}118 \\
\text { Contract } \\
15.5 \mathrm{MW} \\
\end{array}$ \\
\hline Unit 13 & SCE & UNOCAL & 53 & 50 & $\begin{array}{r}106 \\
\text { Contract } \\
47.5 M W \\
\end{array}$ \\
\hline Del Ranch & SCE & Red HAll & 34 & & \\
\hline Elmore $\$ 1$ & SCE & Red Hill & 34 & & \\
\hline Leathers 1 & SCE & Red HIII & 34 & & \\
\hline Vulcan & SCE & Red $\mathrm{H} 111$ & 34 & & \\
\hline 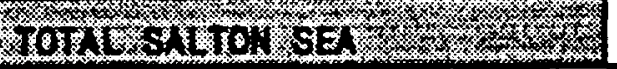 & & & 21000 & & \\
\hline
\end{tabular}




\begin{tabular}{|c|c|c|c|c|c|}
\hline 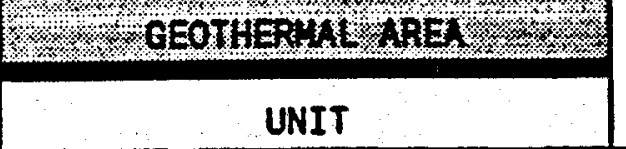 & $\begin{array}{l}\text { POWER } \\
\text { PURCHASER }\end{array}$ & $\begin{array}{l}\text { STEAM (HEAT) } \\
\text { SUPPLIER }\end{array}$ & $\begin{array}{l}\text { RATED } \\
\text { CAP. } \\
\text { HWE }\end{array}$ & $\begin{array}{l}1990 \\
\text { AVE. } \\
\text { MWe }\end{array}$ & $\begin{array}{l}\text { Cap. } \\
\text { Factor } \\
x\end{array}$ \\
\hline 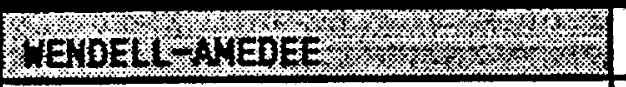 & & & & & \\
\hline $\begin{array}{l}\text { Honey Lake - Wood/ } \\
\text { Geothermal hybrid }\end{array}$ & PG\&E & Geoproducts & 30 & & \\
\hline Amedee & PG\&E & $\begin{array}{c}\text { Amedee } \\
\text { Geothermal }\end{array}$ & 2 & & \\
\hline Wineagle: & PG\&E & Wineagle & 1 & & \\
\hline 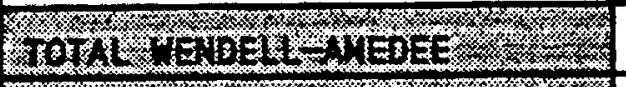 & & & 2 & & \\
\hline 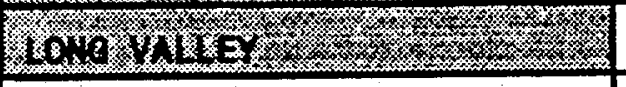 & & $\therefore$ & & & \\
\hline Casa Diablo & SCE & $\begin{array}{l}\text { Mammoth- } \\
\text { Pactfle }\end{array}$ & 12 & & \\
\hline 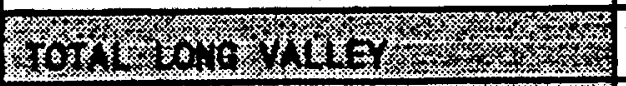 & & & 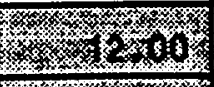 & & \\
\hline 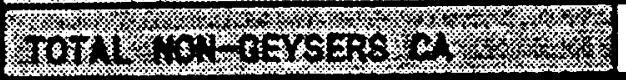 & & & 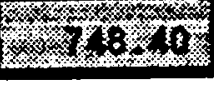 & & \\
\hline
\end{tabular}


TABLE 8

CURRENT POWER PRODUCTION

WESTERN STATES EXCLUSIVE OF CALIFORNIA

\begin{tabular}{|c|c|c|c|c|c|}
\hline $\begin{array}{c}\text { UNIT } \\
\text { UNT }\end{array}$ & $\begin{array}{c}\text { POWER } \\
\text { PURCHASER }\end{array}$ & $\begin{array}{l}\text { STEAM } \\
\text { (HEAT) } \\
\text { SUPPLIER }\end{array}$ & $\begin{array}{l}\text { RATED } \\
\text { CAP. } \\
\text { MWE }\end{array}$ & $\begin{array}{l}1990 \\
\text { AVE. } \\
\text { MHe }\end{array}$ & $\begin{array}{l}\text { Cap. } \\
\text { Factor } \\
x\end{array}$ \\
\hline \multicolumn{6}{|l|}{ 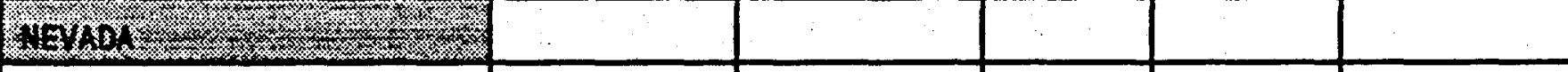 } \\
\hline Dixte Valley & SCE & Oxbow & 62 & 56 & $\begin{array}{c}111 \\
\text { Contract } \\
49.5 \mathrm{MW}\end{array}$ \\
\hline Beowowe & SCE & $\begin{array}{c}\text { Crescent } \\
\text { Valley/ } \\
\text { Oxbow } \\
\end{array}$ & 16.5 & 13 & 96 \\
\hline Desert Peak & $\begin{array}{l}\text { Sterra } \\
\text { Pactfic }\end{array}$ & Cal Energy & 9 & & 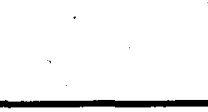 \\
\hline San Enidio Desert & $\begin{array}{l}\text { Sterra } \\
\text { Pactfic }\end{array}$ & ORMAT & 3 & & . \\
\hline stlllwater & $\begin{array}{l}\text { Sterra } \\
\text { Pactfic }\end{array}$ & ORMAT & 3 & & \\
\hline Soda Lake & $\begin{array}{l}\text { Sterra } \\
\text { Pactfic }\end{array}$ & ORMAT & & 13 & \\
\hline Brady Hot Sprs. & $\begin{array}{l}\text { Sierra } \\
\text { Pactfic } \\
\end{array}$ & & 5 & 0 & $\begin{array}{c}\text { Contract } \\
\text { Defauit }\end{array}$ \\
\hline \multicolumn{6}{|l|}{ Steamboat } \\
\hline Geo $1 \& 1 A$ & $\begin{array}{l}\text { Sierra } \\
\text { Pacific }\end{array}$ & ORMAT & 7 & $\cdot$ & \\
\hline Yankee/Calthness & $\begin{array}{l}\text { Sierra } \\
\text { Pacific }\end{array}$ & & 12 & 11 & \\
\hline 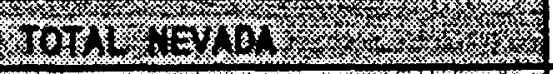 & & & 117.50 & & \\
\hline \multicolumn{6}{|l|}{ W. } \\
\hline Cove Fort - Unit $\$ 1$ & $\begin{array}{l}\text { Provo/ } \\
\text { UMPA }\end{array}$ & $\begin{array}{l}\text { Mother } \\
\text { Earth }\end{array}$ & 3 & & \\
\hline Stean & 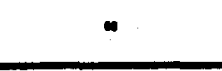 & $\cdots$ & 2 & & \\
\hline Unit $: 2$ & $\cdots$ & $\cdots$ & 7 & 11 & \\
\hline
\end{tabular}




\begin{tabular}{|c|c|c|c|c|c|}
\hline $\begin{array}{l}\text { SEOHEWII U ARE } \\
\text { UNIT }\end{array}$ & $\begin{array}{c}\text { POWER } \\
\text { PURCHASER }\end{array}$ & $\begin{array}{l}\text { STEAM } \\
\text { (HEAT) } \\
\text { SUPPLIER }\end{array}$ & $\begin{array}{l}\text { RATED } \\
\text { CAP. } \\
\text { MHE }\end{array}$ & $\begin{array}{l}1990 \\
\text { AVE. } \\
\text { MWe }\end{array}$ & $\begin{array}{l}\text { Cap. } \\
\text { Factor } \\
x\end{array}$ \\
\hline Roosevelt & $\begin{array}{l}\text { Utah } \\
\text { Power }\end{array}$ & Cal Energy & 34 & & \\
\hline 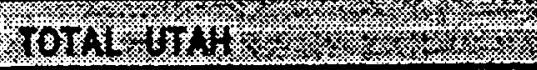 & & & 46.00 & & \\
\hline 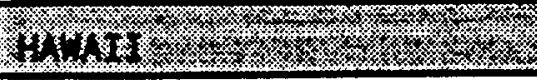 & & & & & \\
\hline Puna & HECO & ORMAT & 36 & 30 & Aprt1, '91 \\
\hline Puna & HECO & UH/DOE & 3 & 0 & $\begin{array}{c}\text { Off Line Env. } \\
\text { Problems }\end{array}$ \\
\hline 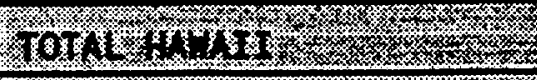 & & & 3., 01 & & \\
\hline 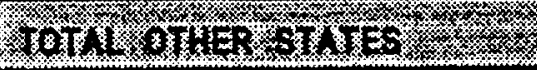 & & & 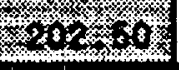 & & \\
\hline
\end{tabular}




\section{SUPPLY OF GEOTHERMAL POWER AT COST}

Regions 6, 8-1 0 current technology, identified resources only.

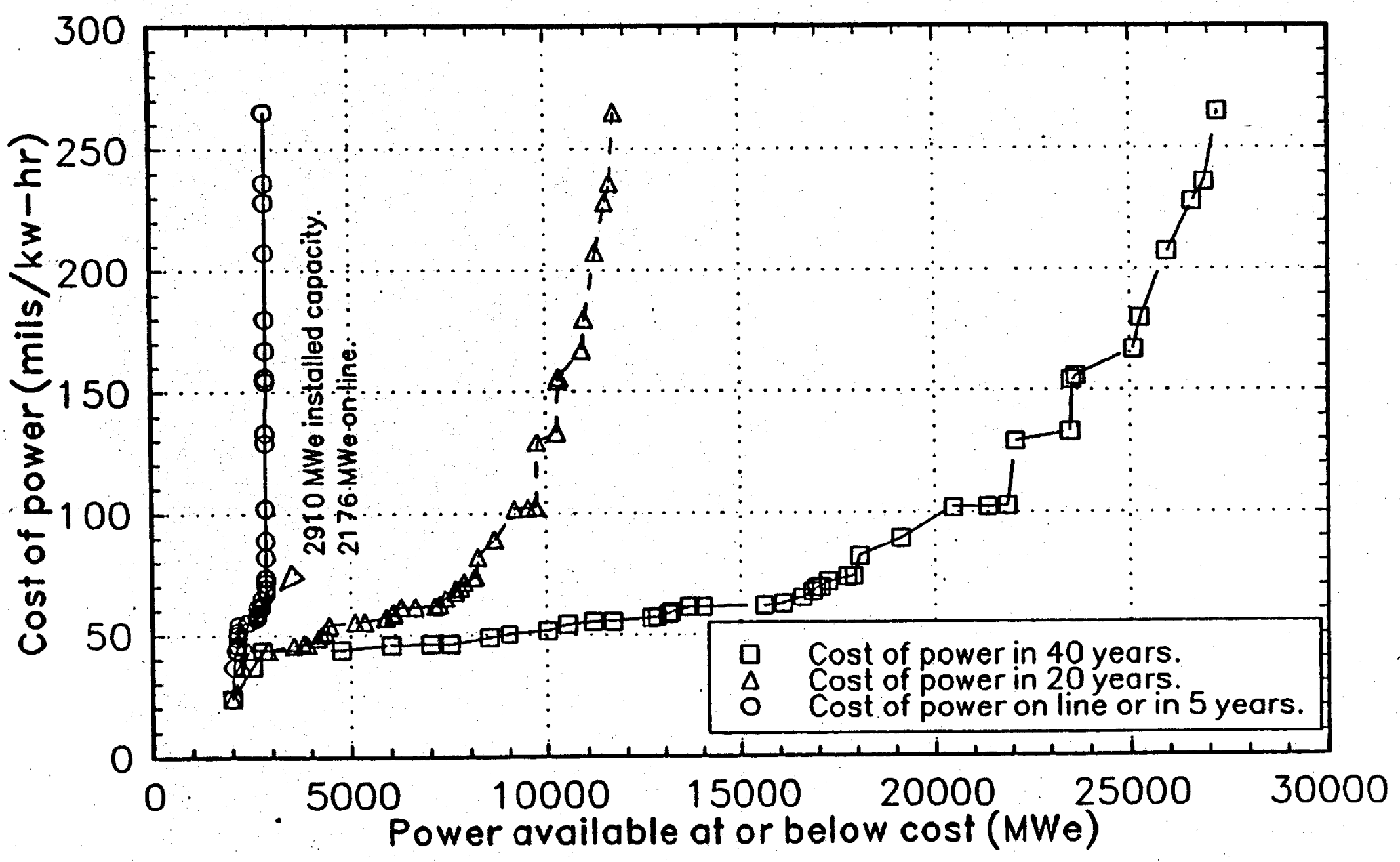




\section{SUPPLY OF GEOTHERMAL POWER AT COST}

Regions 6, 8-10, current technology, unidentified resources included.

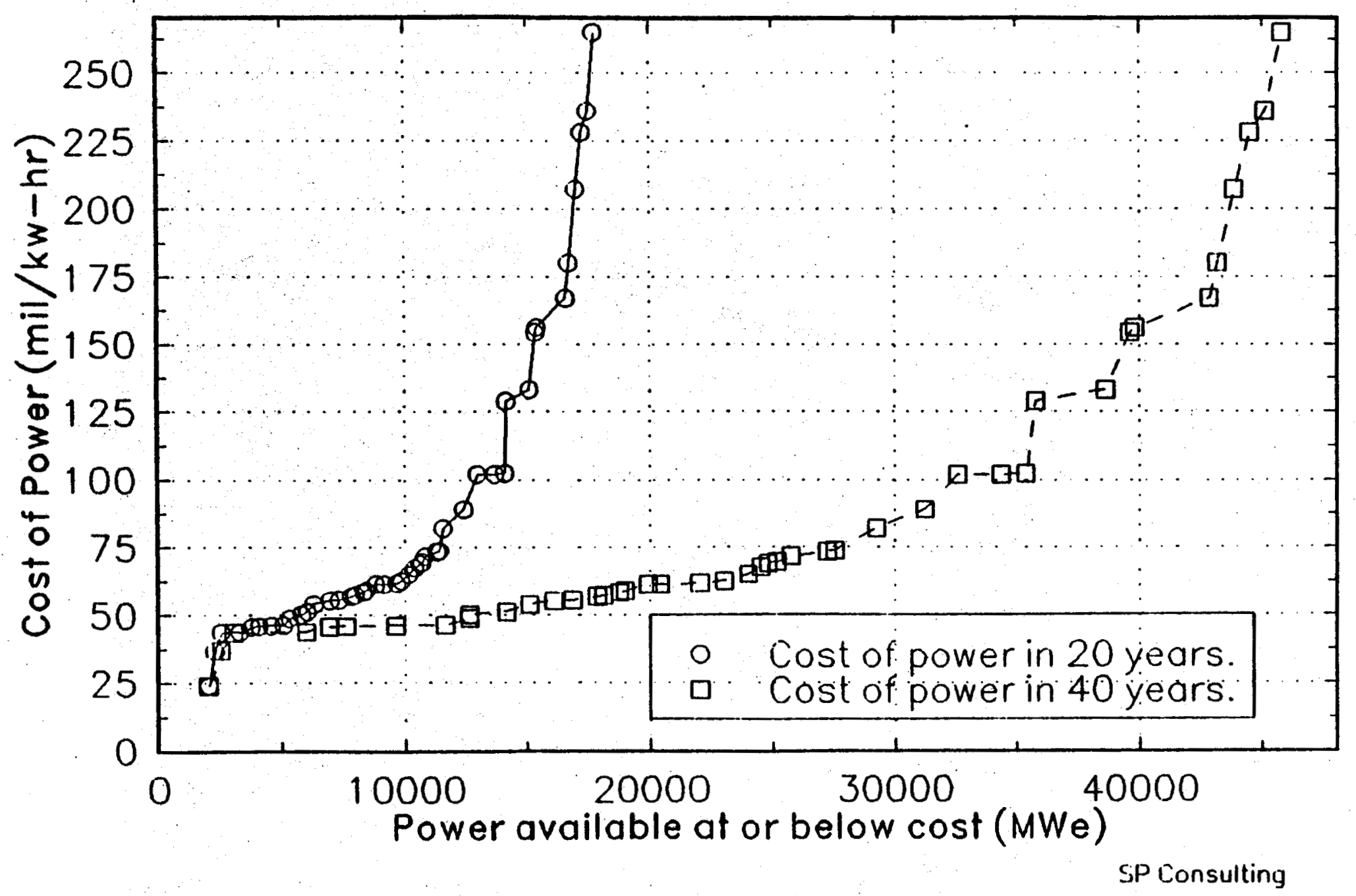




\section{SUPPLY OF GEOTHERMAL POWER AT COST}

Regions 6, 8-10, increased technology, identified resources only.

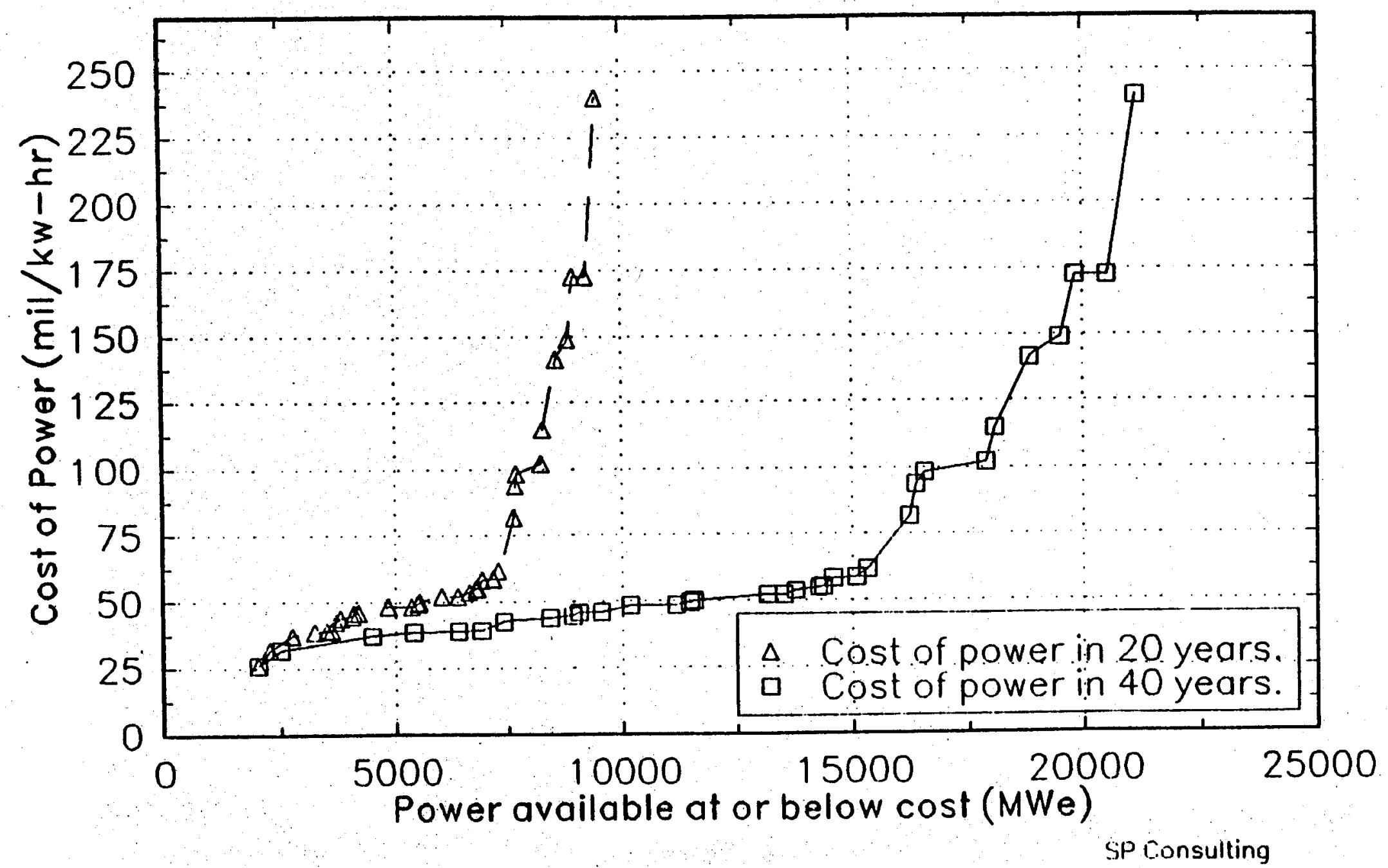




\section{SUPPLY OF GEOTHERMAL POWER AT COST}

Regions 6, 8-10, increased technology, unidentified resources included.

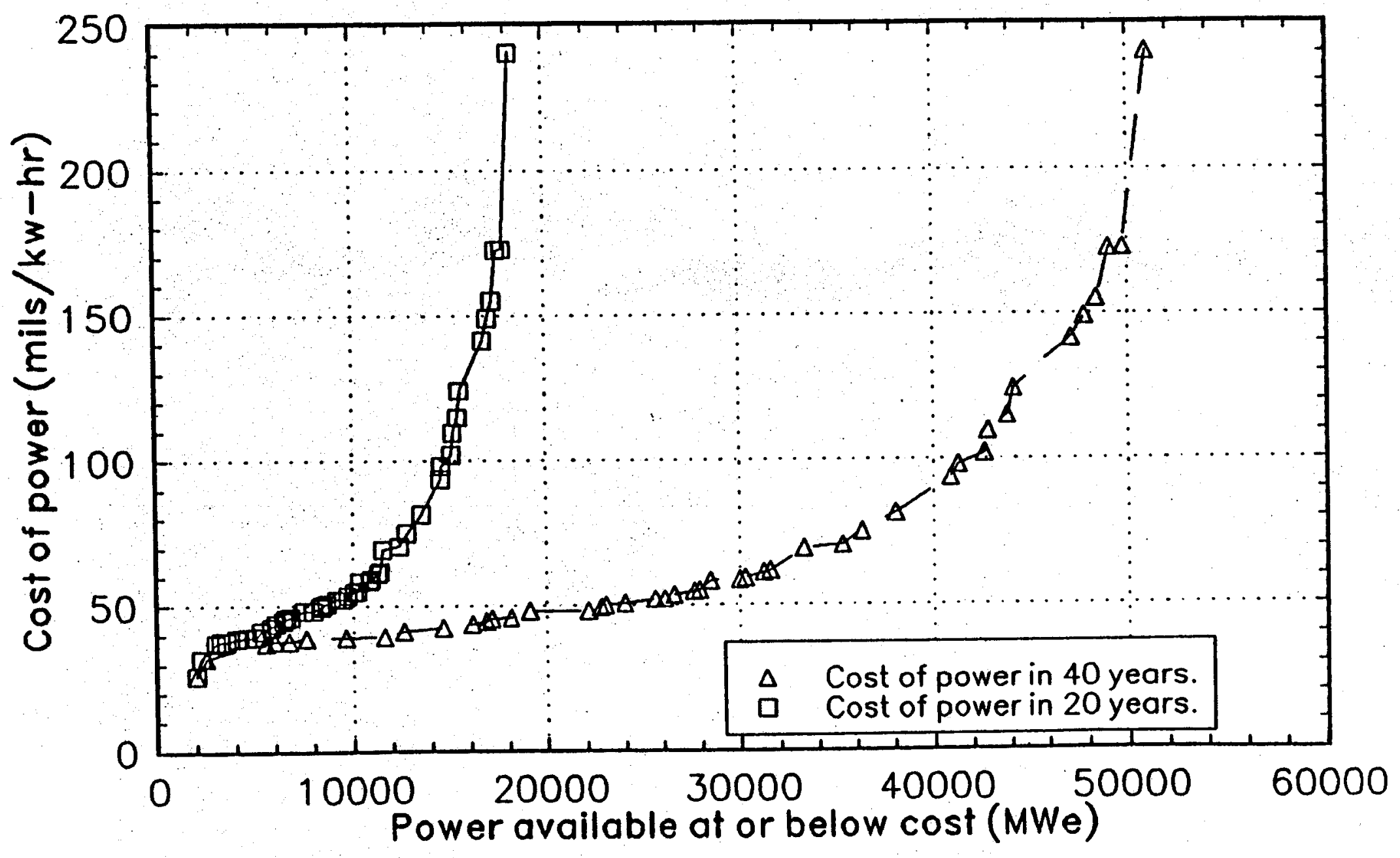




\section{GEOTHERMAL SUPPLY ENVELOPE 20 YEAR SUPPLY CURVE}

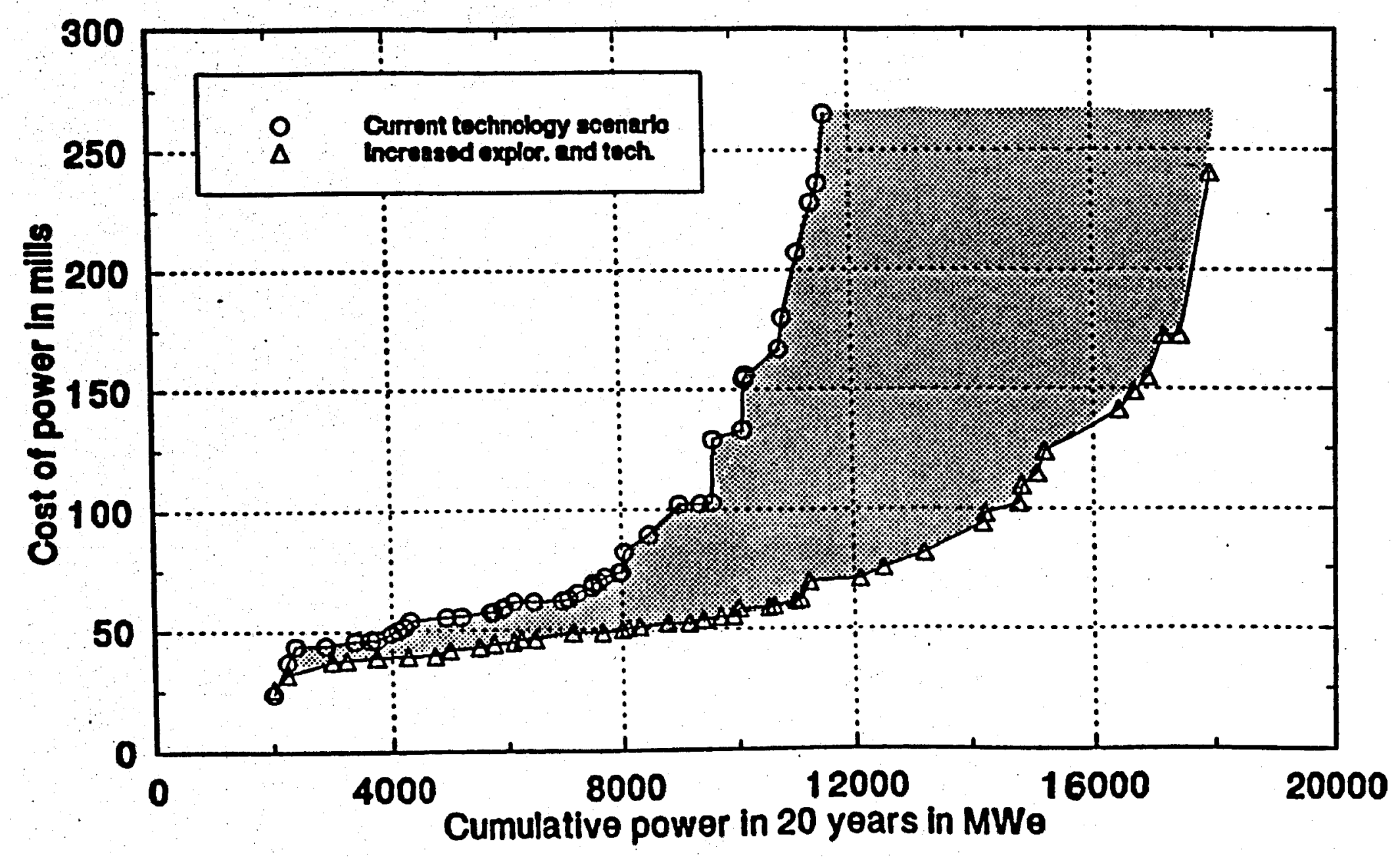




\section{GEOTHERMAL SUPPLY ENVELOPE 40 YEAR SUPPLY CURVE}

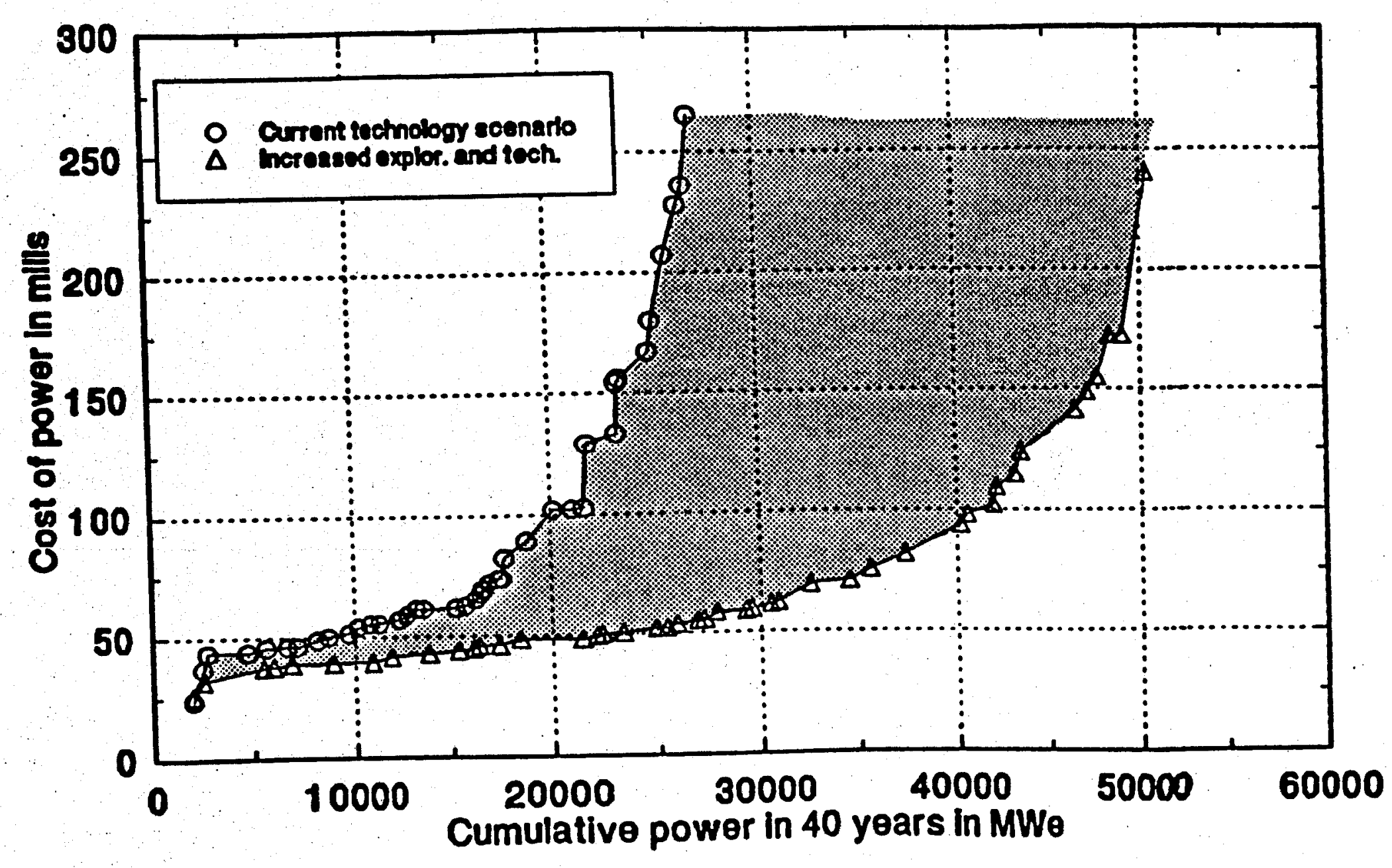


FIGURE 7

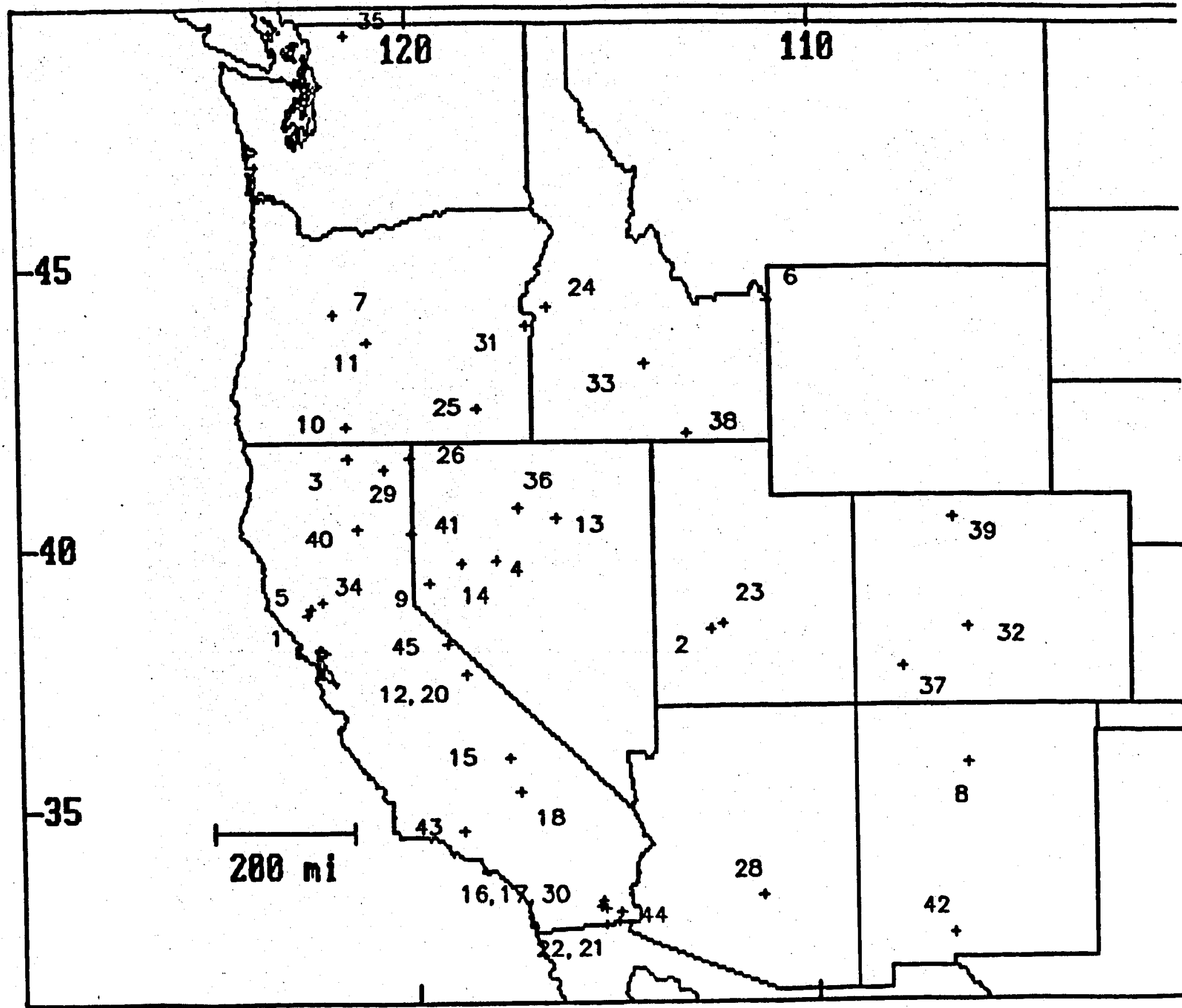

CLEAR LAKE

ISLAND PAFK

3 CREEKS EUTTE

valies caloera

STEAMEOAT

KLAMATH Falls

NEWBERPY

LONG VALLEY (LT)

BEONOWE

DESERT PEAK

coso

SALTON SEA

ERAIILY

Randoseuta

Puna

LONG MALEY (HT)

EAST MESA

HEBER

COVE FORT

COVE CREEX

ALVORD DESERT

SUPORISE YALLEY

KILANEA SW RIFT

POWER PANCHES

LASSEN

WESTMORELAND

VALE

MANITA

MAIC RESERVIIA

WILER hS

MT EAKER

HOT SPRINGS RANOH

PAPADISE HS

RAFT RIVER

ROUTT

KELLY HS

WENDELL

RIO CRANDE RIFT S.

SESPE HS

GLAMIS

EUCKEYE HS 
APPENDIX A 
RESUME

SUSAN PETTY

EXPERIENCE SUMMARY:

Petty brings a unique combination of geology, field drilling involvement and general geothermal knowledge. Her experience bridges the gap between geology and engineering. She has been involved in fluid flow in a porous media for 15 years with her geothermal experience from the hydrology view point as well as the reservoir engineering view point. She has varied experience in waste monitoring and waste disposal design and analysis.

\section{EMPLOYMENT EXPERIENCE:}

1984 to present CONSULTANT

Performed reservoir analysis of Niland and other geothermal resources. Planned well tests for Coso geothermal resource. Provided technical consulting on instrument development and testing. Assisted in instrument test and evaluation at the deep Salton Sea test well.

1981 to 1984 WELL PRODUCTION TESTING, Carlsbad CA

Reservoir Engineering Manager and Secretary/Treasurer-Managed reservoir assessment projects in geothermal and oil and gas areas. Planned and carried out geothermal well tests and reinjection well tests. Supervised collection of reservoir data and performed analysis for resource evaluation. Performed technical analysis of fracture stimulation at Fenton Hill and North Sea reservoirs.

1979 to 1981 EG\&G IDAHO, Idaho Fal18

Project Manager and Senior scientist Geothermal Reservoir Engineering-Provided management and planning of geothermal well testing at the Raft River Geothermal Project. Collected and analyzed well test data. Wrote procedures for test operation. planned and managed national programs studying reservoir engineering methods for low to moderate temperature geothermal systems and the movement of injected fluid in fractured rock. Provided technical assistance for the testing of small to large geothermal wells in Utah, Idaho, Colorado, Montana, California (Geysers, Coso Hot Springs, Imperial Valley) and British Columbia. Performed technical analysis on fracture stimulation projects at Raft River.

1976 to 1979 UNIVERSITY OF HAWAII WATER RESOURCES RESEARCH CENTER Research Assistant-Assessed problems of injection wells in Hawai for state of Hawail, Department of Natural Resources. Wrote numertcal model to simulate waste water injection wel1s. Assessed potential.for recharge to Hawail Geothermal Project we 11 at Puna, 
Hawait.

1976 to 1979 CONSULTANT

Geohydrology-supervised and analyzed well testing in Maryland. Investigated movement of radionuclides through groundwater on Enewetak Atoll including drilling and testing of monitor wells for Department of Energy and the Department of Defense. Assessed potential for groundwater contamination from surface sources in the Trust Territories of the Pacific Islands for the Environmental Protection Agency.

1975 to 1976 DELAWARE GEOLOGICAL SURVEY, Newark, De laware Lead Project Geologist-Carried out project to assess groundwater resources of northern Delaware including extent of water bearing formation and recharge to aquifers. Supervised two geologist and a drilling crew. Planned and drilling and testing of 58 wells in northern Delaware.

1973 TO 1974 GEOLOGIST FOR ENVIRONMENTAL CONCERN, Mary 1 and Geologist- Assessed environmental impact on ground and surface waters associated with development projects in the wetlands

ASSOCIATIONS, MEMBERSHIPS, PUBLICATIONS

Is a member of Geothermal Resources Council and the society of Petroleum Engineers. Has authored papers on ground water hydrology, geothermal reservoir analysis, reservoir testing and waste injection problems.

EDUCATION:

B A, Geology, Princeton University, 1973

$M$ A, Hydrology, University of Hawail, 1980

Additional training in Management skilis Development and Petroleum Orifling Technology 
RESUME

DR. BILL LIVESAY

EXPERIENCE SUMMARY:

Over 20 years experience in design and technology of drilling methods gained through industrial consulting as user, builder and researcher of equipment and instrumentation. Has been involved in the development of new technology in the geothermal area through long term association with Sandia Labs.

EMPLOYMENT EXPERIENCE

1977 to Present: LIVESAY INC.

Principal consultant--Managed development program for mud pulse MWD system for AMF/Scientific Drilling Inc., bringing together numerous consultants and contractors to build state-of-the-art prototype which was successful in the field. Has worked with the DOE and Sandia National Laboratories in geothermal equipment, instrumentation, wel1 design, geothermal well cost models, program development and project review. Taught courses for AMOCO in drilling optimization, deviation control and directional drilling.

1974 to 1977: KENNECOTT COPPER COMPANY, San Diego Managing Director, Manganese Nodule Mining Program--Managed program for ocean mining of manganese nodules. Responsible for staff of 140 involved in development of technology, design of equipment and instrumentation, program control of construction and operations for port facility, transport vessels, mining ship, subsea mining equipment and marine geology.

1972 to 1974 : DRESSER INDUSTRIES, Da11as Manager of Research-Developed drill bits, drilling tools and driliing equipment, special lubricants, bearing materials and seals. Provided analytical support and in-house consulting for other divisions of Dresser.

1967 to $1972:$ UNIVERSITY OF TULSA

Professor of Petroleum and Mechanical Engineering and Director of the Driling Research Projects-Directed cooperative research program in drilling and rock mechanics, researching drilling and off-shore operations, rock mechanics and structure analysis. served as industrial consultant in drilling operations, orilling and offshore technology.

1964 to 1967 : ESSO PRODUCTION RESEARCH, Houston

Senior Research Engineer--Performed $R$ \& $D$ work in drilling and offshore structures, platform response and floating drili ing vessel structural design and analysis. Worked in the drilling 
optimization task force group.

ASSOCIATIONS, MEMBERSHIPS, PUBLICATIONS

Is a member of SPE and ASME. Has also been on various advisory boards and panels for Sandia, Los Alamos, the Marine Board of the National Academy of Engineering and others. Has authored 8 papers on various aspects of drilling equipment and procedures.

EDUCATION

BS ME, OKlahoma State University, 1960

PHD ME, Kansas State University, 1966 


\section{RESUME \\ WILLIAM P. LONG, Ph.D \\ MINERAL ECONOMIST AND CHEMICAL ENGINEER}

PROFESSIONAL EXPERIENCE Corporate and project evaluations, planning and forecasting, marketing, acquisitions, financing, financial reporting, project engineering and environmental protection.

1987 - Present Associate Mineral Economist and Engineering Consultant, Cascadia Exploration Corporation; President, Carlin Gold Company

Assisted clients with geothermal acquisitions. Advised a client in structuring an audit with regard to a major lawsuit against an operating partner. Provided market analyses for clients in the geothermal business. Assisted with the preparation of documents and the sale of publicly traded securities. Provided mineral property land status reports for clients. Arranged acquisitions and sale of precious metal properties. Supervised evaluation and drilling of a gold property.

1980-1986 Executive Vice President and Chief Financial Officer, Thermal Exploration Company

Reviewed and negotiated many joint venture opportunities including a geothermal exploration services agreement with $A M A X$ Exploration and a multi million dollar geothermal joint venture with a major oil company. Served on the technical committee and reviewed the operator's proposals for the development of the Roosevelt Hot springs Geothermal field. provided merger and acquisition evaluations and negotiated such arrangements. Analyzed numerous projects in minerals, geothermal, ofl and gas. Assumed total responsibility for geothermal marketing and negotiated with sierra Pacific Power Company to arrange a transmission path from the Beowowe Geothermal Unit in Nevada to Southern California Edison. Prepared business plans, financial forecasts and annual reports for the corporation. Supervised all legal, financial and engineering work. Negotiated a merger in 1984 of O'Brien Resources Corporation and Thermal Exploration Company. 
1978-1980 Business Manager - Geothermal. Div., AMAX Exploration, Inc.

Pursued geothermal business opportunities and coordinated all business activities. Assisted the firm's attorneys in contract preparation and negotiated appropriate contracts. Overall responsibility for the office, accounting, land records, permitting and marketing. Determined the need for and defined the scope of engineering, feasibility, financial, and legislative studies.

1976-1978 Systems Engineer and Business Analyst - Geothermal Div., AMAX Exploration, Inc.

Assisted in negotiating many major joint venture and acquisition agreements including the purchase of Phillips Petroleum's phosphate property in Florida. Provided business, economic and engineering guidance to the geothermal group. supervised and developed financial and economic studies on a variety of mineral and geothermal projects.

1974-1976 Systems Engineer, AMAX Exploration, Inc.

Provided financial and economic analysis of various projects and joint ventures. Mineral projects analyzed included specific property evaluation for: gold, silver, platinum, lead, zinc, molybdenum, copper, trona, clay, phosphate, coal, iron, 1 imestone and uranium.

1970-1971 Lieutenant - Operations Officer, 544th Construction support, Vietnam, U.S. Army Corps of Engineers

Assumed operating responsibility for a large rock quarry and an asphalt production facility. Managed three waste water treatment facilities at Fort Benning, Georgia.

\section{ACADEMIC BACKGROUND}

Professional Degree (1969) Chemical and Petroleum Refining Engineering, Colorado School of Mines

Ph.D (1974) Mineral Economics, Colorado school of Mines.

\section{PROFESSIONAL AFFILIATIONS}

American Institute of Chemical Engineers

Society for Mining, Metallurgy, and Exploration, Inc. Geothermal Resources Council 
APPENDIX B 
CURRENT TECHNOLOGY 
GEOTHERMAL COST OF POWER ESTIMATE Base Case Costs: Imperial Valley - Salton

RUN: $08-01-1990-13: 30: 44$

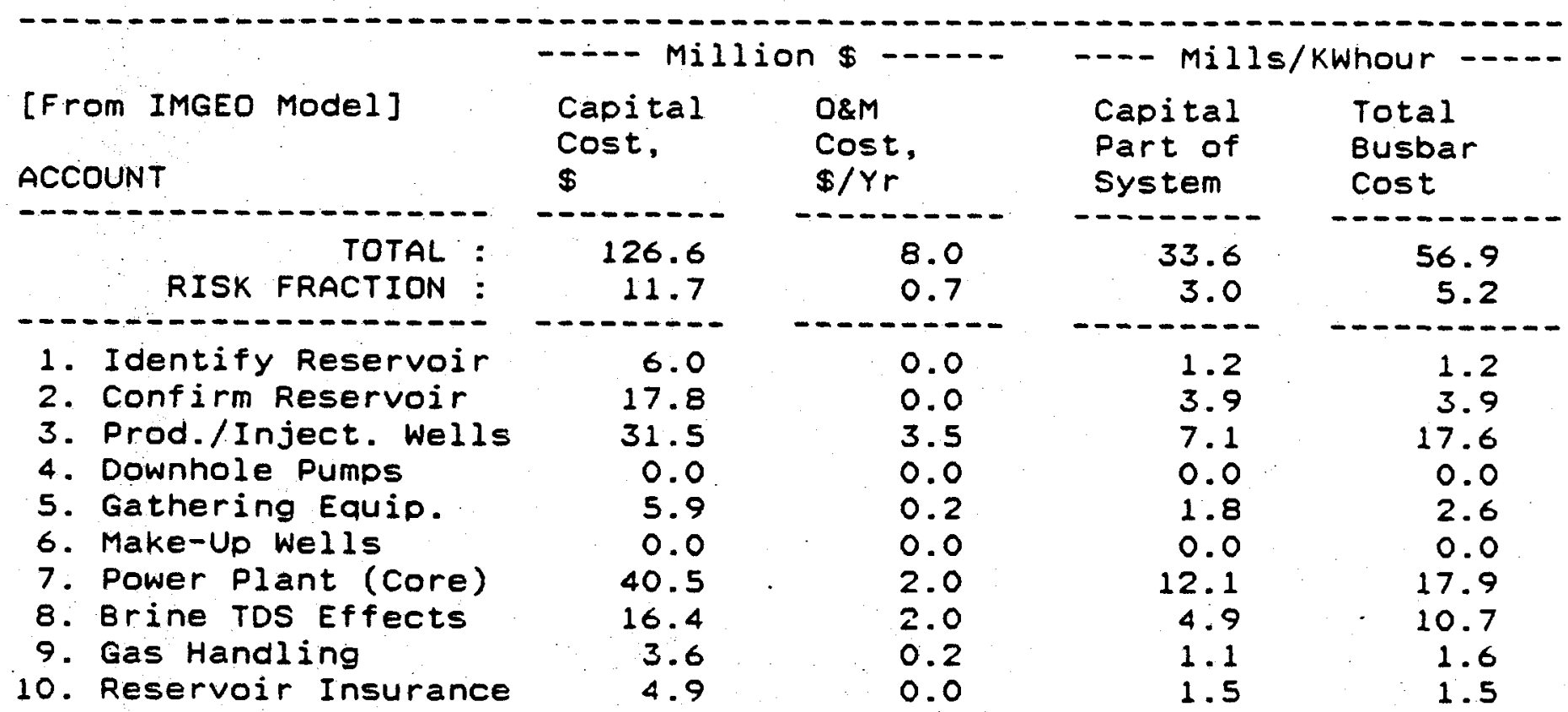

IM-GEO: SENSITIVITY FACTORS IN EFFECT 08-01-1990-13:30:44

R\&D Achumt: BINARY Plant - Capital cost : 0.76

Regional Weights = Regional Capacity

(End of Page)

GEOTHERMAL COST OF POWER ESTIMATE RUN: 08-01-1990 - 13:30:44 Base Case Costs: Imperial Valley - Heber

[From IMGEO MOdel]

ACCOUNT

- - - - - - - - - - - - - - - -

TOTAL:

RISK FRACTION :

1. Identify Reservoir

2. Confirm Reservoir

3. Prod./Inject. Wells

4. Downhole Pumps

5. Gathering Equip.

6 . Make-Up Wells

7. Power Plant (Core)

8. Brine TDS Effects

9. Gas Handling

10. Reservoir Insurance

\begin{tabular}{|c|c|}
\hline $\begin{array}{l}\text { Capital } \\
\text { Cost, } \\
\$\end{array}$ & $\begin{array}{l}\text { O\&M } \\
\text { Cost, } \\
\$ / Y r\end{array}$ \\
\hline $\begin{array}{r}166.1 \\
15.0\end{array}$ & $\begin{array}{l}6.3 \\
0.1\end{array}$ \\
\hline 16.2 & 0.0 \\
\hline 18.0 & 0.0 \\
\hline 31.1 & 1.1 \\
\hline 1.6 & 0.3 \\
\hline 8.9 & 0.2 \\
\hline 0.0 & 1.2 \\
\hline 83.6 & 3.4 \\
\hline 0.3 & 0.0 \\
\hline 0.0 & 0.0 \\
\hline 6.3 & 0.0 \\
\hline
\end{tabular}

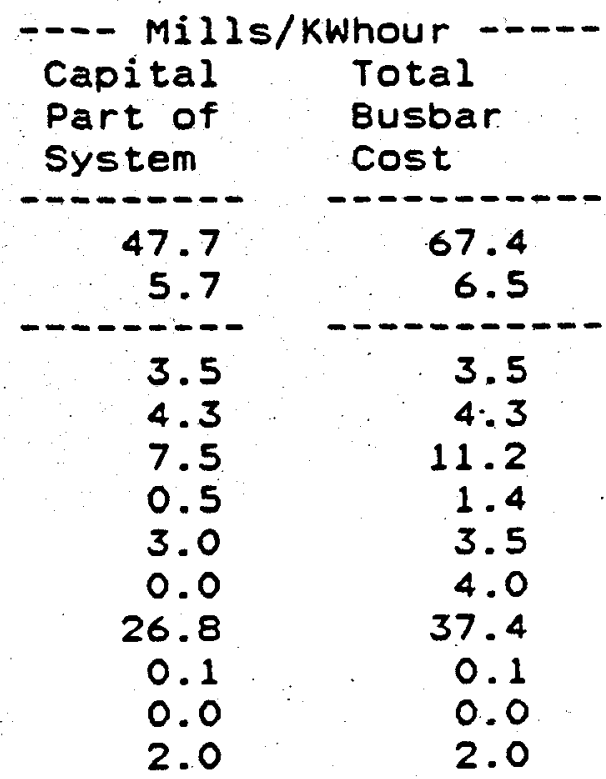


IrI-GEO: SENSITIVITY FACTORS IN EFFECT 08-01-1990 - 13:30:44

R\&D Achumt: BINARY Plant - Capital Cost : 0.76

Regional Weights $=$ Regional Capacity

(End of Page)

GEOTHERMAL COST OF POWER ESTIMATE Base Case Costs: Basin \& Range - Dixie Val

RUN: 08-01-1990-13:30:44

\section{[From IMGEO Model]}

ACCOUNT

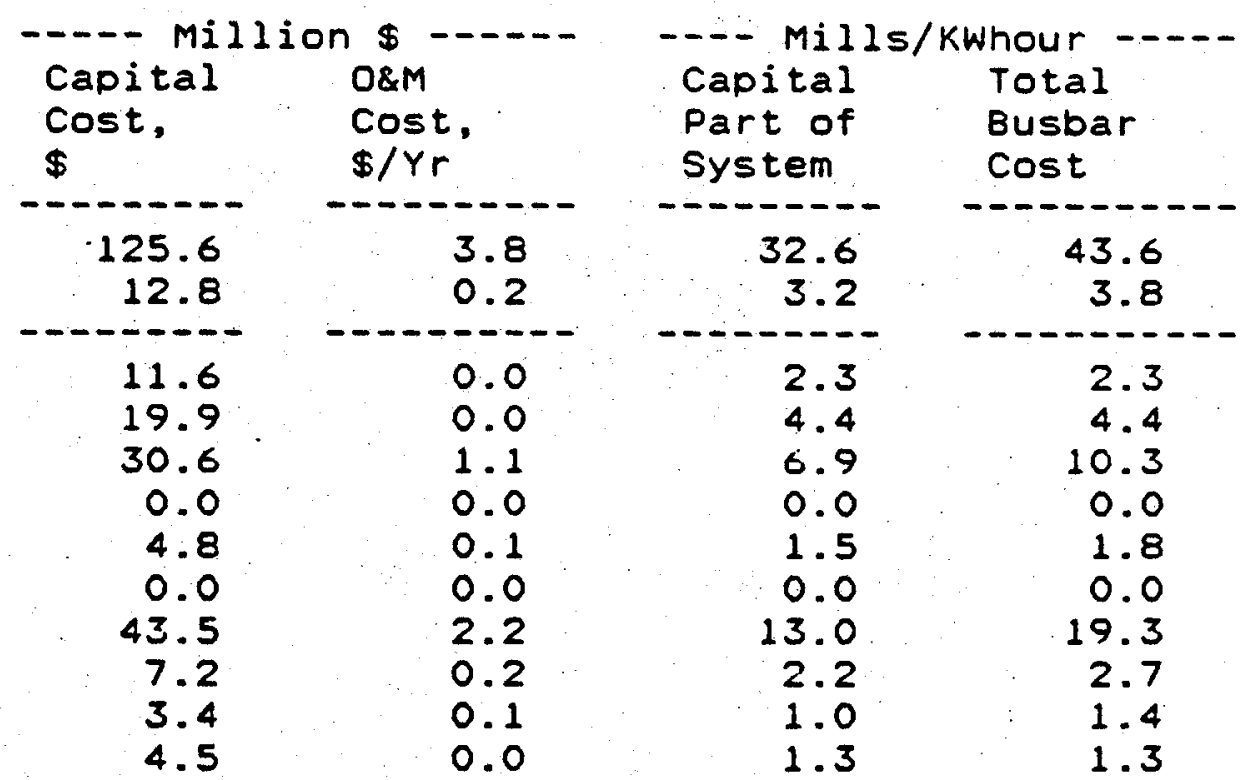

IM-GEO: SENSITIVITY FACTORS IN EFFECT 08-01-1990-13:30:44

R\&D Achumt: BINARY Plant - Capital cost : 0.76

Regional Weights = Regional Capacity

(End of Page)

GEOTHERMAL COST OF POWER ESTIMATE Base Case Costs: Basin \& Range - Raft R.

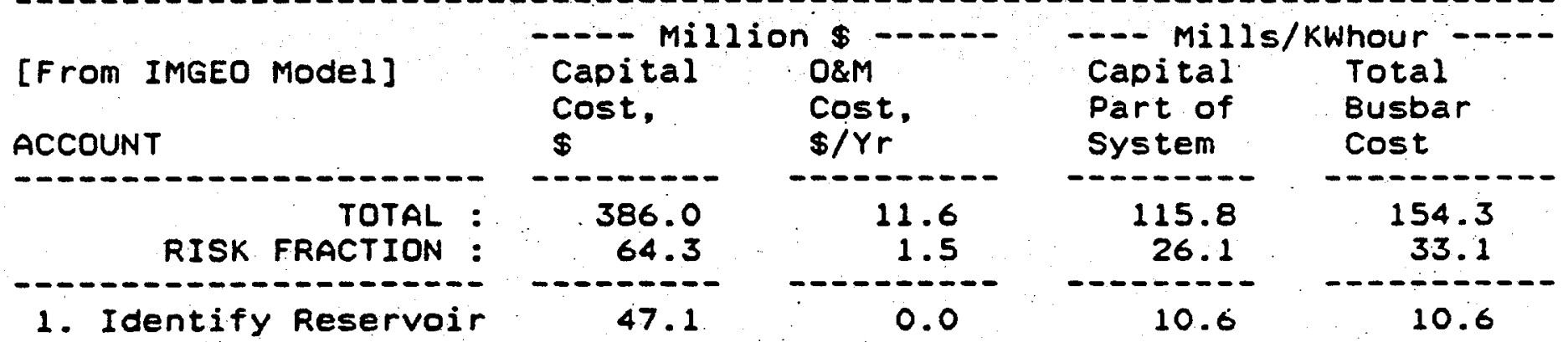


2. Confirm Reservoir

3. Prod./Inject. Wells

4. Downhole Pumps

5. Gathering Equip.

6. Make-Up Wells

7. Power Plant (Core)

8. Brine TDS Effects

9. Gas Handling

10. Reservoir Insurance

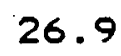

90.9

5.8

41.8

0.0

158.0

0.7

0.0

14.9
0.0

6.7

6.7

2.8

1.0

0.8

1.2

5.7

0.0

0.0

0.0
23.2

2.0

14.7

0.0

53.4

0.2

0.0

5.0
32.8

5.5

17.5

4.1

71.8

0.3

0.0

5.0

IM-GEO: SENSITIVITY FACTORS IN EFFECT 08-01-1990-13:30:44

R\&D Achumt: BINARY Plant - Capital cost : 0.76

Regional Weights = Regional Capacity

(End of Page)

GEOTHERMAL COST OF POWER ESTIMATE Base Case Costs: Cascades - Lassen

RUN: $08-01-1990-13: 30: 44$

[From IMGEO Model]

ACCOUNT

ACCOUNT

$$
\cdots
$$

RISK FRACTION :

1. Identify Reservoir

2. Confirm Reservoir

3. Prod./Inject. Wells

4. Downhole Pumps

5. Gathering Equip.

6. Make-Up Wells

7. Power Plant (Core)

8. Brine TDS Effects

9. Gas Handling

10. Reservoir Insurance
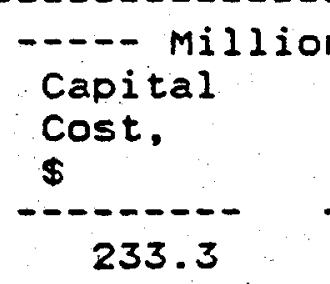

27.8

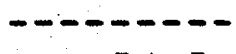

24.9

33.3

102.7

0.0

9.6

0.0

54.5

0.0

0.0

8.3

IM-GEO: SENSITIVITY FACTORS IN EFFECT 08-01-1990-13:30:44

R\&D Achumt: BINARY Plant - Capital cost : 0.76

Regional Weights = Regional Capacity

(End of Page) 


\section{[From IMGEO Model]}

ACCOUNT

ACCOUNT - - - - - - - - -

TOTAL :

RISK FRACTION :

1. Identify Reservoir

2. Confirm Reservoir

3. Prod./Inject. Wells

4. Downhole Pumps

5. Gathering Equip.

6. Make-Up Wells

7. Power Plant (Core)

8. Brine TDS Effects

9. Gas Handling

10. Reservoir Insurance

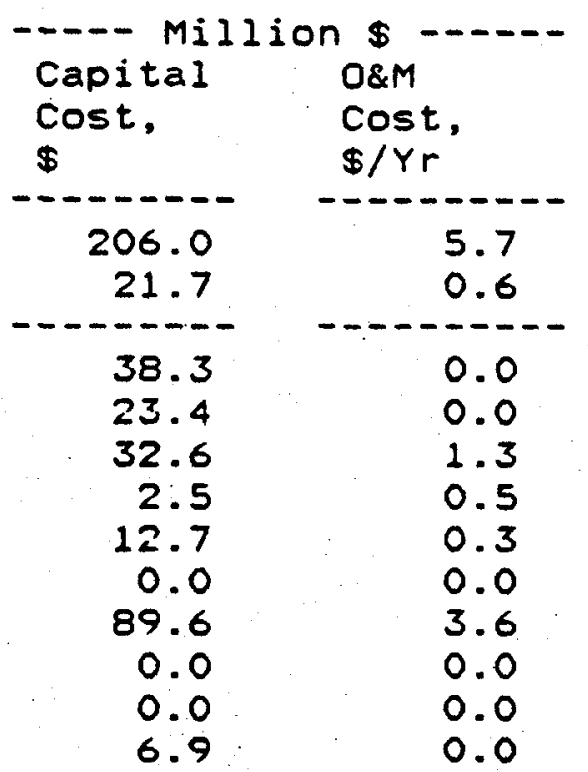

-.-- Mills/KWhour -..--

Capital

Part of

System

Total

Busbar

Cost

\begin{tabular}{cc}
54.9 & 71.7 \\
6.7 & 8.6 \\
\hline 7.8 & 7.8 \\
5.3 & 5.3 \\
7.5 & 11.6 \\
0.8 & 2.2 \\
4.0 & 4.8 \\
0.0 & 0.0 \\
27.4 & 38.1 \\
0.0 & 0.0 \\
0.0 & 0.0 \\
2.1 & 2.1
\end{tabular}

IM-GEO: SENSITIVITY FACTORS IN EFFECT 08-01-1990-13:30:44

R\&D Achvmt: BINARY Plant - Capital Cost : 0.76

Regional Weights = Regional Capacity

(End of Page)

GEOTHERMAL COST OF POWER ESTIMATE

Base Case costs: Young Volcanics - Coso

\begin{tabular}{|c|c|c|c|c|}
\hline $\begin{array}{l}\text { From IMGEO Model] } \\
\text { CCOUNT }\end{array}$ & $\begin{array}{l}\text { Capital } \\
\text { Cost. } \\
\$\end{array}$ & $\begin{array}{l}\text { O\&M } \\
\text { Cost. } \\
\$ / Y r\end{array}$ & $\begin{array}{l}\text { Capital } \\
\text { Part of } \\
\text { System }\end{array}$ & $\begin{array}{l}\text { Total } \\
\text { Busbar } \\
\text { Cost }\end{array}$ \\
\hline $\begin{array}{r}\text { TOTAL : } \\
\text { RISK FRACTION : }\end{array}$ & $\begin{array}{r}114.1 \\
7.0\end{array}$ & $\begin{array}{l}8.4 \\
0.3\end{array}$ & $\begin{array}{r}30.9 \\
1.8\end{array}$ & $\begin{array}{r}55.3 \\
2.8\end{array}$ \\
\hline $\begin{array}{l}\text { 1. Identify Reservoir } \\
\text { 2. Confirm Reservoir } \\
\text { 3. Prod./Inject. Wells } \\
\text { 4. Downhole Pumps } \\
\text { 5. Gathering Equip. } \\
\text { 6. Make-Up Wells } \\
\text { 7. Power Plant (Core) } \\
\text { 8. Brine TDS Effects } \\
\text { 9. Gas Handling } \\
\text { 0. Reservoir Insurance }\end{array}$ & $\begin{array}{r}6.6 \\
15.8 \\
19.5 \\
0.0 \\
4.8 \\
0.0 \\
42.7 \\
17.0 \\
3.3 \\
4.4\end{array}$ & $\begin{array}{l}0.0 \\
0.0 \\
2.8 \\
0.0 \\
0.2 \\
0.1 \\
2.1 \\
2.9 \\
0.2 \\
0.0\end{array}$ & $\begin{array}{r}1.3 \\
3.5 \\
4.4 \\
0.0 \\
1.5 \\
0.0 \\
12.8 \\
5.1 \\
1.0 \\
1.3\end{array}$ & $\begin{array}{r}1.3 \\
3.5 \\
12.8 \\
0.0 \\
2.0 \\
0.4 \\
18.9 \\
13.5 \\
1.6 \\
1.3\end{array}$ \\
\hline
\end{tabular}

IM-GEO: SENSITIVITY FACTORS IN EFFECT 08-01-1990 - 13:30:44

R\&D AChumt: BINARY Plant - Capital Cost : 0.76 
Regional Weights = Regional Capacity

(End of Page)

GEOTHERMAL COST OF POWER ESTIMATE

Base Case Costs: Young Vol. - Long Valley

RUN : $08-01-1990-13: 30: 44$

\begin{tabular}{|c|c|c|c|c|}
\hline $\begin{array}{l}\text { [From IMGEO Model] } \\
\text { ACCOUNT }\end{array}$ & $\begin{array}{l}\text { Capital } \\
\text { Cost } \\
\$\end{array}$ & $\begin{array}{l}\text { O\&M } \\
\text { Cost. } \\
\$ / Y r\end{array}$ & $\begin{array}{l}\text { Capital } \\
\text { Part of } \\
\text { System }\end{array}$ & $\begin{array}{l}\text { Total } \\
\text { Busbar } \\
\text { Cost }\end{array}$ \\
\hline $\begin{array}{r}\text { TOTAL : } \\
\text { RISK FRACTION : }\end{array}$ & $\begin{array}{r}138.4 \\
12.4\end{array}$ & $\begin{array}{l}5.1 \\
0.4\end{array}$ & $\begin{array}{r}40.0 \\
4.2\end{array}$ & $\begin{array}{c}55.5 \\
5.7\end{array}$ \\
\hline $\begin{array}{l}\text { 1. Identify Reservoir } \\
\text { 2. Confirm Reservoir } \\
\text { 3. Prod./Inject. Welis } \\
\text { 4. Downhole Pumps } \\
\text { 5. Gathering Equip. } \\
\text { 6. Make-Uo Wells } \\
\text { 7. Power Plant (Core) } \\
\text { 8. Brine TOS Effects } \\
\text { 9. Gas Handling } \\
\text { 10. Reservoir Insurance }\end{array}$ & $\begin{array}{r}8.3 \\
9.9 \\
20.2 \\
1.4 \\
11.1 \\
0.0 \\
81.8 \\
0.1 \\
0.0 \\
5.7\end{array}$ & $\begin{array}{l}0.0 \\
0.0 \\
1.1 \\
0.3 \\
0.2 \\
0.0 \\
3.4 \\
0.0 \\
0.0 \\
0.0\end{array}$ & $\begin{array}{r}1.7 \\
2.3 \\
4.8 \\
0.5 \\
3.6 \\
0.0 \\
25.5 \\
0.0 \\
0.0 \\
1.8\end{array}$ & $\begin{array}{r}1.7 \\
2.3 \\
8.3 \\
1.5 \\
4.3 \\
0.0 \\
35.6 \\
0.0 \\
0.0 \\
1.8\end{array}$ \\
\hline
\end{tabular}

IM-GEO: SENSITIVITY FACTORS IN EFFECT 08-01-1990- $13: 30: 44$

R\&D Achvmt: BINARY Plant - Capital Cost : 0.76

Regional Weights = Regional Capacity

(End of Page) 
IM-GEO: SENSITIVITY FACTORS IN EFFECT 08-01-1990 - 12:57:28

R\&D Achumt: BINARY Plant - Capital Cost : 0.76

Regional Weights = Regional Capacity

(End of Page)

GEOTHERMAL COST OF POWER ESTIMATE

Base Case Costs: Basin \& Range - Desert Pe

RUN: $08-01-1990-12: 57: 28$

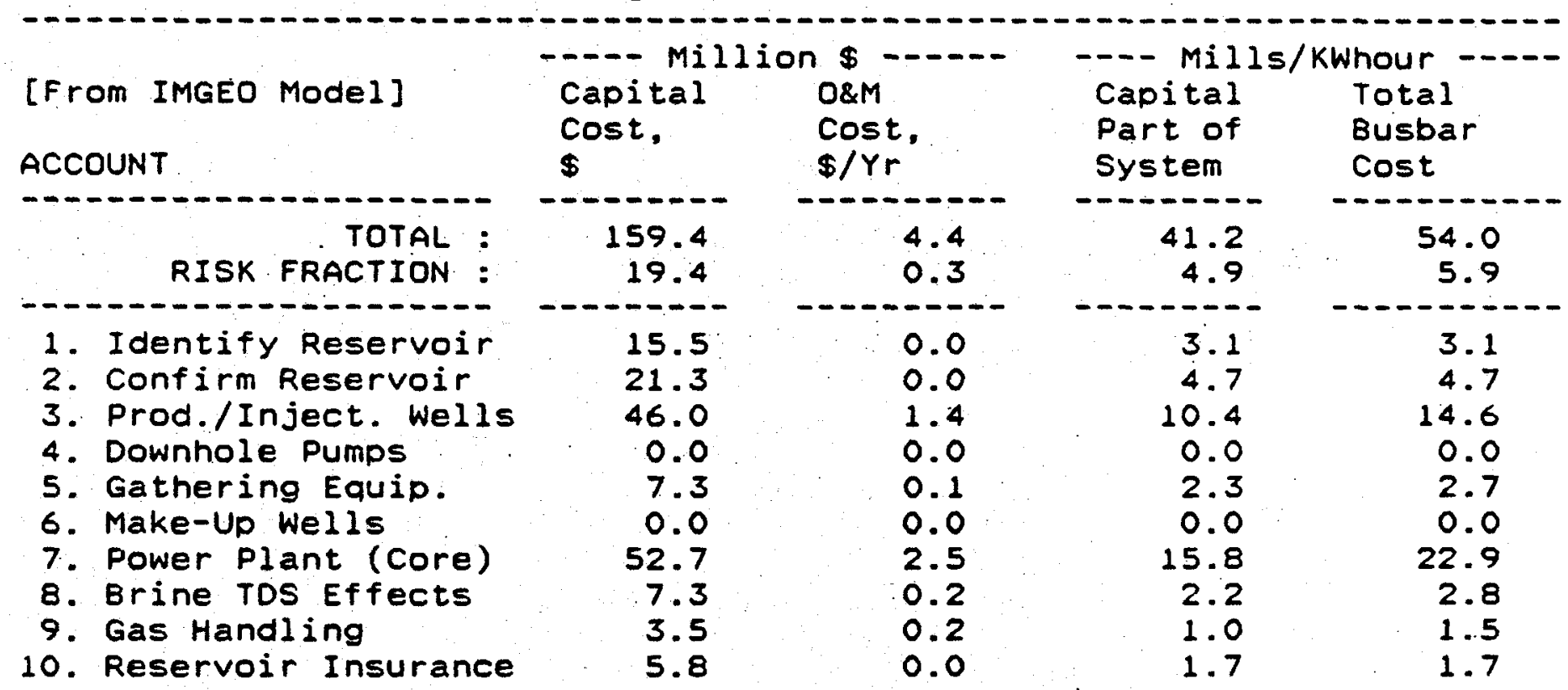

IM-GEO: SENSITIVITY FACTORS IN EFFECT 08-01-1990 - 12:57:28

R\&D Achumt: BINARY Plant - Capital Cost : 0.76

Regional Weights = Regional Capacity

(End of Page)

GEOTHERMAL COST OF POWER ESTIMATE RUN: 08-01-1990-12:57:28 Base Case Costs: Basin \& Range - Cove $\mathrm{Cr}$.

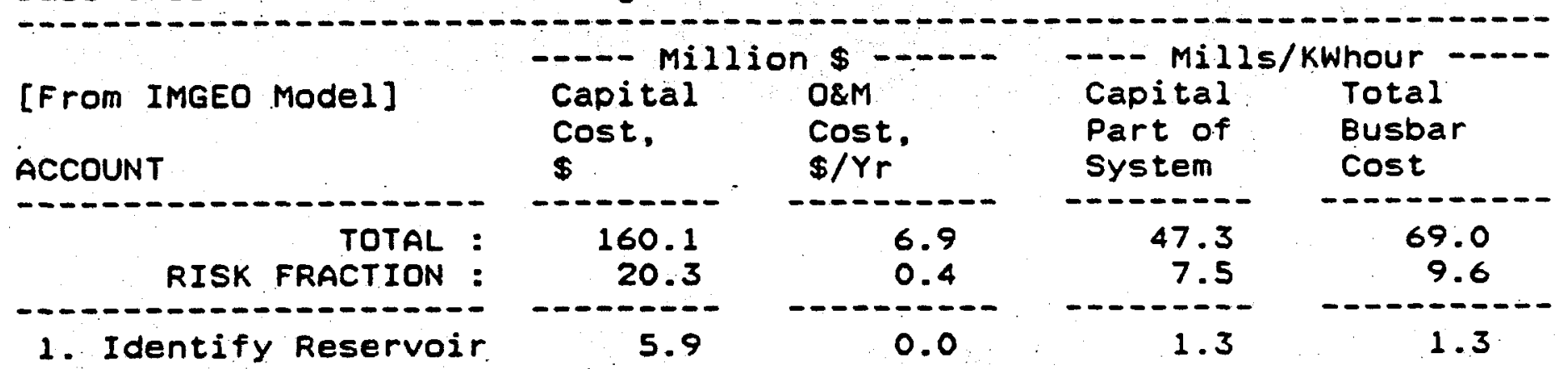


2. Confirm Reservoir

3. Prod./Inject. Wells

4. Downhole Pumps

5. Gathering Equip.

6. Make-Up Wells

7. Power Plant (Core)

8. Brine TDS Effects

9. Gas Handling

10. Reservoir Insurance
10.2

37.8

2.7

15.7

0.0

80.5

0.4

0.0

6.9
0.0

2.4

9.2

0.9

5.2

0.0

25.9

0.1

0.0

2.2

\section{IM-GEO: SENSITIVITY FACTORS IN EFFECT 08-01-1990 - 12:57:28}

R\&D Achumt: BINARY Plant - Capital cost : 0.76

Regional Weights = Regional Capacity

(End of Page)

GEOTHERMAL COST OF POWER ESTIMATE Base Case Costs: Cascades - Medicine L.

RUN : $08-01-1990-12: 57: 28$

\begin{tabular}{|c|c|c|c|c|}
\hline $\begin{array}{l}\text { [From IMGEO Model] } \\
\text { ACCOUNT }\end{array}$ & $\begin{array}{l}\text { Capital } \\
\text { Cost } \\
\$\end{array}$ & $\begin{array}{l}\text { O\&M } \\
\text { Cost } \\
\$ / Y r\end{array}$ & $\begin{array}{l}\text { Capital } \\
\text { Part of } \\
\text { System }\end{array}$ & $\begin{array}{l}\text { Total } \\
\text { Busbar } \\
\text { Cost }\end{array}$ \\
\hline $\begin{array}{r}\text { TOTAL : } \\
\text { RISK FRACTION : }\end{array}$ & $\begin{array}{r}138.3 \\
14.0\end{array}$ & $\begin{array}{r}3.0 \\
-0.2\end{array}$ & $\begin{array}{r}35.0 \\
3.6\end{array}$ & $\begin{array}{r}43.8 \\
2.9\end{array}$ \\
\hline $\begin{array}{l}\text { 1. Identify Reservoir } \\
\text { 2. Confirm Reservoir } \\
\text { 3. Prod./Inject. Wells } \\
\text { 4. Downhole Pumps } \\
\text { 5. Gathering Equip. } \\
\text { 6. Make-Up Wells } \\
\text { 7. Power Plant (Core) } \\
\text { 8. Brine TOS Effects } \\
\text { 9. Gas Handling } \\
\text { 10. Reservoir Insurance }\end{array}$ & $\begin{array}{r}10.2 \\
27.9 \\
48.8 \\
0.0 \\
4.5 \\
0.0 \\
42.2 \\
0.0 \\
0.0 \\
4.8\end{array}$ & $\begin{array}{l}0.0 \\
0.0 \\
0.6 \\
0.0 \\
0.1 \\
0.2 \\
2.1 \\
0.0 \\
0.0 \\
0.0\end{array}$ & $\begin{array}{r}2.0 \\
6.2 \\
11.2 \\
0.0 \\
1.4 \\
0.0 \\
12.8 \\
0.0 \\
0.0 \\
1.4\end{array}$ & $\begin{array}{r}2.0 \\
6.2 \\
13.0 \\
0.0 \\
1.7 \\
0.6 \\
18.9 \\
0.0 \\
0.0 \\
1.4\end{array}$ \\
\hline
\end{tabular}

IM-GEO: SENSITIVITY FACTORS IN EFFECT 08-01-1990 - 12:57:28

R\&D Achumt: BINARY Plant - Capital cost: 0.76

Regional Weights = Regional Capacity

(End of Page) 
Regional Weights $=$ Regional Capacity

(End of Page)

GEOTHERMAL COST OF POWER ESTIMATE

Base Case Costs: Young Volcanics - Randsbu

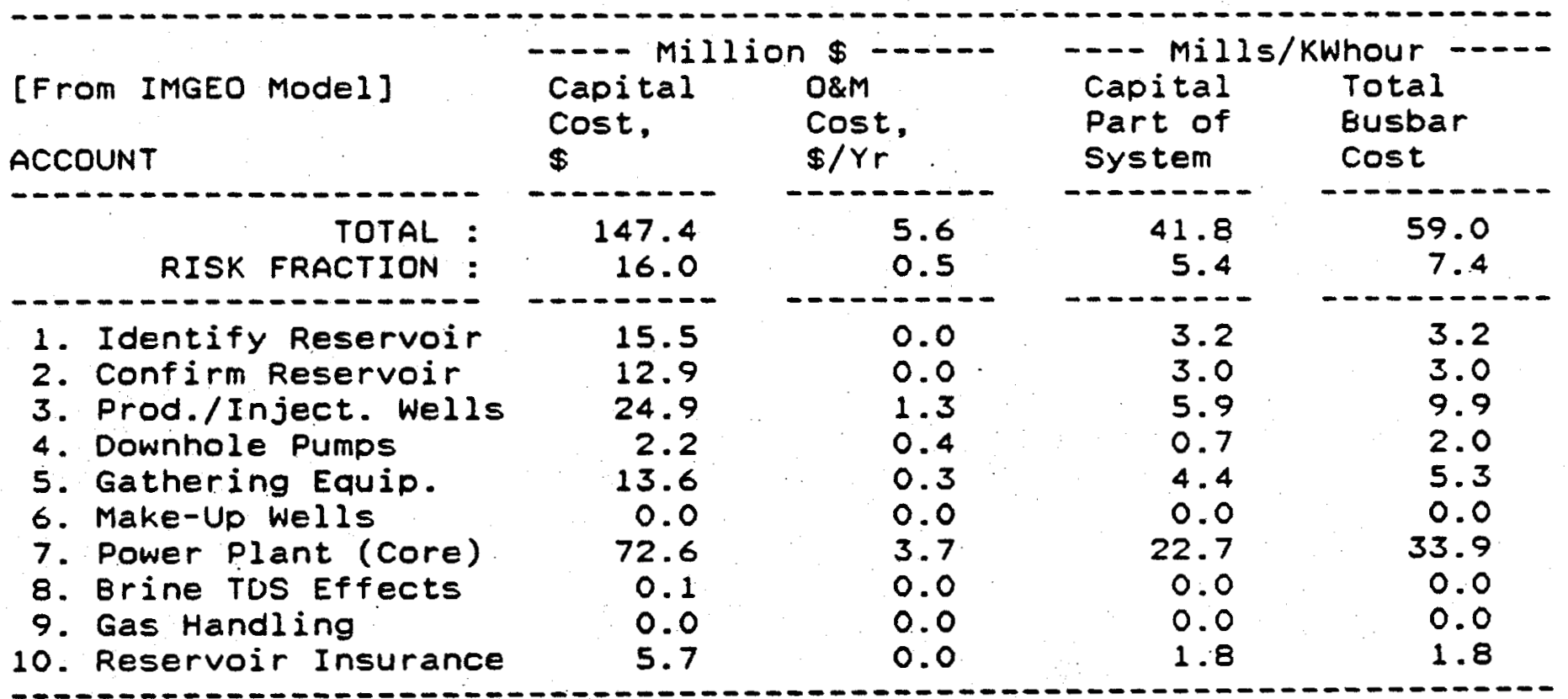

IM-GEO: SENSITIVITY FACTORS IN EFFECT 08-01-1990 - 12:57:28

R\&D Achumt: BINARY Plant - Capital Cost : 0.76

Regional weights = Regional Capacity

(End of Page) 
GEOTHERMAL COST OF POWER ESTIMATE Base Case costs: Imperial Valley - Brawley

RUN : 08-01-1990- $14: 56: 47$

\begin{tabular}{|c|c|c|c|c|}
\hline $\begin{array}{l}\text { [From IMGED Model] } \\
\text { ACCOUNT }\end{array}$ & $\begin{array}{l}\text { Capital } \\
\text { Cost. } \\
\$\end{array}$ & $\begin{array}{l}\text { O\&M } \\
\text { Cost } \\
\$ / Y r\end{array}$ & $\begin{array}{l}\text { Capital } \\
\text { Part of } \\
\text { System }\end{array}$ & $\begin{array}{l}\text { Total } \\
\text { Busbar } \\
\text { Cost }\end{array}$ \\
\hline $\begin{array}{r}\text { TOTAL : } \\
\text { RISK FRACTION : }\end{array}$ & $\begin{array}{r}129.3 \\
7.1\end{array}$ & $\begin{array}{l}8.3 \\
0.5\end{array}$ & $\begin{array}{r}34.4 \\
1.8\end{array}$ & $\begin{array}{r}58.5 \\
3.3\end{array}$ \\
\hline $\begin{array}{l}\text { 1. Identify Reservoir } \\
\text { 2. Confirm Reservoir } \\
\text { 3. Prod./Inject. Wells } \\
\text { 4. Downhole Pumps } \\
\text { 5. Gathering Equip. } \\
\text { 6. Make-Up Wells } \\
\text { 7. Power Plant (Core) } \\
\text { 8. Brine TDS Effects } \\
\text { 9. Gas Handling } \\
\text { 10. Reservoir Insurance }\end{array}$ & $\begin{array}{r}8.0 \\
18.7 \\
27.8 \\
0.0 \\
5.6 \\
0.0 \\
43.8 \\
16.7 \\
3.8 \\
4.9\end{array}$ & $\begin{array}{l}0.0 \\
0.0 \\
3.1 \\
0.0 \\
0.2 \\
0.0 \\
2.2 \\
2.5 \\
0.2 \\
0.0\end{array}$ & $\begin{array}{r}1.6 \\
4.1 \\
6.3 \\
0.0 \\
1.8 \\
0.0 \\
13.1 \\
5.0 \\
1.1 \\
1.5\end{array}$ & $\begin{array}{r}1.6 \\
4.1 \\
15.6 \\
0.0 \\
2.4 \\
0.0 \\
19.4 \\
12.2 \\
1.7 \\
1.5\end{array}$ \\
\hline
\end{tabular}

IM-GEO: SENSITIVITY FACTORS IN EFFECT 08-01-1990 - 14:56:47

R\&D AChumt: BINARY Plant - Capital Cost : 0.76

Regional Weights = Regional Capacity

(End of Page)

GEOTHERMAL COST OF POWER ESTIMATE Base Case Costs: B \& R - Roosevelt HS.

RUN: $08-01-1990-14: 56: 47$

[From IMGEO MOdel]

ACCOUNT

TOTAL : RISK FRACTION :

1. Identify Reservoir

2. Confirm Reservoir

3. Prod./Inject. Wells

4. Downhole Pumps

5. Gathering Equip.

6. Make-Up Wells

7. Power Plant (Core)

8. Brine TDS Effects

9. Gas Handling

10. Reservoir Insurance

\begin{tabular}{|c|c|c|c|}
\hline $\begin{array}{l}\text { Capital } \\
\text { Cost. } \\
\$\end{array}$ & $\begin{array}{l}\text { O\&M } \\
\text { Cost } \\
\$ / Y r\end{array}$ & $\begin{array}{l}\text { Capital } \\
\text { Part of } \\
\text { System }\end{array}$ & $\begin{array}{l}\text { Total } \\
\text { Busbar } \\
\text { Cost }\end{array}$ \\
\hline $\begin{array}{r}101.4 \\
4.7\end{array}$ & $\begin{array}{r}3.5 \\
-0.1\end{array}$ & $\begin{array}{r}26.7 \\
1.2\end{array}$ & $\begin{array}{r}36.9 \\
1.0\end{array}$ \\
\hline $\begin{array}{r}15.4 \\
21.1 \\
5.9 \\
0.0 \\
2.2 \\
0.0 \\
43.1 \\
7.2 \\
3.3 \\
3.1\end{array}$ & $\begin{array}{l}0.0 \\
0.0 \\
0.8 \\
0.0 \\
0.0 \\
0.2 \\
2.2 \\
0.2 \\
0.1 \\
0.0\end{array}$ & $\begin{array}{r}3.1 \\
4.6 \\
1.3 \\
0.0 \\
0.7 \\
0.0 \\
12.9 \\
2.2 \\
1.0 \\
0.9\end{array}$ & $\begin{array}{r}3.1 \\
4.6 \\
3.6 \\
0.0 \\
0.8 \\
0.5 \\
19.1 \\
2.7 \\
1.4 \\
0.9\end{array}$ \\
\hline
\end{tabular}


IM-GEO: SENSITIVITY FACTORS IN EFFECT 08-01-1990 - 14:56:47

R\&D Achumt: BINARY Plant - Capital Cost : 0.76

Regional Weights = Regional Capacity

(End of Page)

GEOTHERMAL COST OF POWER ESTIMATE

RUN : 08-01-1990-14:56:47

Base Case costs: $B$ \& $R$ - Cove Fort

[From IMGEO Model]

ACCOUNT

TOTAL:
RISK FRACTION :

1. Identify Reservoir

2. Confirm Reservoir

3. Prod./Inject. Wells

4. Downhole Pumps

5. Gathering Equip.

6. Make-Up Wells

7. Power Plant (Core)

8. Brine TDS Effects

9. Gas Handling

10. Reservoir Insurance

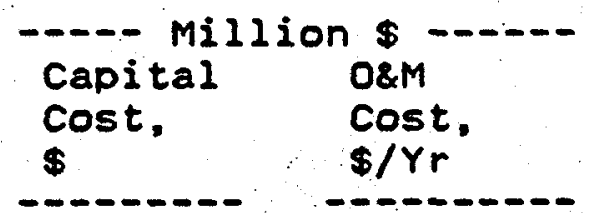

149.7

15.6

$--------$

10.3

11.9

29.3

2.1

12.5

0.0

77.2

0.4

0.0

6.1

\begin{tabular}{cc}
- Mills/KWhour \\
Capital & $\begin{array}{c}\text { Total } \\
\text { Busbar } \\
\text { Part of }\end{array}$ \\
System & Cost \\
\hline 43.8 & 65.0 \\
5.9 & 7.4 \\
\hline 2.2 & 2.2 \\
2.8 & 2.8 \\
7.1 & 11.4 \\
0.7 & 1.9 \\
4.1 & 4.9 \\
0.0 & 3.0 \\
24.7 & 36.6 \\
0.1 & 0.1 \\
0.0 & 0.0 \\
1.9 & 1.9
\end{tabular}

IM-GEO: SENSITIVITY FACTORS IN EFFECT 08-01-1990 - 14:56:47

R\&D Achumt: BINARY Plant - Capital Cost : 0.76

Regional Weights = Regional Capacity

(End of Page)

GEOTHERMAL COST OF POWER ESTIMATE

RUN: $08-01-1990-14: 56: 47$

Base Case costs: Cascades - Newberry

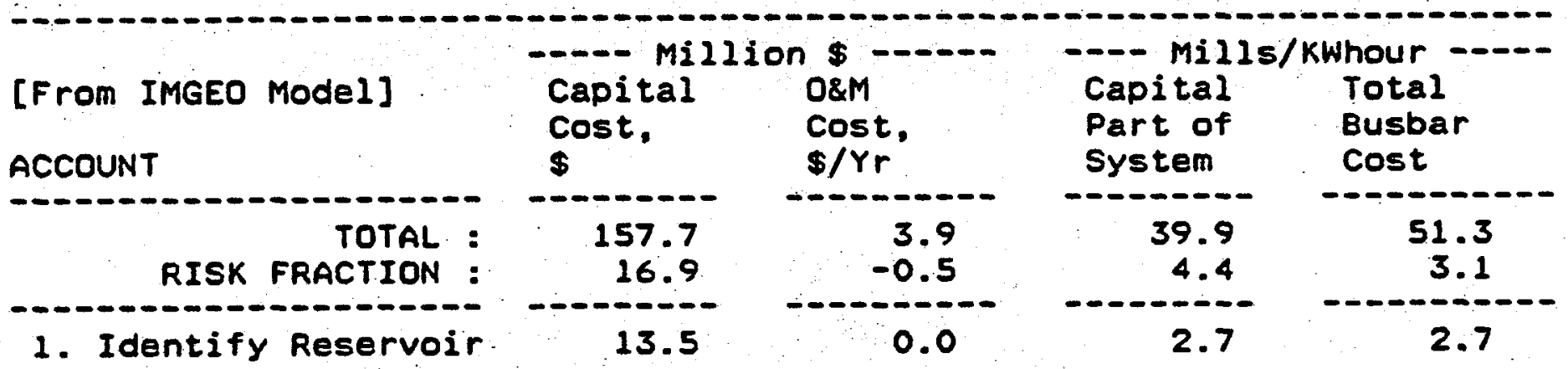


2. Confirm Reservoir

3. Prod./Inject. Wells

4. Downhole Pumps

6. Make-Up Wells

7. Power Plant (Core)

5.6

0.1

1.8

2.1

0.0

0.8

0.0

2.5

8. Brine TDS Effects

45.5

2.3

13.8

20.4

9. Gas Handling

0.0

0.0

0.0

0.0

0.0

0.0

0.0

10. Reservoir Insurance

5.5

0.0

1.7

1.7

IM-GEO: SENSITIVITY FACTORS IN EFFECT 08-01-1990 - 14:56:47

R\&D Achumt: BINARY Plant - Capital cost : 0.76

Regional Weights = Regional Capacity

(End of Page)

GEOTHERMAL COST OF POWER ESTIMATE Base Case Costs: Y Vol. - Long Valley HT

RUN : 08-01-1990-14:56:47

Base Case Costs: Y Vol

[From IMGEO Model]

ACCOUNT$$
--
$$

$--\cdots--$

TOTAL :
RISK FRACTION :

1. Identify Reservoir

2. Confirm Reservoir

3. Prod./Inject. Wells

4. Downhole Pumps

5. Gathering Equip.

6. Make-Up Wells

7. Power Plant (Core)

8. Brine TDS Effects

9. Gas Handling

10. Reservoir Insurance

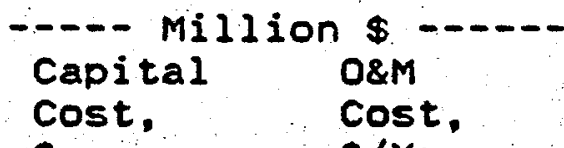

$\$$

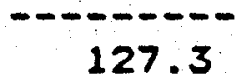

7.6

$--\cdots--\cdot-\cdot$

9.1

16.9

26.2

0.0

6.1

0.0

43.8

17.1

3.4

4.8
$\$ / Y r$
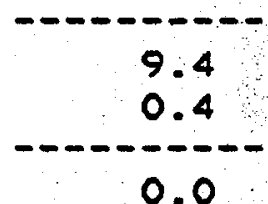

0.0

0.0

3.3

0.0

0.2

0.1

2.2

3.3

0.2

0.0
-... Mills/KWhour -...-

Capital

Part of

System

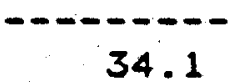

2.0

1.8

3.7

5.9

0.0

1.9

0.0

13.1

5.1

1.0

1.4
Total

Busbar

Cost

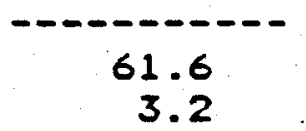

$-\cdots$

1.8

3.7

15.8

0.0

2.6

0.3

19.5

14.7

1.6

1.4

IM-GEO: SENSITIVITY FACTORS IN EFFECT 08-01-1990 - 14:56:47

R\&D Achumt: BINARY Plant - Capital cost : 0.76

Regional Weights = Regional Capacity

(End of Page) 
GEOTHERMAL COST OF POWER ESTIMATE

RUN : $08-01-1990-16: 03: 49$

Base Case Costs: B \& R - Beowowe

[From IMGEO Model]

ACCOUNT

RISK FRACTION :
1. Identify Reservoir
2. Confirm Reservoir
3. Prod./Inject. Wells
4. Downhole Pumps
5. Gathering Equip.
6. Make-UD Wells
7. Power Plant (Core)
8. Brine TOS Effects
9. Gas Handling

\begin{tabular}{cc}
0.0 \\
Capital & $\begin{array}{l}\text { O\&M } \\
\text { Cost, } \\
\text { Cost, } \\
\$\end{array}$ \\
\hline 175.2 & $4 / Y r$ \\
16.2 & 0.4 \\
\hline 27.8 & 0.0 \\
25.9 & 0.0 \\
43.9 & 1.4 \\
0.0 & 0.0 \\
7.1 & 0.1 \\
0.0 & 0.0 \\
53.9 & 2.5 \\
7.3 & 0.2 \\
3.5 & 0.2 \\
5.8 & 0.0 \\
\hline
\end{tabular}

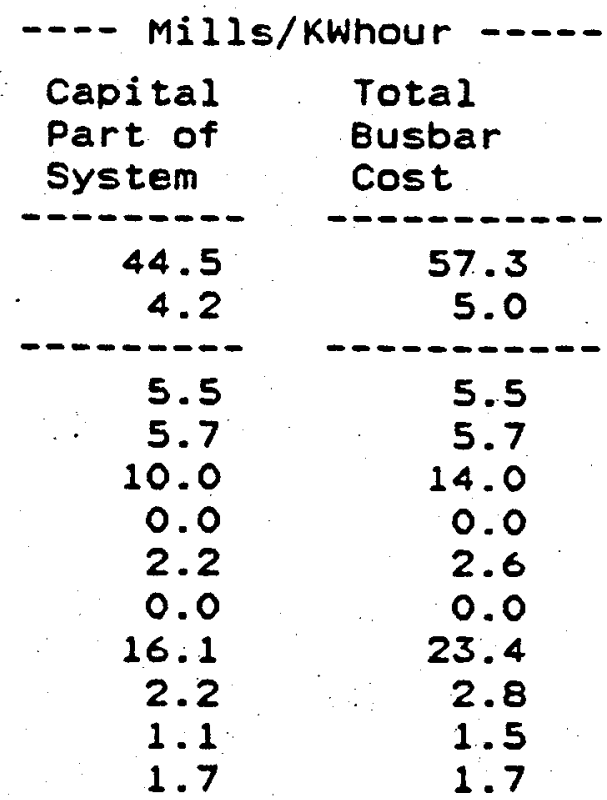

IM-GEO: SENSITIVITY FACTORS IN EFFECT 08-01-1990 - 16:03:49

R\&D Achumt: BINARY Plant - Capital Cost : 0.76

Regional Weights = Regional Capacity

(End of Page)

GEOTHERMAL COST OF POWER ESTIMATE RUN: 08-01-1990-16:03:49

Base Case costs: $B$ \& R - Surprise Valley

\begin{tabular}{|c|c|c|c|c|}
\hline $\begin{array}{l}\text { [From IMGEO Model] } \\
\text { ACCOUNT }\end{array}$ & $\begin{array}{l}\text { Capital } \\
\text { Cost. } \\
\$\end{array}$ & $\begin{array}{l}\text { O\&M } \\
\text { Cost. } \\
\$ / Y r\end{array}$ & $\begin{array}{l}\text { Capital } \\
\text { Part of } \\
\text { System }\end{array}$ & $\begin{array}{l}\text { Total } \\
\text { Busbar } \\
\text { Cost }\end{array}$ \\
\hline $\begin{array}{r}\text { TOTAL : } \\
\text { RISK FRACTION : }\end{array}$ & $\begin{array}{r}172.5 \\
22.4\end{array}$ & $\begin{array}{l}7.2 \\
0.4\end{array}$ & $\begin{array}{r}50.8 \\
8.3\end{array}$ & \\
\hline $\begin{array}{l}\text { 1. Identify Reservoir } \\
\text { 2. Confirm Reservoir } \\
\text { 3. Prod./Inject. Wells } \\
\text { 4. Downhole Pumps } \\
\text { 5. Gathering Equip. } \\
\text { 6. Make-Up Wells } \\
\text { 7. Power Plant (Core) } \\
\text { 8. Brine TDS Effects } \\
\text { 9. Gas Handling } \\
\text { 10. Reservoir Insurance }\end{array}$ & $\begin{array}{r}8.6 \\
11.3 \\
41.1 \\
2.9 \\
27.1 \\
0.0 \\
83.8 \\
0.4 \\
0.0 \\
7.3\end{array}$ & $\begin{array}{l}0.0 \\
0.0 \\
1.6 \\
0.5 \\
0.3 \\
0.6 \\
4.1 \\
0.0 \\
0.0 \\
0.0\end{array}$ & $\begin{array}{r}1.8 \\
2.7 \\
10.1 \\
1.0 \\
5.7 \\
0.0 \\
27.0 \\
0.1 \\
0.0 \\
2.3\end{array}$ & $\begin{array}{r}1.8 \\
2.8 \\
15.8 \\
2.8 \\
6.8 \\
1.8 \\
39.8 \\
0.2 \\
0.8 \\
2.8\end{array}$ \\
\hline
\end{tabular}


IM-GEO: SENSITIVITY FACTORS IN EFFECT 08-01-1990 - 16:03:49

R\&D Achumt: BINARY Plant - Capital Cost : 0.76

Regional Weights = Regional Capacity

(End of Page)

GEOTHERMAL COST OF POWER ESTIMATE

Base Case Costs: Cascades - 3 Creeks Butte

RUN: 08-01-1990-16:03:49

\begin{tabular}{|c|c|c|c|c|}
\hline $\begin{array}{l}\text { [From IMGEO Model] } \\
\text { ACCOUNT }\end{array}$ & $\begin{array}{l}\text { Capital } \\
\text { Cost, } \\
\$\end{array}$ & $\begin{array}{l}\text { O\&M } \\
\text { Cost } \\
\$ / Y r\end{array}$ & $\begin{array}{l}\text { Capital } \\
\text { Part of } \\
\text { System }\end{array}$ & $\begin{array}{l}\text { Total } \\
\text { Busbar } \\
\text { Cost }\end{array}$ \\
\hline RISK FRACTION : & $\begin{array}{r}140.3 \\
13.8\end{array}$ & $\begin{array}{r}3.7 \\
-0.4 \\
-.-1 .-1\end{array}$ & $\begin{array}{r}35.5 \\
3.6 \\
-\end{array}$ & $\begin{array}{r}46.2 \\
2.5\end{array}$ \\
\hline $\begin{array}{l}\text { 1. Identify Reservoir } \\
\text { 2. Confirm Reservoir } \\
\text { 3. Prod./Inject. Wells } \\
\text { 4. Downhole Pumps } \\
\text { 5. Gathering Equip. } \\
\text { 6. Make-Up Welis } \\
\text { 7. Power Plant (Core) } \\
\text { 8. Brine Tos Effects } \\
\text { 9. Gas Handling } \\
\text { 10. Reservoir Insurance }\end{array}$ & $\begin{array}{r}13.5 \\
29.1 \\
45.7 \\
0.0 \\
4.5 \\
0.0 \\
42.8 \\
0.0 \\
0.0 \\
4.7\end{array}$ & $\begin{array}{l}0.0 \\
0.0 \\
0.6 \\
0.0 \\
0.1 \\
0.8 \\
2.2 \\
0.0 \\
0.0 \\
0.0\end{array}$ & $\begin{array}{r}2.7 \\
6.5 \\
10.5 \\
0.0 \\
1.4 \\
0.0 \\
13.0 \\
0.0 \\
0.0 \\
1.4\end{array}$ & $\begin{array}{r}2.7 \\
6.5 \\
12.3 \\
0.0 \\
1.7 \\
2.4 \\
19.3 \\
0.0 \\
0.0 \\
1.4\end{array}$ \\
\hline
\end{tabular}

IM-GEO: SENSITIVITY FACTORS IN EFFECT 08-01-1990 - 16:03:49

R\&D Achumt: BINARY Plant - Capital Cost : 0.76

Regional Weights = Regional Capacity

(End of Page)

GEOTHERMAL COST OF POWER ESTIMATE

Base Case Costs: Cascades - Mt. Baker

RUN: $08-01-1990-16: 03: 49$

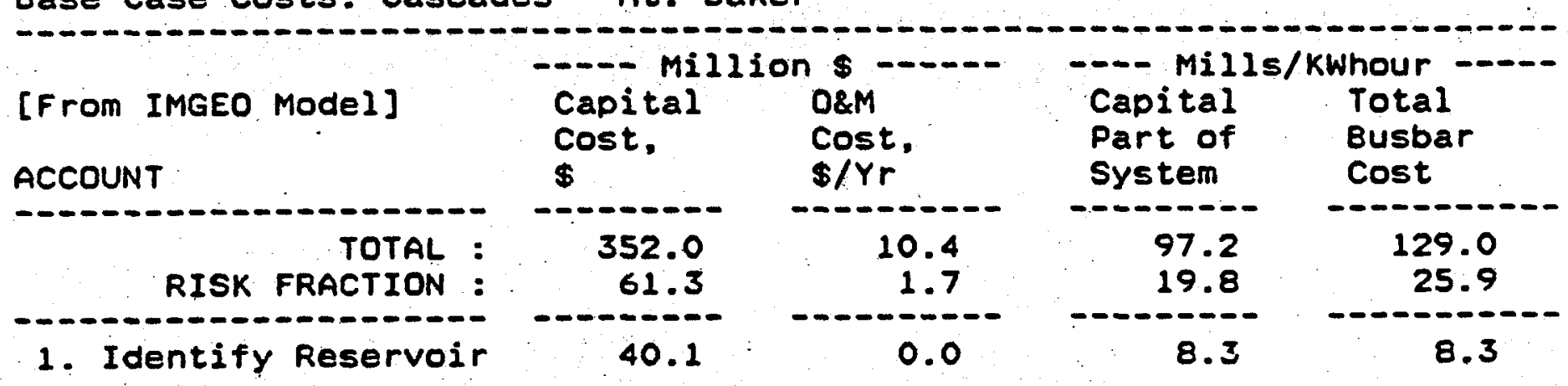


2. Confirm Reservoir

3. Prod./Inject. Wells

4. Downhole Pumps

5. Gathering Equip.

6. Make-Up Wells

7. Power Plant (Core)

8. Brine TDS Effects

9. Gas Handling

10. Reservoir Insurance
24.5

98.1

$6: 3$

43.5

0.0

125.7

0.1

0.0

13.7
0.0

2.7

1.1

0.9

0.0

5.7

0.0

0.0

0.0
5.6

23.3

2.0

14.2

0.0

39.4

0.0

0.0

4.3
5.6

31.6

5.6

16.9

0.0

56.6

0.0

0.0

4.3

IM-GEO: SENSITIVITY FACTORS IN EFFECT 08-01-1990-16:03:49

R\&D Achumt: BINARY Plant - Capital Cost : 0.76

Regional Weights = Regional Capacity

(End of Page)

GEOTHERMAL COST OF POWER ESTIMATE

RUN : 08-01-1990-16:03:49

Base Case Costs: Y Vol. - Island Park

\begin{tabular}{|c|c|c|c|c|}
\hline $\begin{array}{l}\text { [From IMGEO Model] } \\
\text { ACCOUNT }\end{array}$ & $\begin{array}{l}\text { Capital } \\
\text { Cost, } \\
\$\end{array}$ & $\begin{array}{l}\text { O\&M } \\
\text { Cost } \\
\$ / Y r\end{array}$ & $\begin{array}{l}\text { Capital } \\
\text { Part of } \\
\text { System }\end{array}$ & $\begin{array}{l}\text { Total } \\
\text { Busbar } \\
\text { Cost }\end{array}$ \\
\hline $\begin{array}{r}\text { TOTAL : } \\
\text { RISK FRACTION : }\end{array}$ & $\begin{array}{r}107.8 \\
7.5\end{array}$ & $\begin{array}{l}5.7 \\
0.3\end{array}$ & $\begin{array}{r}29.3 \\
2.1\end{array}$ & 46. \\
\hline $\begin{array}{l}\text { 1. Identify Reservoir } \\
\text { 2. Confirm Reservoir } \\
\text { 3. Prod./Inject. Wells } \\
\text { 4. Downhole Pumps } \\
\text { 5. Gathering Equip. } \\
\text { 6. Make-Up Wells } \\
\text { 7. Power Plant (Core) } \\
\text { 8. Brine TDS Effects } \\
\text { 9. Gas Handling } \\
\text { 10. Reservoir Insurance }\end{array}$ & $\begin{array}{l}6.6 \\
14.8 \\
18.5 \\
0.0 \\
4.5 \\
0.0 \\
48.6 \\
7.2 \\
3.5 \\
4.1\end{array}$ & $\begin{array}{l}0.0 \\
0.0 \\
2.8 \\
0.0 \\
0.1 \\
0.1 \\
2.4 \\
0.2 \\
0.2 \\
0.0\end{array}$ & $\begin{array}{r}1.3 \\
3.3 \\
4.2 \\
0.0 \\
1.4 \\
0.0 \\
14.6 \\
2.2 \\
1.0 \\
1.2\end{array}$ & $\begin{array}{r}1 . \\
3 . \\
12 . \\
0 . \\
1 . \\
0 . \\
21 . \\
2 . \\
1 .\end{array}$ \\
\hline
\end{tabular}

IM-GEO: SENSITIVITY FACTORS IN EFFECT 08-01-1990-16:03:49.

R\&D Achumt: BINARY Plant - Capital cost : 0.76

Regional Weights = Regional Capacity

(End of Page) 
GEOTHERMAL COST OF POWER ESTIMATE Base Case costs: Imperial Valley - Glamis

RUN: $08-02-1990-08: 46: 39$

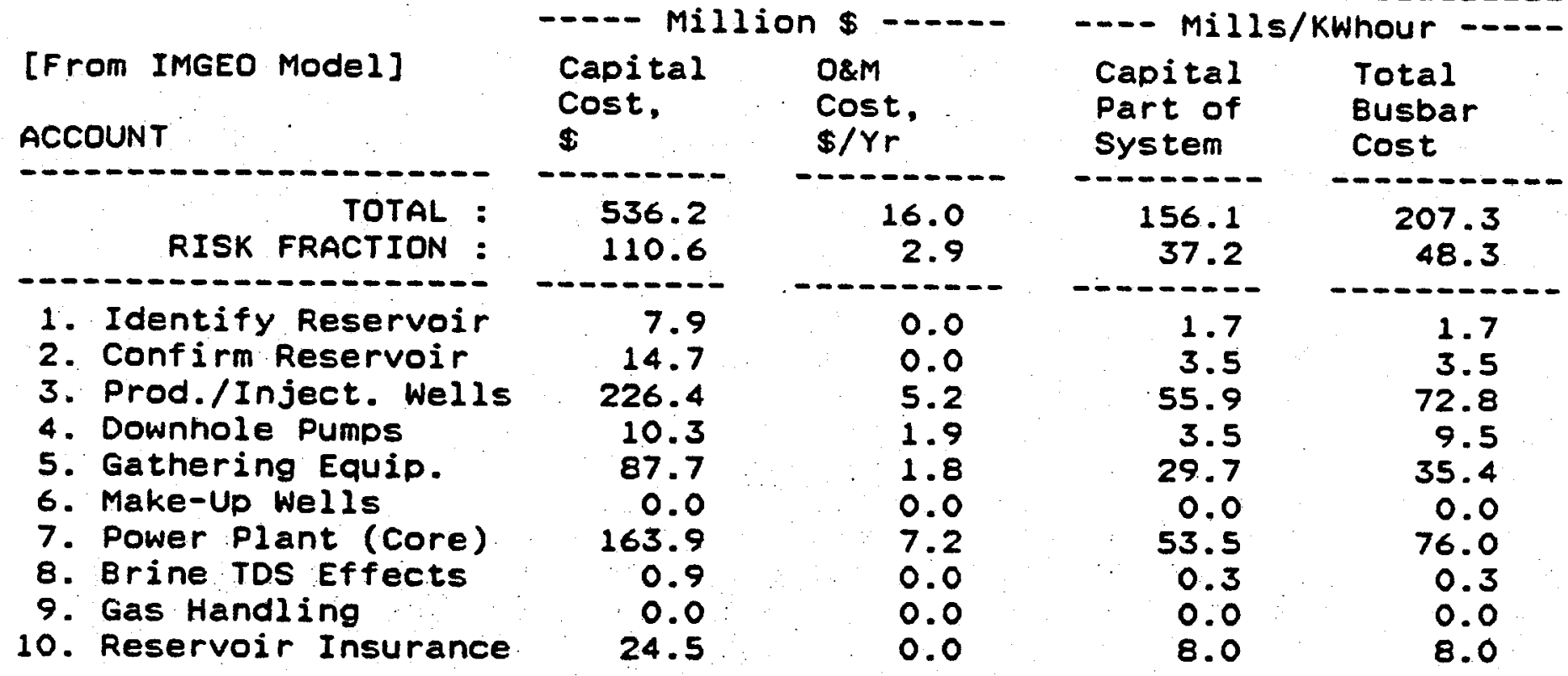

IM-GEO: SENSITIVITY FACTORS IN EFFECT 08-02-1990 - 08:46:39

R\&D Achvmt: BINARY Plant - Capital cost : 0.76

Regional Weights = Regional Capacity

(End of Page)

GEOTHERMAL COST OF POWER ESTIMATE

RUN: $08-02-1990-08: 46: 39$

Base Case Costs: B \& R - Hot Springs Ranch

[From IMGEO Model]

ACCOUNT

ACCOUNT

TOTAL:

RISK FRACTION :

1. Identify Reservoir

2. Confirm Reservoir

3. Prod./Inject. Wells

4. Downhole Pumps

5. Gathering Equip.

6. Make-Up Wells

7. Power Plant (Core)

8. Brine TDS Effects

9. Gas Handling

10. Reservoir Insurance

\section{Million \$}

\begin{tabular}{|c|c|}
\hline $\begin{array}{l}\text { Capital } \\
\text { Cost. } \\
\$\end{array}$ & $\begin{array}{l}\text { O\&M } \\
\text { Cost, } \\
\$ / Y r\end{array}$ \\
\hline $\begin{array}{r}274.3 \\
34.5\end{array}$ & $\begin{array}{l}8.2 \\
0.7\end{array}$ \\
\hline $\begin{array}{r}10.4 \\
18.9 \\
100.5 \\
3.7 \\
24.7 \\
0.0 \\
104.0 \\
0.6 \\
0.0 \\
11.7\end{array}$ & $\begin{array}{l}0.0 \\
0.0 \\
2.2 \\
0.7 \\
0.5 \\
0.0 \\
4.9 \\
0.0 \\
0.0 \\
0.0\end{array}$ \\
\hline
\end{tabular}

Mills/KWhour .....

Capital

Part of

System

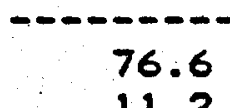

11.2

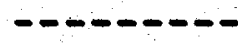

2.2

4.4

24.0

1.2

8.1

0.0

32.8

0.2

0.0

3.7
Total

Busbar

Cost

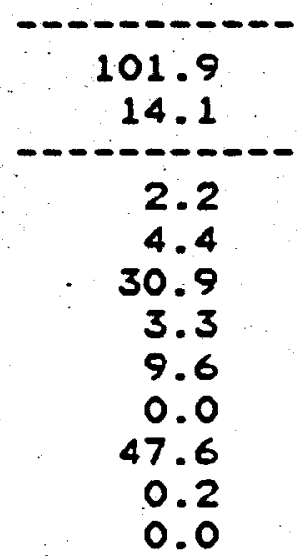

. 
•

IM-GEO: SENSITIVITY FACTORS IN EFFECT" 08-02-1990 - 08:46:39

R\&D Achumt: BINARY Plant - Capital Cost : 0.76

Regional Weights = Regional Capacity

(End of Page)

GEOTHERMAL COST OF POWER ESTIMATE RUN: 08-02-1990 - 08:46:39

Base Case Costs: Basin \& Range - Wendell

[From IMGEO MOdel]

ACCOUNT

RISK FRACT

TOTAL :

1. Identify Reservoir

2. Confirm Reservoir

3. Prod./Inject. Wells

4. Downhole Pumps

5. Gathering Equip.

6. Make-Up Wells

7. Power Plant (Core)

8. Brine TDS Effects

9. Gas Handling

10. Reservoir Insurance

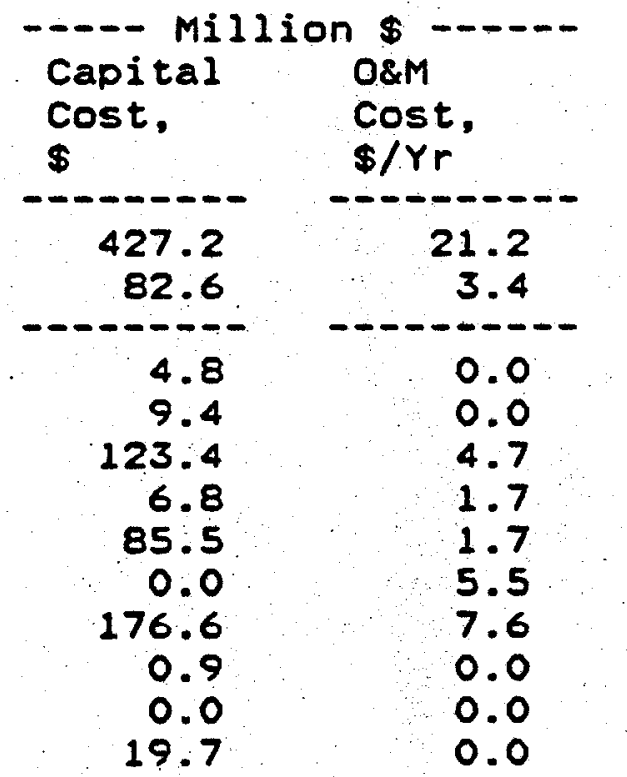

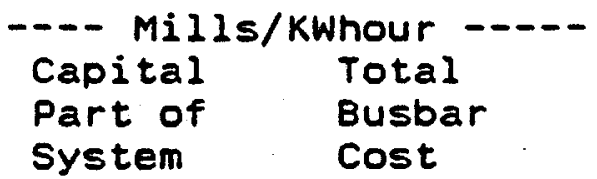

-

149.5

40.2

$-\cdots-\cdots$

1.2

2.6

35.2

2.7

33.4

0.0

66.6

0.4

0.0

7.4

Cost

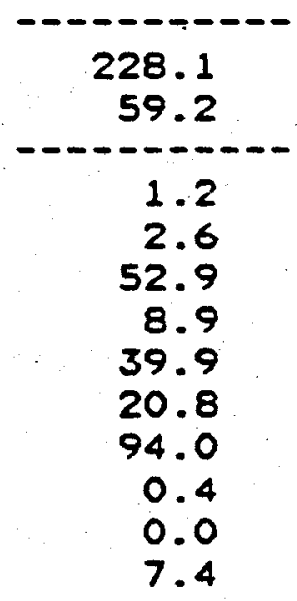

IM-GEO: SENSITIVITY FACTORS IN EFFECT 08-02-1990 - 08:46:39

RED AChumt: BINARY Plant - Capital cost : 0.76

Regional Weights = Regional Capacity

(End of Page)

GEOTHERMAL COST OF POWER ESTIMATE

Base Case Costs: Cascades - Keliy HS

[From IMGEO Model]

ACCOUNT

TOTAL:

RISK FRACTION :

1. Identify Reservoir

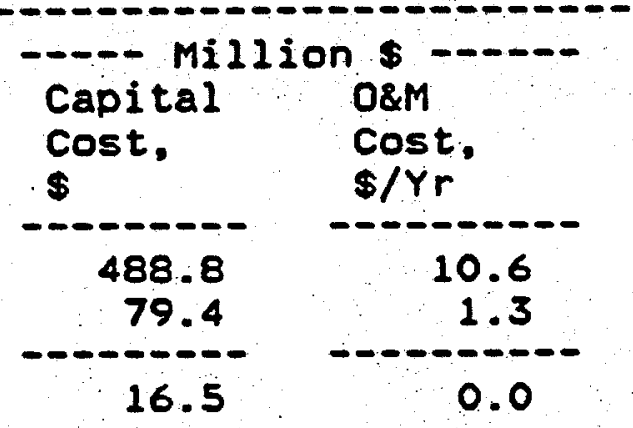

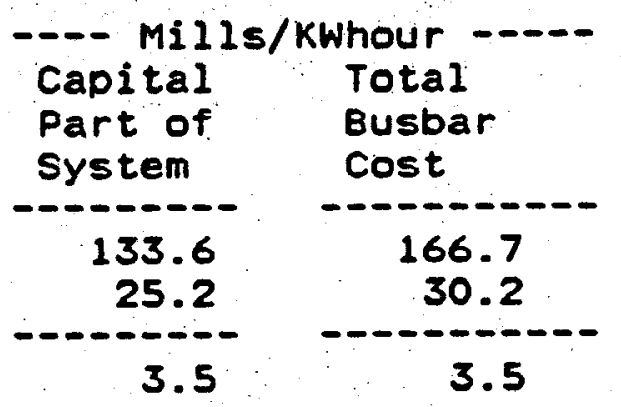


2. Confirm Reservoir

3. Prod./Inject. Wells

4. Downhole Pumps

5. Gathering Equip.

6. Make-Up Wells

7. Power Plant (Core)

8. Brine TDS Effects

9. Gas Mandling

10. Reservoir Insurance

$\begin{array}{rr}29.4 & 0.0 \\ 249.2 & 3.0 \\ 5.6 & 1.0 \\ 40.8 & 0.8 \\ 0.0 & 0.0 \\ 126.0 & 5.7 \\ 0.1 & 0.0 \\ 0.0 & 0.0 \\ 21.1 & 0.0\end{array}$

6.9

6.9

60.5

70.2

5.1

16.2

0.0

58.0

0.1

0.0

IM-GEO: SENSITIVITY FACTORS IN EFFECT 08-02-1990 - 08:46:39

R\&D AChumt: BINARY Plant - Capital cost : 0.76

Regional Weights = Regional Capacity

(End of Page)

GEOTHERMAL COST OF POWER ESTIMATE New Techology Costs: B \& R - Vale

RUN: $08-02-1990-08: 46: 39$

\begin{tabular}{|c|c|c|c|c|}
\hline $\begin{array}{l}\text { [From IMGEO Model] } \\
\text { ACCOUNT }\end{array}$ & $\begin{array}{l}\text { Capital } \\
\text { cost. } \\
\$\end{array}$ & $\begin{array}{l}\text { O\&M } \\
\text { Cost. } \\
\$ / Y r\end{array}$ & $\begin{array}{l}\text { Capital } \\
\text { Part of } \\
\text { System }\end{array}$ & $\begin{array}{l}\text { Total } \\
\text { Busbar } \\
\text { Cost }\end{array}$ \\
\hline $\begin{array}{r}\text { TOTAL : } \\
\text { RISK FRACTION : }\end{array}$ & $\begin{array}{r}215.7 \\
37.6\end{array}$ & $\begin{array}{l}8.5 \\
1.2\end{array}$ & $\begin{array}{r}62.8 \\
12.4\end{array}$ & 88. \\
\hline $\begin{array}{l}\text { 1. Identify Reservoir } \\
\text { 2. Confirm Reservoir } \\
\text { 3. Prod./Inject. Wells } \\
\text { 4. Downhole Pumps } \\
\text { 5. Gathering Equip. } \\
\text { 6. Make-Up Welis } \\
\text { 7. Power Plant (Core) } \\
\text { 8. Brine TDS Effects } \\
\text { 9. Gas Handling } \\
\text { 0. Reservoir Insurance }\end{array}$ & $\begin{array}{r}5.3 \\
10.1 \\
58.2 \\
4.3 \\
27.7 \\
0.0 \\
100.5 \\
0.1 \\
0.0 \\
9.5\end{array}$ & $\begin{array}{l}0.0 \\
0.0 \\
2.4 \\
0.8 \\
0.6 \\
0.0 \\
4.8 \\
0.0 \\
0.0 \\
0.0\end{array}$ & $\begin{array}{r}1.1 \\
2.4 \\
13.9 \\
1.4 \\
9.1 \\
0.0 \\
31.8 \\
0.0 \\
0.0 \\
3.0\end{array}$ & $\begin{array}{r}1 . \\
2 . \\
21.5 \\
3 . \\
10.8 \\
0.1 \\
46.5 \\
0.1 \\
0.1 \\
3 .\end{array}$ \\
\hline
\end{tabular}

IM-GEO: SENSITIVITY FACTORS IN EFFECT, 08-02-1990 - 08:46:39

R\&D AChUmt: BINARY Plant - Capital cost : 0.76

Regional Weights = Regional Capacity

(End of Page) 


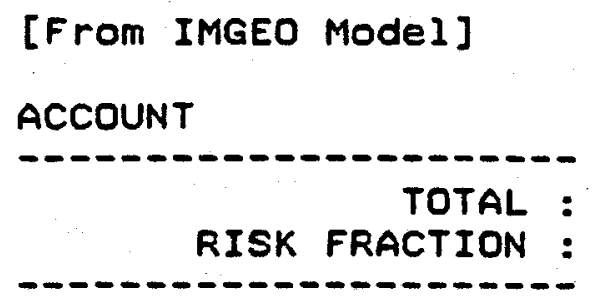

1. Identify Reservoir

2. Confirm Reservoir

3. Prod./Inject. Wells

4. Downhole Pumps

5. Gathering Equip.

6. Make-Up Wells

7. Power Plant (Core)

8. Brine TDS Effects

9. Gas Handling

10. Reservoir Insurance

\begin{tabular}{|c|c|c|c|}
\hline $\begin{array}{l}\text { Capital } \\
\text { Cost. } \\
\$\end{array}$ & $\begin{array}{l}\text { O\&M } \\
\text { Cost, } \\
\$ / Y r\end{array}$ & $\begin{array}{l}\text { Capital } \\
\text { Part of } \\
\text { System }\end{array}$ & $\begin{array}{l}\text { Total } \\
\text { Busbar } \\
\text { Cost }\end{array}$ \\
\hline $\begin{array}{l}629.1 \\
179.6\end{array}$ & $\begin{array}{r}22.2 \\
5.6\end{array}$ & $\begin{array}{r}192.5 \\
61.5\end{array}$ & $\begin{array}{r}265.0 \\
82.6\end{array}$ \\
\hline $\begin{array}{r}4.3 \\
8.6 \\
213.7 \\
15.4 \\
150.0 \\
0.0 \\
207.5 \\
0.2 \\
0.0 \\
29.3\end{array}$ & $\begin{array}{l}0.0 \\
0.0 \\
7.5 \\
2.8 \\
3.0 \\
0.0 \\
8.9 \\
0.0 \\
0.0 \\
0.0\end{array}$ & $\begin{array}{r}1.0 \\
2.1 \\
53.7 \\
5.3 \\
51.7 \\
0.0 \\
68.9 \\
0.1 \\
0.0 \\
9.7\end{array}$ & $\begin{array}{r}1.0 \\
2.1 \\
78.7 \\
14.6 \\
61.6 \\
0.0 \\
97.3 \\
0.1 \\
0.0 \\
9.7\end{array}$ \\
\hline
\end{tabular}

IM-GEO: SENSITIVITY FACTORS IN EFFECT 08-02-1990 - 08:46:39

R\&D Achumt: BINARY Plant - Capital cost : 0.76

Regional Weights = Regional Capacity

(End of Page) 
A REPORT FROM THE IM-GEO PROGRAM

GEOTHERMAL COST OF POWER ESTIMATE BASE CASE COSTS:

SITE = Deep fractures - Paradise

\begin{tabular}{|c|c|c|c|c|c|c|}
\hline From IM-GEO 3.05$]$ & $\begin{array}{l}\text { CAP. } \\
\text { SM }\end{array}$ & $\begin{array}{l}\text { SEM } \\
\text { SM/YR }\end{array}$ & $\begin{array}{l}\text { CAP. } \\
\text { PART }\end{array}$ & $\begin{array}{l}\text { Cents } \\
\text { O\&M } \\
\text { PART }\end{array}$ & $\begin{array}{l}\text { KWhour } \\
\text { TOTAL } \\
\text { COST }\end{array}$ & TOTAL \\
\hline $\begin{array}{r}\text { TOTAL : } \\
\text { RISK FRACTION : }\end{array}$ & $\begin{array}{r}414.9 \\
39.7\end{array}$ & $\begin{array}{r}13.3 \\
1.4\end{array}$ & $\begin{array}{r}11.46 \\
1.34\end{array}$ & $\begin{array}{l}4.13 \\
0.52\end{array}$ & $\begin{array}{r}15.60 \\
1.86\end{array}$ & 0.0 \\
\hline $\begin{array}{l}\text { 1. Identify Reservoir } \\
\text { 2. Confirm Reservoir } \\
\text { 3. Prod./Inject. Wells } \\
\text { 4. Downhole Pumps } \\
\text { 5. Gathering Equip. } \\
\text { 6. Make-Up Welis } \\
\text { 7. Power Plant (Core) } \\
\text { 8. Brine TDS Effects } \\
\text { 9. Gas Handling } \\
\text { 0. Reservoir Insurance }\end{array}$ & $\begin{array}{r}36.4 \\
27.9 \\
135.2 \\
5.0 \\
34.9 \\
0.0 \\
158.2 \\
0.7 \\
0.0 \\
16.7\end{array}$ & $\begin{array}{l}0.0 \\
0.0 \\
2.6 \\
0.9 \\
0.7 \\
5.0 \\
4.1 \\
0.0 \\
0.0 \\
0.0\end{array}$ & $\begin{array}{l}0.76 \\
0.65 \\
3.22 \\
0.16 \\
1.14 \\
0.00 \\
4.98 \\
0.02 \\
0.00 \\
0.53\end{array}$ & $\begin{array}{l}0.00 \\
0.00 \\
0.81 \\
0.29 \\
0.22 \\
1.57 \\
1.25 \\
0.00 \\
0.00 \\
0.00\end{array}$ & $\begin{array}{l}0.76 \\
0.65 \\
4.03 \\
0.45 \\
1.36 \\
1.57 \\
6.23 \\
0.03 \\
0.00 \\
0.53\end{array}$ & $\begin{array}{l}0.0 \\
0.0 \\
0.0 \\
0.0 \\
0.0 \\
0.0 \\
0.0 \\
0.0 \\
0.0 \\
0.0\end{array}$ \\
\hline
\end{tabular}

.PA (End of Page)

A REPORT FROM THE IM-GEO PROGRAM

GEOTHERMAL COST OF POWER ESTIMATE RUN O8-08-1990 - 11:45:11 BASE CASE COSTS: SITE = Deep fractures - Routt HS

\begin{tabular}{|c|c|c|c|c|c|c|}
\hline $\begin{array}{l}\text { [From IM-GEO } 3.05] \\
\text { ACCOUNT }\end{array}$ & SAP & $\begin{array}{l}S \& M \\
S M / Y R\end{array}$ & PART & $\begin{array}{l}\text { Cents } \\
\text { O\&M } \\
\text { PART }\end{array}$ & $\begin{array}{l}\text { KWhO } \\
\text { TOTAL } \\
\text { COST }\end{array}$ & $\begin{array}{l}\text { TOTAL } \\
\% \text { CHG }\end{array}$ \\
\hline $\begin{array}{r}\text { TOTAL : } \\
\text { RISK FRACTION }\end{array}$ & $\begin{array}{r}460.5 \\
47.1\end{array}$ & $\begin{array}{r}15.5 \\
1.7\end{array}$ & $\begin{array}{r}13.14 \\
1.70\end{array}$ & $\begin{array}{l}4.87 \\
0.67\end{array}$ & $\begin{array}{r}18.01 \\
2.37\end{array}$ & \\
\hline $\begin{array}{l}\text { 1. Identify Reservoir } \\
\text { 2. Confirm Reservoir } \\
\text { 3. Prod./Inject. Weils } \\
\text { 4. Downhole Pumps } \\
\text { 5. Gathering Equip. } \\
\text { 6. Make-Up Wells } \\
\text { 7. Power Plant (Core) } \\
\text { 8. Brine TDS Effects } \\
\text { 9. Gas Handling } \\
\text { 10. Reservoir Insurance }\end{array}$ & $\begin{array}{r}29.2 \\
22.8 \\
143.3 \\
6.7 \\
50.8 \\
0.0 \\
187.4 \\
0.9 \\
0.0 \\
19.5\end{array}$ & $\begin{array}{l}0.0 \\
0.0 \\
3.3 \\
1.2 \\
1.0 \\
5.2 \\
4.7 \\
0.0 \\
0.0 \\
0.0\end{array}$ & $\begin{array}{l}0.62 \\
0.53 \\
3.46 \\
0.22 \\
1.68 \\
0.00 \\
5.97 \\
0.03 \\
0.00 \\
0.62\end{array}$ & $\begin{array}{l}0.00 \\
0.00 \\
1.04 \\
0.39 \\
0.32 \\
1.66 \\
1.45 \\
0.00 \\
0.00 \\
0.00\end{array}$ & $\begin{array}{l}0.62 \\
0.53 \\
4.50 \\
0.61 \\
2.00 \\
1.66 \\
7.43 \\
0.03 \\
0.00 \\
0.62\end{array}$ & $\begin{array}{l}0.0 \\
0.0 \\
0.0 \\
0.0 \\
0.0 \\
0.0 \\
0.0 \\
0.0 \\
0.0 \\
0.0\end{array}$ \\
\hline
\end{tabular}


A REPORT FROM THE IM-GEO PROGRAM

\begin{tabular}{|c|c|c|c|c|c|c|}
\hline $\begin{array}{l}\text { EOTHERMAL COST OF POWER } \\
\text { ASE CASE COSTS: }\end{array}$ & $\begin{array}{l}\text { ESTIMA } \\
\text { SITE = }\end{array}$ & asin & $\begin{array}{l}\text { UN : } \\
\text { Range }\end{array}$ & $\begin{array}{l}\text { 08-08- } \\
- \text { Powe }\end{array}$ & $\operatorname{Ran}$ & $: 1$ \\
\hline $\begin{array}{l}\text { From IM-GEO } 3.05] \\
\text { CCOUNT }\end{array}$ & $\begin{array}{l}--C o \\
C A P . \\
\$ M\end{array}$ & $\begin{array}{l}\text { OS } \\
\text { \$M/YR }\end{array}$ & $\begin{array}{l}\text { CAP. } \\
\text { PART }\end{array}$ & $\begin{array}{l}\text { Cents } \\
\text { O\&M } \\
\text { PART }\end{array}$ & $\begin{array}{l}\text { / KWhour } \\
\text { TOTAL } \\
\text { COST }\end{array}$ & TOTAL \\
\hline $\begin{array}{r}\text { TOTAL : } \\
\text { RISK FRACTION : }\end{array}$ & $\begin{array}{r}180.6 \\
5.9\end{array}$ & $\begin{array}{l}4.6 \\
0.2\end{array}$ & $\begin{array}{l}4.77 \\
0.21\end{array}$ & $\begin{array}{l}1.36 \\
0.07\end{array}$ & $\begin{array}{l}6.13 \\
0.28\end{array}$ & 0. \\
\hline $\begin{array}{l}\text { 1. Identify Reservoir } \\
\text { 2. Confirm Reservoir } \\
\text { 3. Prod./Inject. Wells } \\
\text { 4. Downhole Pumps } \\
\text { 5. Gathering Equip. } \\
\text { 6. Make-Up Wells } \\
\text { 7. Power Plant (Core) } \\
\text { 8. Brine TDS Effects } \\
\text { 9. Gas Handling } \\
\text { 10. Reservoir Insurance }\end{array}$ & $\begin{array}{r}41.0 \\
30.4 \\
13.2 \\
0.8 \\
4.4 \\
0.0 \\
85.4 \\
0.3 \\
0.0 \\
5.2\end{array}$ & $\begin{array}{l}0.0 \\
0.0 \\
0.9 \\
0.1 \\
0.1 \\
0.9 \\
2.6 \\
0.0 \\
0.0 \\
0.0\end{array}$ & $\begin{array}{l}0.83 \\
0.68 \\
0.31 \\
0.02 \\
0.14 \\
0.00 \\
2.61 \\
0.01 \\
0.00 \\
0.16\end{array}$ & $\begin{array}{l}0.00 \\
0.00 \\
0.27 \\
0.04 \\
0.03 \\
0.27 \\
0.75 \\
0.00 \\
0.00 \\
0.00\end{array}$ & $\begin{array}{l}0.83 \\
0.68 \\
0.58 \\
0.07 \\
0.16 \\
0.27 \\
3.36 \\
0.01 \\
0.00 \\
0.16\end{array}$ & \\
\hline
\end{tabular}

.PA (End of Page)

A REPORT FROM THE IM-GEO PROGRAM

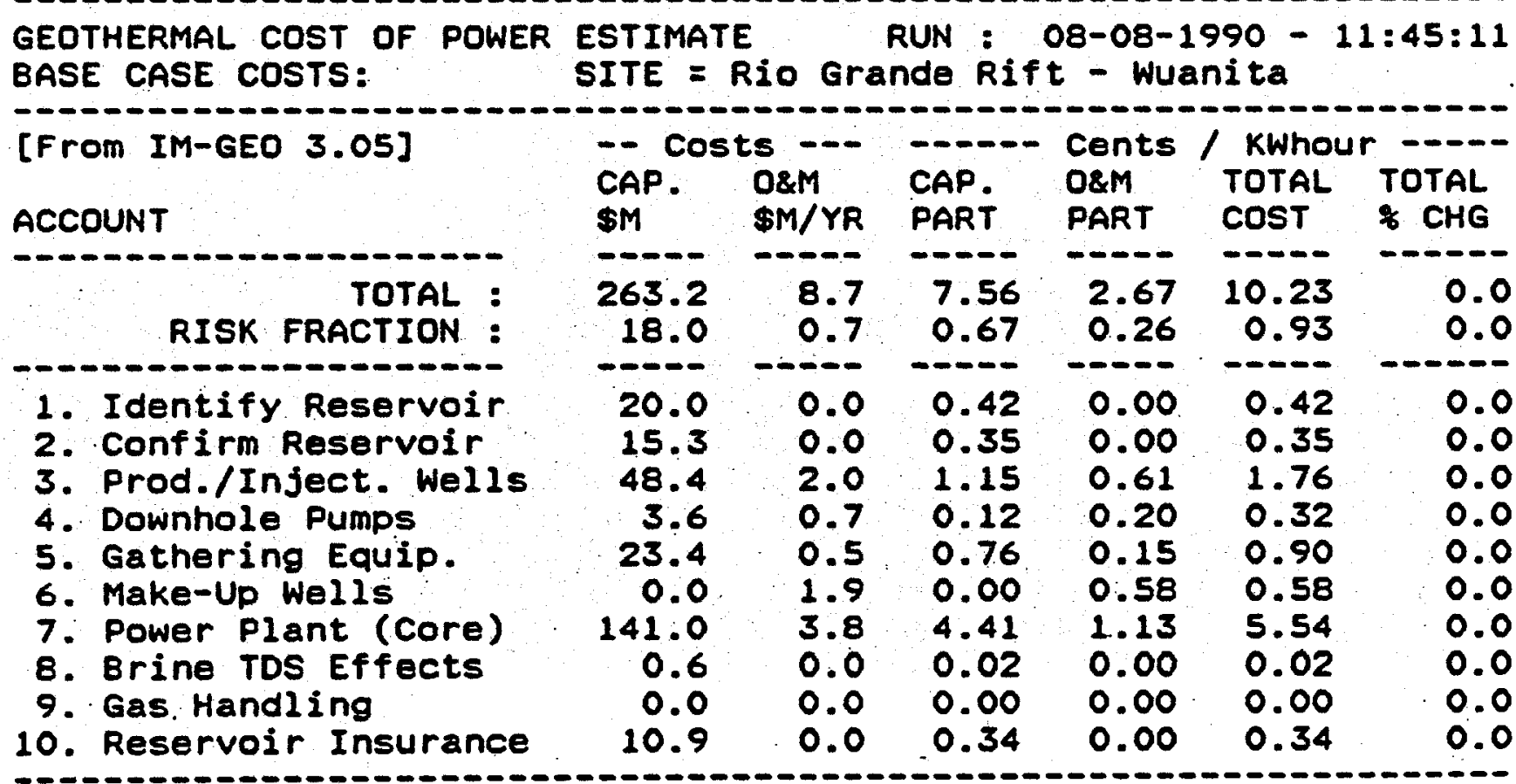


A REPORT FROM THE IM-GEO PROGRAM

\begin{tabular}{|c|c|c|c|c|c|c|}
\hline $\begin{array}{l}\text { EOTHERMAL COST OF POWER } \\
\text { ASE CASE COSTS: }\end{array}$ & $\begin{array}{l}\text { ESTIMA } \\
\text { SITE }=\end{array}$ & io $G$ & RUN : & - & as - & \\
\hline $\begin{array}{l}\text { From IM-GEO } 3.05] \\
\text { CCOUNT }\end{array}$ & $\begin{array}{l}-- \text { CO } \\
\text { CAP. } \\
S M\end{array}$ & $\begin{array}{l}\text { O\&M } \\
\text { \$M/YR }\end{array}$ & PAP. & $\begin{array}{l}\text { Cents } \\
\text { O\&M } \\
\text { PART }\end{array}$ & $\begin{array}{l}\text { KWhO } \\
\text { TOTAL } \\
\text { COST }\end{array}$ & $\begin{array}{l}\text { TOTAL } \\
\% \text { CHG }\end{array}$ \\
\hline $\begin{array}{r}\text { TOTAL : } \\
\text { RISK FRACTION : }\end{array}$ & $\begin{array}{r}135.9 \\
11.9\end{array}$ & $\begin{array}{r}4.9 \\
0.4\end{array}$ & $\begin{array}{l}3.44 \\
0.29\end{array}$ & $\begin{array}{l}1.44 \\
0.11\end{array}$ & $\begin{array}{l}4.87 \\
0.40\end{array}$ & $\begin{array}{r}0.0 \\
0.0\end{array}$ \\
\hline $\begin{array}{l}\text { 1. Identify Reservoir } \\
\text { 2. Confirm Reservoir } \\
\text { 3. Prod./Inject. Welis } \\
\text { 4. Downhole Pumps } \\
\text { 5. Gathering Equip. } \\
\text { 6. Make-Up Wells } \\
\text { 7. Power Plant (Core) } \\
\text { 8. Brine TDS Effects } \\
\text { 9. Gas Handling } \\
\text { 10. Reservoir Insurance }\end{array}$ & $\begin{array}{r}10.4 \\
27.9 \\
42.8 \\
0.0 \\
4.3 \\
0.0 \\
34.6 \\
7.1 \\
4.3 \\
4.7\end{array}$ & $\begin{array}{l}0.0 \\
0.0 \\
1.0 \\
0.0 \\
0.1 \\
2.0 \\
1.4 \\
0.2 \\
0.2 \\
0.0\end{array}$ & $\begin{array}{l}0.21 \\
0.61 \\
0.97 \\
0.00 \\
0.13 \\
0.00 \\
1.04 \\
0.21 \\
0.13 \\
0.14\end{array}$ & $\begin{array}{l}0.00 \\
0.00 \\
0.31 \\
0.00 \\
0.03 \\
0.59 \\
0.41 \\
0.05 \\
0.05 \\
0.00\end{array}$ & $\begin{array}{l}0.21 \\
0.61 \\
1.28 \\
0.00 \\
0.16 \\
0.59 \\
1.45 \\
0.26 \\
0.18 \\
0.14\end{array}$ & $\begin{array}{l}0.0 \\
0.0 \\
0.0 \\
0.0 \\
0.0 \\
0.0 \\
0.0 \\
0.0 \\
0.0 \\
0.0\end{array}$ \\
\hline
\end{tabular}

.PA (End of Page)

A REPORT FROM THE IM-GEO PROGRAM

\begin{tabular}{|c|c|c|c|c|c|c|}
\hline $\begin{array}{l}\text { EOTHERMAL COST OF POWER } \\
\text { ASE CASE COSTS: }\end{array}$ & ITE = & $0 E$ & 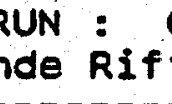 & . & 0 & \\
\hline $\begin{array}{l}\text { From IM-GEO 3.05] } \\
\text { CCOUNT }\end{array}$ & $\begin{array}{l}--C C \\
\text { CAP. } \\
\text { SM }\end{array}$ & $\begin{array}{l}\text { O\&M } \\
\$ M / Y R\end{array}$ & CAP. & $\begin{array}{l}\text { Cents } \\
\text { D\&M } \\
\text { PART }\end{array}$ & $\begin{array}{l}\text { KWhOI } \\
\text { TOTAL } \\
\text { COST }\end{array}$ & $\begin{array}{l}\text { TOTAL } \\
\% \text { CHG }\end{array}$ \\
\hline $\begin{array}{r}\text { TOTAL : } \\
\text { RISK FRACTION : }\end{array}$ & & $\begin{array}{r}20.5 \\
2.8\end{array}$ & $\begin{array}{l}7.00 \\
2.83\end{array}$ & $\frac{1}{3}$ & $\begin{aligned} 23.6 \\
3.5\end{aligned}$ & $\begin{array}{l}.0 \\
.0\end{array}$ \\
\hline $\begin{array}{l}\text { 1. Identify Reservoir } \\
\text { 2. Confirm Reservoir } \\
\text { 3. Prod. I Inject. Wells } \\
\text { 4. Downhole Pumps } \\
\text { 5. Gathering Equip. } \\
\text { 6. Make-Up Wells } \\
\text { 7. Power Plant (Core) } \\
\text { 8. Brine TDS Effects } \\
\text { 9. Gas Handling } \\
\text { 0. Reservoir Insurance }\end{array}$ & $\begin{array}{r}21.6 \\
16.5 \\
161.1 \\
10.2 \\
88.8 \\
0.0 \\
242.8 \\
1.1 \\
0.0 \\
25.2\end{array}$ & $\begin{array}{l}0.0 \\
0.0 \\
5.2 \\
1.9 \\
1.8 \\
5.7 \\
5.9 \\
0.0 \\
0.0\end{array}$ & & $\begin{array}{l}0.0 \\
0.0 \\
1.6 \\
0.6 \\
0.5 \\
1.8 \\
1.8 \\
0.0 \\
0.0 \\
0.0\end{array}$ & $\begin{array}{l}5 . \\
0 . \\
3 . \\
9 .\end{array}$ & $\begin{array}{l}0.0 \\
0.0 \\
0.0 \\
0.0 \\
0.0 \\
0.0 \\
0.0 \\
0.0 \\
0.0 \\
0.0\end{array}$ \\
\hline
\end{tabular}


A REPORT FROM THE IM-GEO PROGRAM

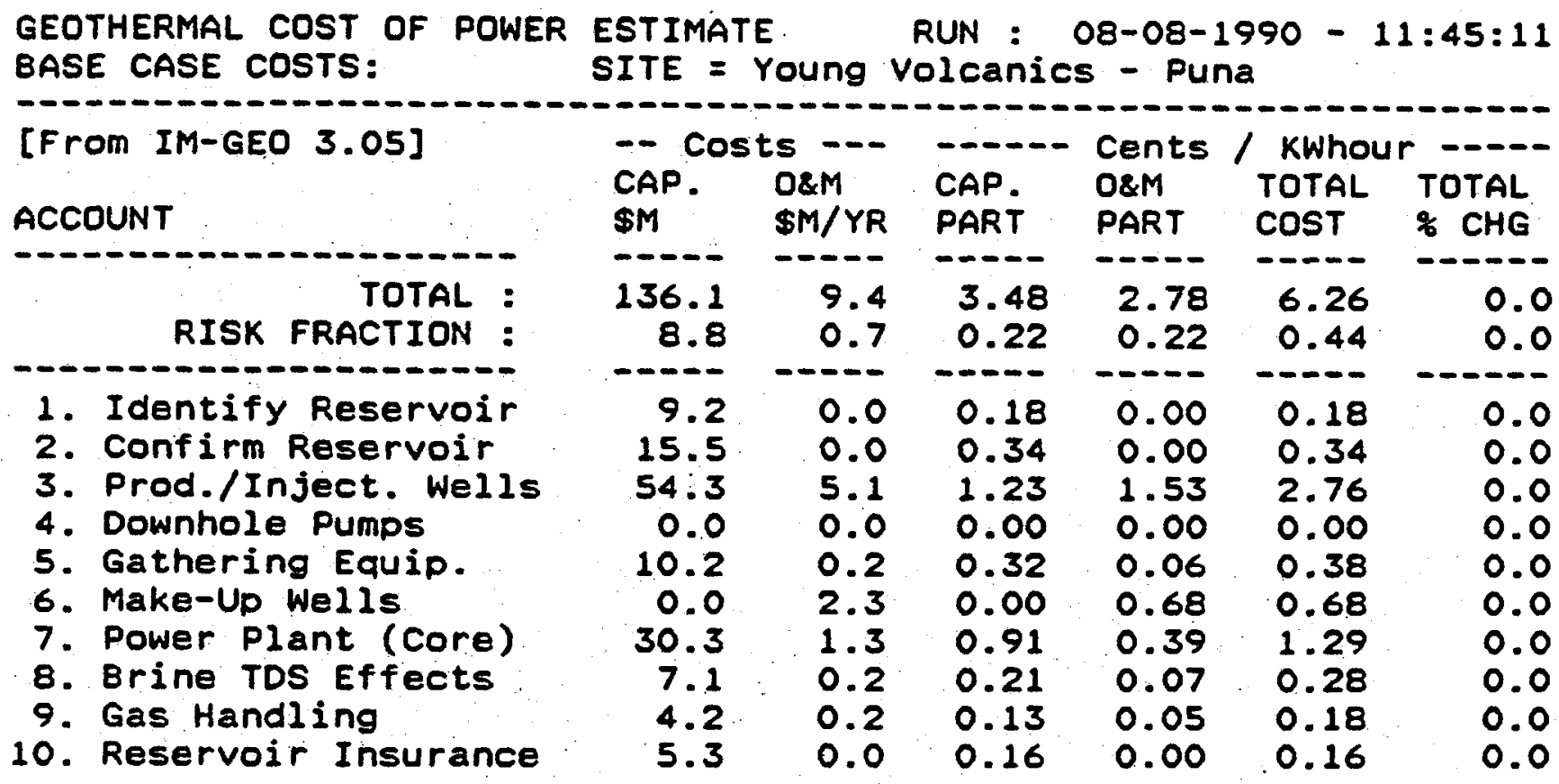

.PA (End of Page)

A REPORT FROM THE IM-GEO PROGRAM

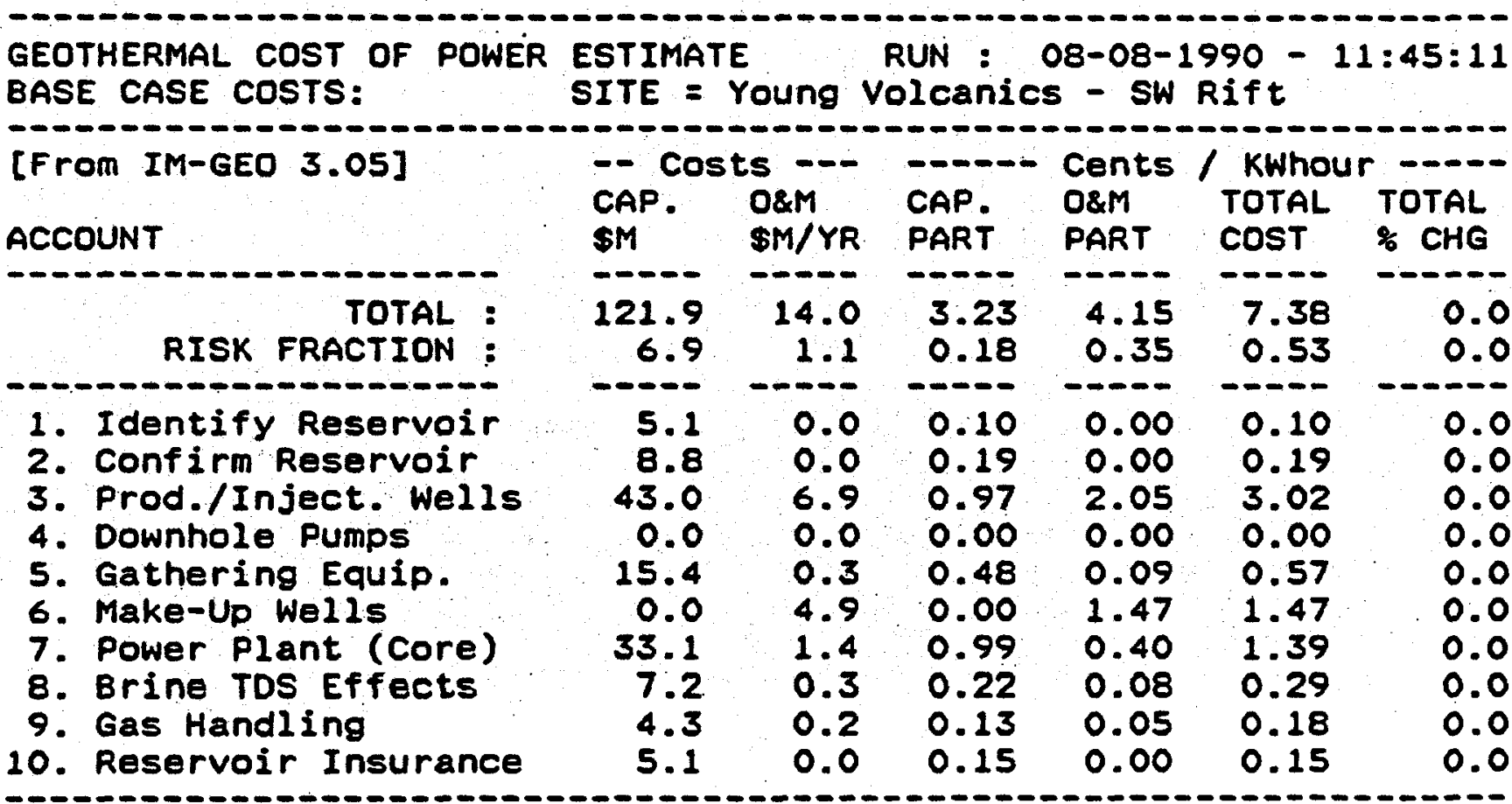


INCREASED RATE OF TECHNOLOGY IMPROVEMENT 
GEOTHERMAL COST OF POWER ESTIMATE

RUN : 08-02-1990-19:02:08 New Techology Costs: Imperial Valley - Brawley

\begin{tabular}{|c|c|c|c|c|}
\hline $\begin{array}{l}\text { [From IMGEO Model] } \\
\text { ACCOUNT }\end{array}$ & $\begin{array}{l}\text { Capital } \\
\text { Cost, } \\
\$\end{array}$ & $\begin{array}{l}O \& M \\
\operatorname{Cos} t \\
\$ / Y r\end{array}$ & $\begin{array}{l}\text { Capital } \\
\text { Part of } \\
\text { System }\end{array}$ & $\begin{array}{l}\text { Total } \\
\text { Busbar } \\
\text { Cost }\end{array}$ \\
\hline $\begin{array}{r}\text { TOTAL : } \\
\text { RISK FRACTION : }\end{array}$ & $\begin{array}{r}110.0 \\
5.7\end{array}$ & $\begin{array}{l}6.8 \\
0.3\end{array}$ & $\begin{array}{l}29.8 \\
1.5\end{array}$ & $\begin{array}{r}49.5 \\
2.4\end{array}$ \\
\hline $\begin{array}{l}\text { 1. Identify Reservoir } \\
\text { 2. Confirm Reservoir } \\
\text { 3. Prod./Inject. Wells } \\
\text { 4. Downhole Pumps } \\
\text { 5. Gathering Equip. } \\
\text { 6. Make-Up Wells. } \\
\text { 7. Power Plant (Core) } \\
\text { 8. Brine TDS Effects } \\
\text { 9. Gas Handling } \\
\text { 10. Reservoir Insurance }\end{array}$ & $\begin{array}{r}4.5 \\
14.3 \\
21.6 \\
0.0 \\
5.3 \\
0.0 \\
41.6 \\
15.3 \\
3.1 \\
4.3\end{array}$ & $\begin{array}{l}0.0 \\
0.0 \\
1.7 \\
0.0 \\
0.2 \\
0.0 \\
2.2 \\
2.5 \\
0.2 \\
0.0\end{array}$ & $\begin{array}{r}0.9 \\
3.2 \\
4.9 \\
0.0 \\
1.6 \\
0.0 \\
12.4 \\
4.6 \\
0.9 \\
1.3\end{array}$ & $\begin{array}{r}0.5 \\
3.2 \\
10.0 \\
0.0 \\
2.3 \\
0.0 \\
18.7 \\
11.6 \\
1.5 \\
1.3\end{array}$ \\
\hline
\end{tabular}

IM-GEO: SENSITIVITY FACTORS IN EFFECT 08-02-1990 - 19:02:08

R\&D Achumt: Wildcat success Ratio

R\&D Achvmt: Confirm. Success Ratio

R\&D Achumt: Testing Costs, Confirm

R\&D Achvmt: Dry Holes / Producer

R\&D Achumt: Testing Costs, Producer

R\&D Achumt: BASE Cost, Average Well

R\&D Achumt: Cap.Cost; Deep Well Pump

R\&D Achumt: O\&M Cost. Deep Well Pump

R\&D Achumt: Workover Interval, Prod.

R\&D Achvmt: Workover Interval, Injc.

R\&D Achumt: FLASH Plant - Efficiency

R\&D Achumt: FLASH Plant - Capital cost

R\&D Achumt: BINARY Plant - Efficiency.

R\&D Achumt: BINARY Plant - Capital cost

R\&D Achumt: TDS-Clarifier. Capital cost

R\&D Achumt: TDS-Clarifier, O\&M Cost
R\&D Achumt: H2S Treatment, Capital cost

$\begin{array}{ll}: & 1.20 \\ : & 1.25 \\ : & 0.75 \\ : & 0.85 \\ : & 0.75 \\ : & 0.80 \\ : & 0.75 \\ : & 0.80 \\ : & 0.50 \\ : & 0.50 \\ : & 1.05 \\ : & 0.95 \\ : & 1.20 \\ : & 0.76 \\ : & 0.90 \\ : & 0.80 \\ : & 0.80\end{array}$

Regional Weights = Regional Capacity

(End of Page)

GEOTHERMAL COST OF POWER ESTIMATE New Techology Costs: B \& R - Roosevelt HS.

RUN: 08-02-1990-19:02:08.

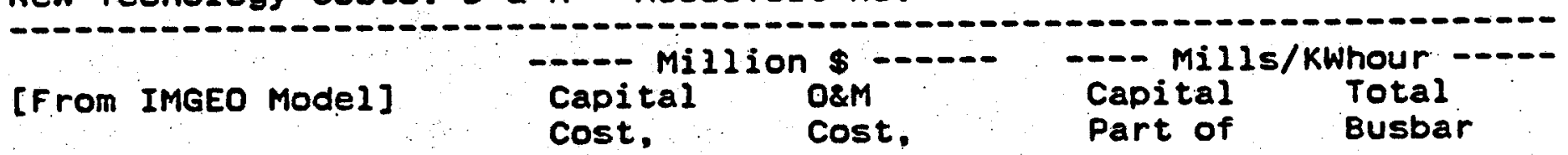




\begin{tabular}{|c|c|c|c|c|}
\hline ACCOUNT & $\$$ & $\$ / Y r$ & System & $\cos t$ \\
\hline $\begin{array}{r}\text { TOTAL : } \\
\text { RISK FRACTION : }\end{array}$ & $\begin{array}{r}83.0 \\
3.8\end{array}$ & $\begin{array}{r}3.3 \\
-0.1\end{array}$ & $\begin{array}{r}22.5 \\
1.0\end{array}$ & $\begin{array}{r}31.9 \\
0.8\end{array}$ \\
\hline $\begin{array}{l}\text { 1. Identify Reservoir } \\
\text { 2. Confirm Reservoir } \\
\text { 3. Prod./Inject. Wells } \\
\text { 4. Downhole Pumps } \\
\text { 5. Gathering Equip. } \\
\text { 6. Make-Up Wells } \\
\text { 7. Power Plant (Core) } \\
\text { 8. Brine TDS Effects } \\
\text { 9. Gas Handling } \\
\text { 10. Reservoir Insurance }\end{array}$ & $\begin{array}{r}8.7 \\
15.4 \\
4.0 \\
0.0 \\
2.0 \\
0.0 \\
40.9 \\
6.5 \\
2.7 \\
2.8\end{array}$ & $\begin{array}{l}0.0 \\
0.0 \\
0.6 \\
0.0 \\
0.0 \\
0.1 \\
2.2 \\
0.2 \\
0.1 \\
0.0\end{array}$ & $\begin{array}{r}1.7 \\
3.4 \\
0.9 \\
0.0 \\
0.6 \\
0.0 \\
12.2 \\
1.9 \\
0.8 \\
0.8\end{array}$ & $\begin{array}{r}1.7 \\
3.4 \\
2.7 \\
0.0 \\
0.8 \\
0.4 \\
18.5 \\
2.4 \\
1.2 \\
0.8\end{array}$ \\
\hline
\end{tabular}

\section{IM-GEO: SENSITIVITY FACTORS IN EFFECT 08-02-1990 - 19:02:08}

R\&D Achumt: Wildcat Success Ratio

R\&D Achumt: Confirm. Success Ratio

R\&D Achumt: Testing Costs, Confirm

R\&D Achvmt: Dry Holes / Producer

R\&D Achumt: Testing Costs, Producer

R\&D Achumt: BASE Cost, Average Well

R\&D Achumt: Cap.Cost, Deep Well Pump

R\&D Achvmt: O\&M Cost, Deep Well Pump

R\&D Achvmt: Workover Interval, Prod.

RED Achvmt: Workover Interval, Injc.

R\&D Achumt: FLASH Plant - Efficiency

R\&D Achumt: FLASH Plant - Capital cost

R\&D Achvmt: BINARY Plant - Efficiency

R\&D Achvmt: BINARY Plant - Capital Cost

R\&D AChvmt: TDS-Clarifier, Capital cost

R\&D Achumt: TDS-Clarifier, O\&M Cost
R\&D Achumt: H2S Treatment, Capital Cost

$: 1.20$
$: \quad 1.25$
$: \quad 0.75$
$: 0.85$
$: \quad 0.75$
$: 0.80$
$: 0.75$
$: \quad 0.80$
$: 0.50$
$: \quad 0.50$
$: 0.95$
$: \quad 1.20$
$: 0.76$
$: 0.90$
$: 0.80$
$: \quad 0.80$

Regional Weights $=$ Regional Capacity

(End of Page)

GEOTHERMAL COST OF POWER ESTIMATE

New Techology Costs: B \& R - Cove fort

RUN: $08-02-1990-19: 02: 08$

\begin{tabular}{|c|c|c|c|c|}
\hline $\begin{array}{l}\text { [From IMGEO Model] } \\
\text { ACCOUNT }\end{array}$ & $\begin{array}{l}\text { Capital } \\
\text { Cost. } \\
\$\end{array}$ & $\begin{array}{l}\text { D\&M } \\
\text { Cost } \\
\$ / Y r\end{array}$ & $\begin{array}{l}\text { Capital } \\
\text { Part of } \\
\text { System }\end{array}$ & $\begin{array}{l}\text { Total } \\
\text { Busbar } \\
\text { Cost }\end{array}$ \\
\hline $\begin{array}{r}\text { TOTAL : } \\
\text { RISK FRACTION : }\end{array}$ & $\begin{array}{r}124.6 \\
11.6\end{array}$ & $\begin{array}{l}5.7 \\
0.1\end{array}$ & $\begin{array}{r}37.2 \\
4.6\end{array}$ & $\begin{array}{l}54.9 \\
5.6\end{array}$ \\
\hline $\begin{array}{l}\text { 1. Identify Reservoir } \\
\text { 2. Confirm Reservoir } \\
\text { 3. Prod./Inject. Wells } \\
\text { 4. Downhole Pumps } \\
\text { 5. Gathering Equip. }\end{array}$ & $\begin{array}{r}5.9 \\
8.2 \\
18.9 \\
1.3 \\
9.6\end{array}$ & $\begin{array}{l}0.0 \\
0.0 \\
0.8 \\
0.2 \\
0.2\end{array}$ & $\begin{array}{l}1.3 \\
1.9 \\
4.6 \\
0.4 \\
3.2\end{array}$ & $\begin{array}{l}1.3 \\
1.5 \\
7.2 \\
1.2 \\
3.8\end{array}$ \\
\hline
\end{tabular}


6. Make-Up Wells

7. Power Plant (Core)

8. Brine TDS Effects

9. Gas Handling

10: Reservoir Insurance

0.0
75.1
0.4
0.0
5.3

0.6

3.8

0.0

0.0

0.0
0.0

24.0

0.1

0.0

1.7
2.0

35.6

0.1

0.0

\section{IM-GEO: SENSITIVITY FACTORS IN EFFECT 08-02-1990 - 19:02:08}

R\&D Achumt: Wildcat Success Ratio

R\&D Achumt: Confirm. Success Ratio

R\&D Achvmt: Testing Costs, Confirm

R\&D Achumt: Dry Holes / Producer

R\&D Achumt: Testing Costs, Producer

R\&D Achumt: BASE Cost, Average Well

R\&D Achumt: Cap.Cost, Deep Well Pump

R\&D Achumt: O\&M Cost, Deep. Well Pump

R\&D Achumt: Workover Interval, Prod.

R\&D Achvmt: Workover Interval, Injc.

R\&D Achvmt: FLASH Plant - Efficiency

R\&D Achumt: FLASH Plant - Capital cost

R\&D Achvmt: BINARY Plant - Efficiency

R\&D Achumt: BINARY Plant - Capital Cost

R\&D Achumt: TDS-Clarifier, Capital cost

R\&D Achumt: TDS-Clarifier, O\&M Cost

R\&D Achumt: H2S Treatment, Capital cost $\begin{array}{ll}: & 1.20 \\ : & 1.25 \\ : & 0.75 \\ : & 0.85 \\ : & 0.75 \\ : & 0.80 \\ : & 0.75 \\ : & 0.80 \\ : & 0.50 \\ : & 0.50 \\ : & 1.05 \\ : & 0.95 \\ : & 1.20 \\ : & 0.76 \\ : & 0.90 \\ : & 0.80 \\ : & 0.80\end{array}$

Regional Weights = Regional Capacity

(End of Page)

GEOTHERMAL COST OF POWER ESTIMATE New Techology Costs: Cascades - Newberry

RUN: $08-02-1990-19: 02: 08$

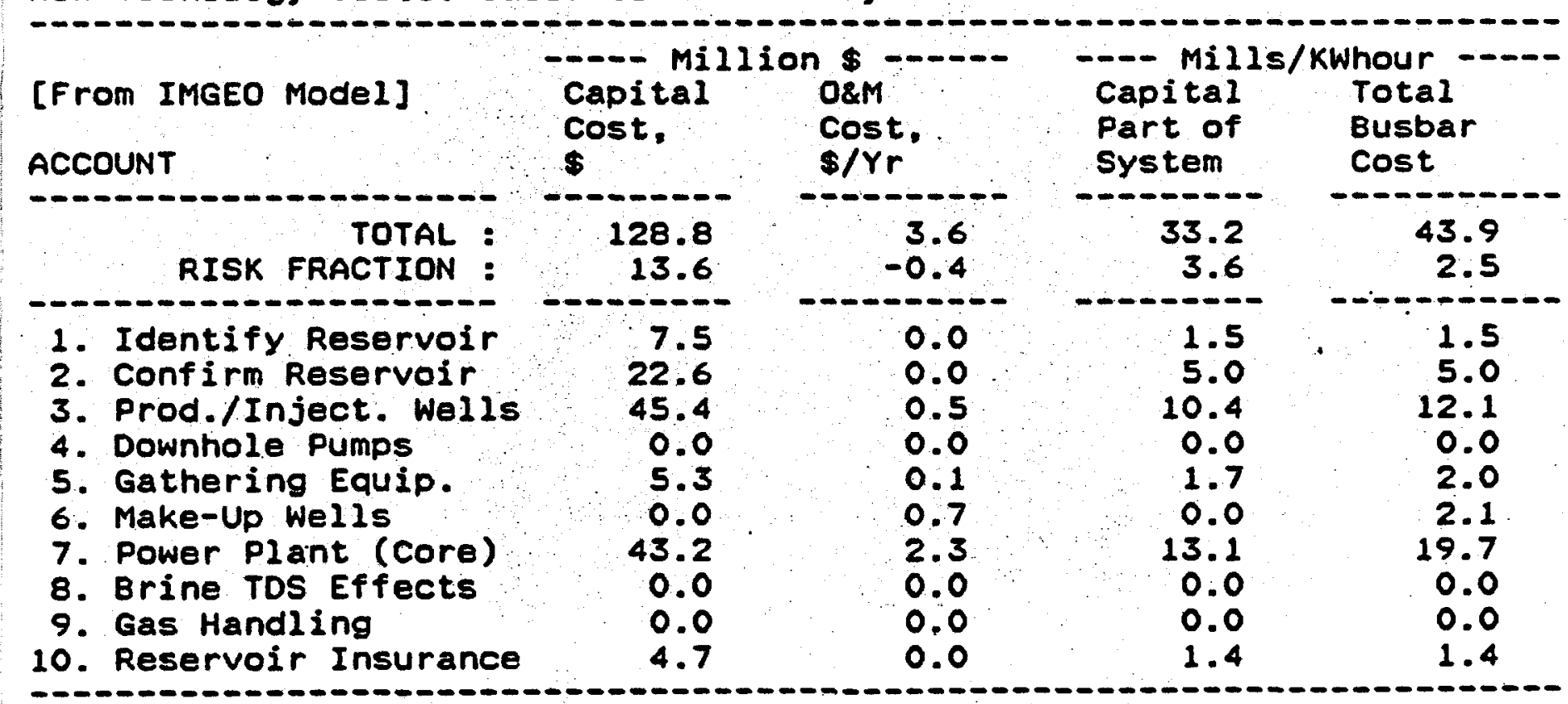

IM-GEO: SENSITIVITY FACTORS IN EFFECT 08-02-1990- 19:02:08 
R\&D Achvmt: Confirm. Success Ratio

R\&D Achumt: Testing Costs, Confirm

R\&D Achvmt: Dry Holes / Producer

R\&D Achumt: Testing Costs, Producer

0.85

0.75

0.80

R\&D Achumt: BASE cost, Average Well

0.75

0.80

0.50

0.50

R\&D Achvmt: o\&M Cost, Deep Well Pump

1.05

0.95

1.20

0.76

R\&D Achumt: TDS-Clarifier, Capital Cost :
R\&D Achumt: TDS-Clarifier, O\&M Cost
R\&D Achumt: H2S Treatment, Capital Cost : 0.80
0.80

R\&D Achumt: TDS-Clarifier, Capital Cost :
R\&D Achumt: TDS-Clarifier, O\&M Cost
R\&D Achumt: H2S Treatment, Capital Cost : 0.80
0.80

R\&D Achvmt: Workover Interval, Injc.

R\&D Achumt: FLASH Plant - Capital cost

R\&D Achumt: BINARY Plant - Efficiency

R\&D Achumt: TDS-Clarifier, Capital Cost :
R\&D Achumt: TDS-Clarifier, O\&M Cost
R\&D Achumt: H2S Treatment, Capital Cost : 0.80
0.80

Regional Weights = Regional Capacity

(End of Page)

GEOTHERMAL COST OF POWER ESTIMATE New Techology costs: Y Vol. - Long Valley HT

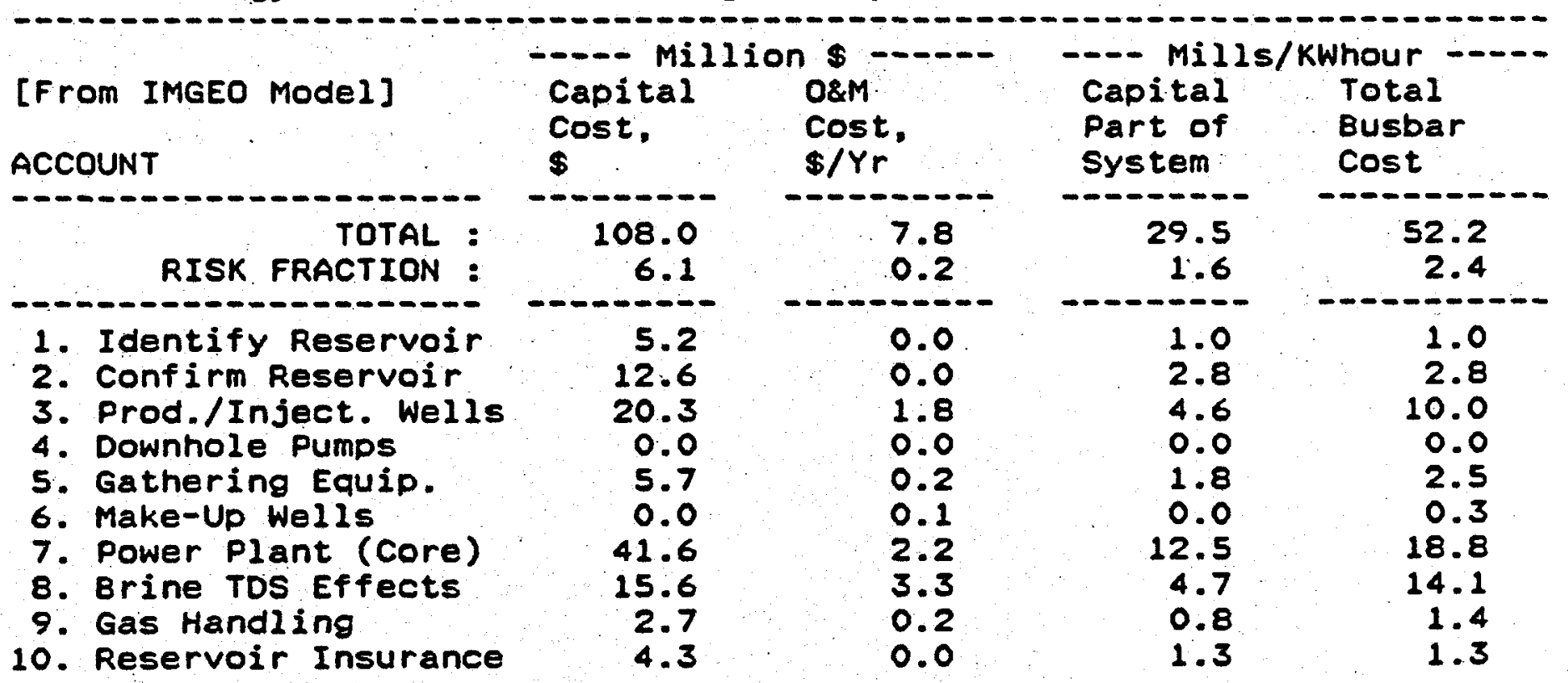

\section{IM-GEO: SENSITIVITY FACTORS IN EFFECT 08-02-1990 - 19:02:08}

R\&D Achumt: Wildcat Success Ratio

R\&D Achvmt: Confirm. Success Ratio

R\&D Achumt: Testing Costs, Confirm

R\&D Achumt: Dry Holes / Producer

R\&D Achumt: Testing Costs, Producer

R\&D AChumt: BASE Cost, Average Well

R\&D Achumt: Cap.Cost, Deep Well Pump

R\&D Achumt: O\&M Cost, Deep Well Pump

R\&D Achumt: Workover Interval, Prod.

R\&D Achumt: Workover Interval, Injc.

R\&D Achumt: FLASH Plant - Efficiency
RUN: 08-02-1990-19:02:08 
R\&D Achumt: FLASH Plant - Capital Cost : 0.95
R\&D Achumt: BINARY Plant - Efficiency : 1.20
R\&D AChumt: BINARY Plant - Capital Cost : 0.76
R\&D Achumt: TDS-Clarifier, Capital cost : 0.90
R\&D AChvmt: TDS-Clarifier, O\&M Cost
R\&D Achumt: H2S Treatment, Capital cost : 0.80

Regional Weights = Regional Capacity

(End of Page)

GEOTHERMAL COST OF POWER ESTIMATE New Techology Costs: Y Vol. - Long Valley HT

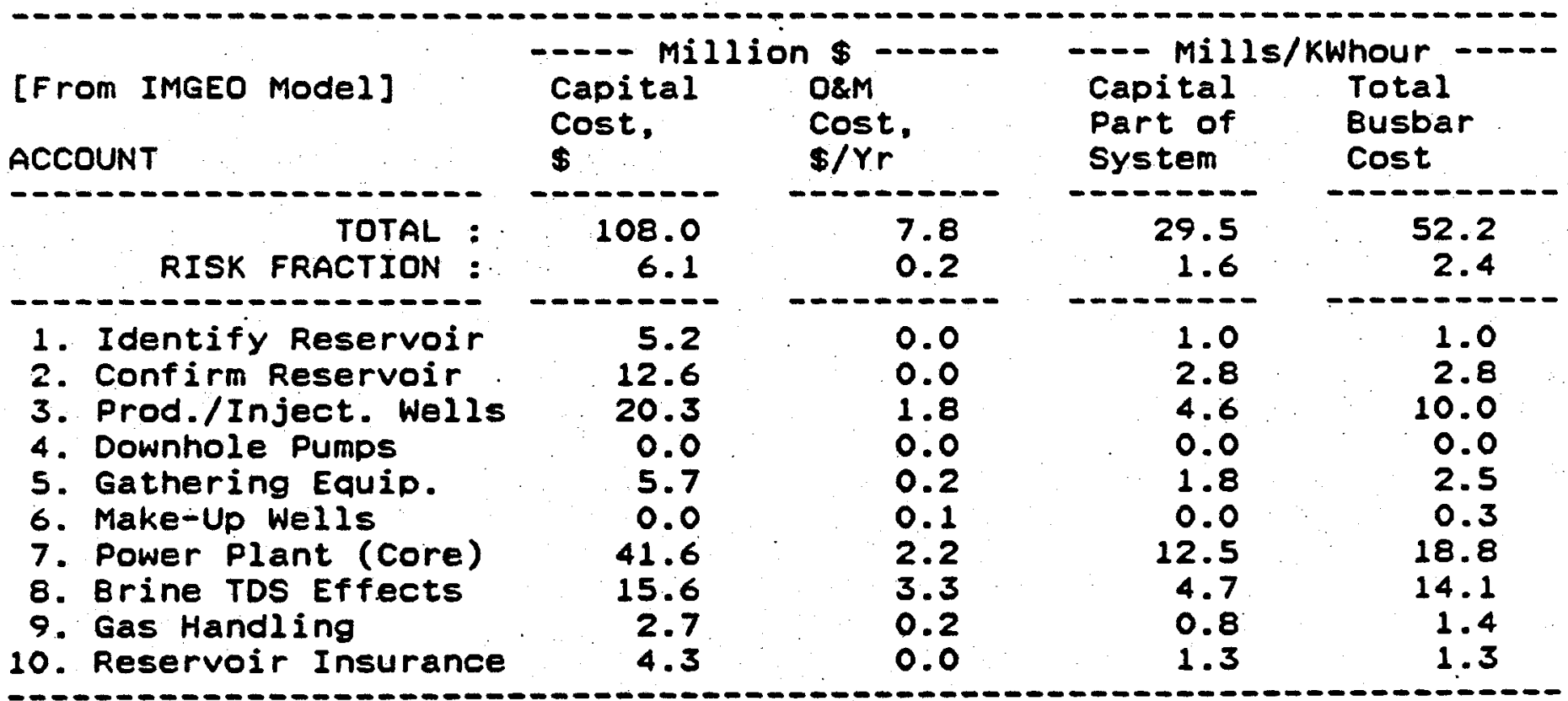

IM-GEO: SENSITIVITY FACTORS IN EFFECT 08-02-1990 - 19:02:08

R\&D Achumt: Wildcat Success Ratio

R\&D Achvmt: Confirm. Success Ratio

R\&D Achumt: Testing Costs, Confirm

R\&D Achvmt: Dry Holes / Producer

R\&D Achvmt: Testing Costs, Producer

R\&D Achvmt: BASE Cost, Average Well

R\&D Achumt: Cap.Cost, Deep Well Pump

R\&D Achvmt: O\&M Cost, Deep Well Pump

R\&D Achumt: Workover Interval, Prod.

R\&D Achvint: Workover Interval, Injc.

R\&D Achvmt: FLASH Plant - Efficiency

R\&D Achvmt: FLASH Plant - Capital Cost

R\&D Achumt: BINARY Plant - Efficiency

R\&D Achumt: BINARY Plant - Capital cost

R\&D Achumt: TOS-Clarifier.: Capital Cost

R\&D Achvmt: TOS-Clarifier, O\&M Cost

R\&D Achumt: H2S Treatment, Capital cost
RUN: 08-02-1990-19:02:08 
GEOTHERMAL COST OF POWER ESTIMATE New Techology Costs: Y. Vol.- Buckeye HS

RUN: $08-02-1990-18: 47: 58$

\begin{tabular}{|c|c|c|c|c|}
\hline $\begin{array}{l}\text { [From IMGEO Model] } \\
\text { ACCOUNT }\end{array}$ & $\begin{array}{l}\text { Capital } \\
\text { Cost. } \\
\$\end{array}$ & $\begin{array}{l}\text { O\&M } \\
\text { Cost } \\
\$ / Y r\end{array}$ & $\begin{array}{l}\text { Capital } \\
\text { Part of } \\
\text { System }\end{array}$ & $\begin{array}{l}\text { Total } \\
\text { Busbar } \\
\text { Cost }\end{array}$ \\
\hline $\begin{array}{r}\text { TOTAL : } \\
\text { RISK FRACTION : }\end{array}$ & $\begin{array}{l}582.3 \\
102.1\end{array}$ & $\begin{array}{c}20.7 \\
2.1\end{array}$ & $\begin{array}{r}173.2 \\
34.9\end{array}$ & $\begin{array}{r}240.3 \\
43.7\end{array}$ \\
\hline $\begin{array}{l}\text { 1. Identify Reservoir } \\
\text { 2. Confirm Reservoir } \\
\text { 3. Prod./Inject. Wells } \\
\text { 4. Downhole Pumps } \\
\text { 5. Gathering Equip. } \\
\text { 6. Make-Up Wells } \\
\text { 7. Power Plant (Core) } \\
\text { 8. Brine TDS Effects } \\
\text { 9. Gas Handling } \\
\text { 10. Reservoir Insurance }\end{array}$ & $\begin{array}{r}5.4 \\
13.3 \\
235.1 \\
7.4 \\
92.2 \\
0.0 \\
201.8 \\
0.2 \\
0.0 \\
26.8\end{array}$ & $\begin{array}{l}0.0 \\
0.0 \\
2.9 \\
1.4 \\
1.8 \\
6.0 \\
8.6 \\
0.0 \\
0.0 \\
0.0\end{array}$ & $\begin{array}{r}1.2 \\
3.2 \\
58.9 \\
2.5 \\
31.6 \\
0.0 \\
66.7 \\
0.1 \\
0.0 \\
8.9\end{array}$ & $\begin{array}{r}1.2 \\
3.2 \\
68.3 \\
7.3 \\
37.7 \\
19.7 \\
93.9 \\
0.1 \\
0.0 \\
8.9\end{array}$ \\
\hline
\end{tabular}

\section{IM-GEO: SENSITIVITY FACTORS IN EFFECT 08-02-1990 - 18:47:58}

\section{R\&D Achvmt: Wildcat Success Ratio}

R\&D Achvmt: Confirm. Success Ratio

R\&D Achumt: Testing Costs, Confirm

R\&D Achvmt: Dry Holes / Producer

R\&D Achumt: Testing Costs, Producer

R\&D Achumt: BASE Cost, Average Well

R\&D Achvmt: Cap.Cost. Deep Well Pump

R\&D Achvmt: 0\&M Cost, Deep Well Pump

R\&D Achumt: Workover Interval, Prod.

R\&D Achvmt: Workover Interval. Injc.

R\&D Achumt: FLASH Plant - Efficiency
R\&D Achumt: FLASH Plant - Capital Cost

R\&D Achumt: BINARY Plant - Efficiency

R\&D AChumt: BINARY Plant - Capital Cost

$: 1.20$
$: 1.25$
$: 0.75$
$: 0.85$
$: 0.75$
$: 0.80$
$: 0.75$
$: 0.80$
$: 0.50$
$: 0.50$
$: 1.05$
$: 0.95$
$: 1.20$
$: 0.76$

Regional Weights = Regional Capacity

(End of Page)

GEOTHERMAL COST OF POWER ESTIMATE

RUN: $08-02-1990-18: 47: 58$ New Techology Costs: Imperial Valley - Glamis

[From IMGEO Model]

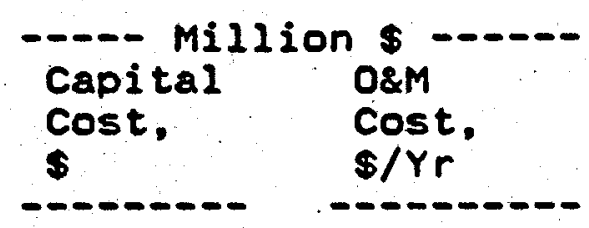

\begin{tabular}{ll} 
& \\
Capital Mills/KWhour & Total \\
Part of & Busbar \\
System & Cost \\
\hline
\end{tabular}




\begin{tabular}{rr}
93.4 & 1.8 \\
\hline 4.5 & 0.0 \\
11.0 & 0.0 \\
172.5 & 2.6 \\
7.0 & 1.4 \\
76.2 & 1.5 \\
0.0 & 0.3 \\
157.4 & 6.9 \\
0.9 & 0.0 \\
0.0 & 0.0 \\
20.7 & 0.0
\end{tabular}

.

31.4

38.4

1. Identify Reservoir

2. Confirm Reservoir

3. Prod./Inject. Wells

4. Downhole Pumps

5. Gathering Equip.

6. Make-Up Wells

7. Power Plant (Core)

8. Brine TDS Effects

9. Gas Handling

10. Reservoir Insurance

20.7

IM-GEO: SENSITIVITY FACTORS IN EFFECT 08-02-1990 - 18:47:58

R\&D Achvmt: Wildcat Success Ratio

R\&D Achvmt: Confirm. Success Ratio

R\&D Achumt: Testing Costs, Confirm

R\&D Achumt: Dry Holes / Producer

R\&D Achumt: Testing Costs, Producer

R\&D Achumt: BASE Cost, Average Well

R\&D Achivmt: Cap.Cost, Deep Well Pump

R\&D Achumt: O\&M Cost, Deep Well Pump

R\&D Achumt: Workover Interval, Prod.

R\&D Achumt: Workover Interval, Inje.

R\&D Achumt: FLASH Plant - Efficiency

R\&D Achvmt: FLASH Plant - Capital Cost

R\&D Achumt: BINARY Plant - Efficiency

R\&D AChvmt: BINARY Plant - Capital cost

$\begin{array}{ll}: & 1.20 \\ : & 1.25 \\ : & 0.75 \\ : & 0.85 \\ : & 0.75 \\ : & 0.80 \\ : & 0.75 \\ : & 0.80 \\ : & 0.50 \\ : & 0.50 \\ : & 1.05 \\ : & 0.95 \\ : & 1.20 \\ : & 0.76\end{array}$

Regional Weights = Regional Capacity

(End of Page)

GEOTHERMAL COST OF POWER ESTIMATE RUN: 08-02-1990 - 18:47:58 New Techology Costs: $B$ \& $R$ - Hot Springs Ranch

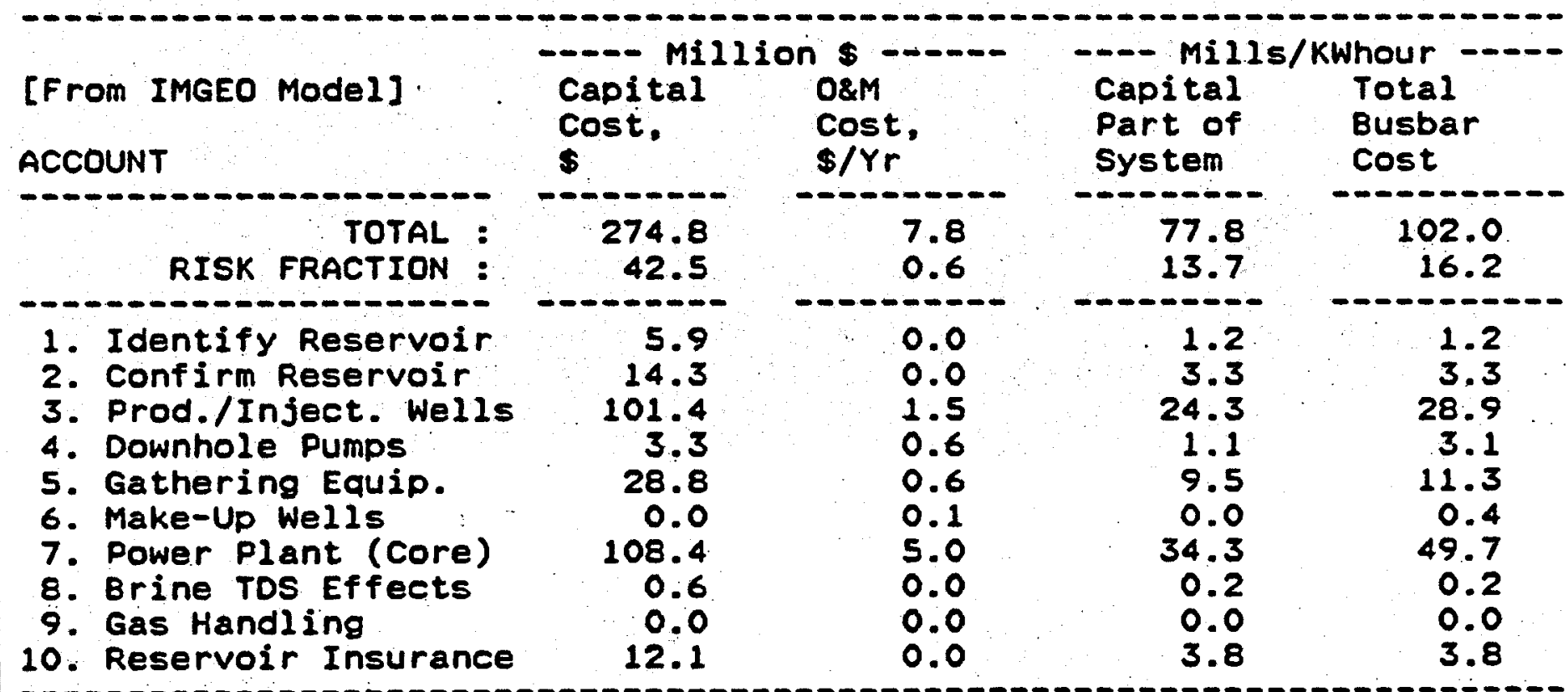


IM-GEO: SENSITIVITY FACTORS IN EFFECT 08-02-1990 - 18:47:58

R\&D Achvmt: Wildcat Success Ratio

R\&D Achvmt: Confirm. Success Ratio

R\&D Achumt: Testing Costs, Confirm

R\&D Achumt: Dry Holes / Producer

R\&D Achumt: Testing Costs, Producer

R\&D Achumt: BASE Cost, Average Well

R\&D Achumt: Cap.Cost, Deep Well Pump

R\&D Achumt: O\&M Cost, Deep Well Pump

R\&D Achvint: Workover Interval, Prod

R\&D Achvmt: Workover Interval, Inje.

R\&D Achumt: FLASH Plant - Efficiency : 1.05

RED Achvmt: FLASH Plant - Capital Cost : 0.95

R\&D Achvmt: BINARY Plant - Efficiency : 1.20

R\&D Achvmt: BINARY Plant - Capital Cost : 0.76

Regional Weights $=$ Regional Capacity

(End of Page)

GEOTHERMAL COST OF POWER ESTIMATE

RUN: $08-02-1990-18: 47: 58$

New Techology Costs: Basin \& Range - Wendell

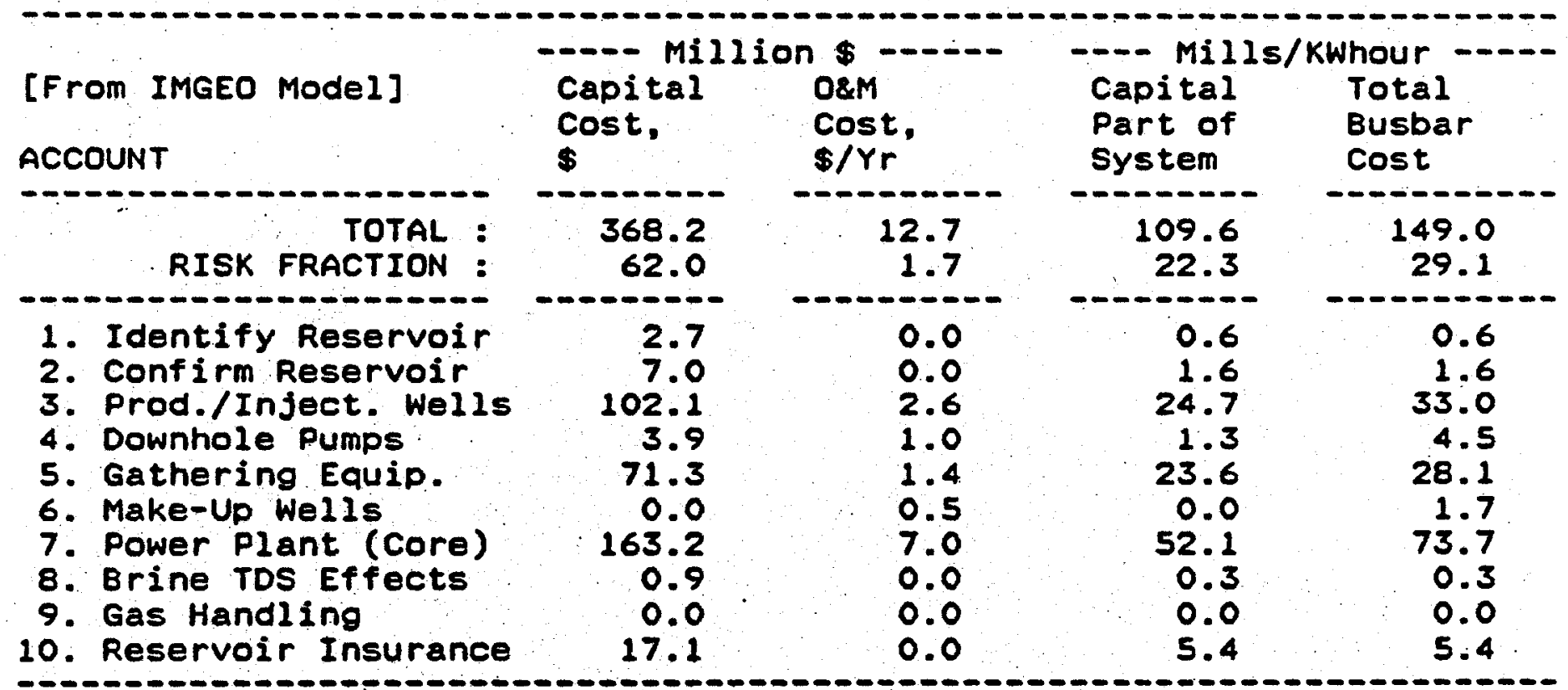

IM-GEO: SENSITIVITY FACTORS IN EFFECT 08-02-1990 - 18:47:58

R\&D Achumt: Wildcat Success Ratio

R\&D Achumt: Confirm. Success Ratio

R\&D Achumt: Testing costs, Confirm.

R\&D Achumt: Dry Holes / Producer

R\&D Achvmt: Testing Costs, Producer

R\&D Achumt: BASE Cost, Average Well

R\&D Achimt: Cap.Cost, Deep Well Pump

R\&D Achumt: O\&M Cost, Deep Well Pump

R\&D Achvmt: Workover Interval, Prod.

R\&D Achumt: Workover Interval, Injc.

$: 1.20$
$: \quad 1.25$
$: 0.75$
$: 0.85$
$: 0.75$
$: 0.80$
$: 0.75$
$: 0.80$
$: 0.50$
0.50




R\&D Achumt: FLASH Plant - Efficiency : 1.05
R\&D Achumt: FLASH Plant - Capital Cost : 0.95
R\&D AChumt: BINARY Plant - Efficiency : 1.20
R\&D Achumt: BINARY Plant - Capital Cost : 0.76

Regional Weights = Regional Capacity

(End of Page)

GEOTHERMAL COST OF POWER ESTIMATE New Techology Costs: Cascades - Kelly HS

RUN: $08-02-1990-18: 47: 58$

\begin{tabular}{|c|c|c|c|c|}
\hline $\begin{array}{l}\text { [From IMGEO Model] } \\
\text { ACCOUNT }\end{array}$ & $\begin{array}{l}\text { Capital } \\
\text { Cost. } \\
\$\end{array}$ & $\begin{array}{l}\$ 1-- \\
\operatorname{OsM} \\
\cos t \\
\$ / Y r\end{array}$ & $\begin{array}{l}\text { Capital } \\
\text { Part of } \\
\text { System }\end{array}$ & $\begin{array}{l}\text { Whour } \\
\text { Total } \\
\text { Busbar } \\
\text { Cost }\end{array}$ \\
\hline $\begin{array}{r}\text { TOTAL : } \\
\text { RISK FRACTION : }\end{array}$ & $\begin{array}{r}440.1 \\
79.1\end{array}$ & $\begin{array}{l}9.4 \\
0.8\end{array}$ & $\begin{array}{r}122.0 \\
25.0\end{array}$ & $\begin{array}{r}151.5 \\
28.5\end{array}$ \\
\hline $\begin{array}{l}\text { 1. Identify Reservoir } \\
\text { 2. Confirm Reservoir } \\
\text { 3. Prod./Inject. Wells } \\
\text { 4. Downhole Pumps } \\
\text { 5. Gathering Equip. } \\
\text { 6. Make-Up Wells } \\
\text { 7. Power Plant (Core) } \\
\text { 8. Brine TDS Effects } \\
\text { 9. Gas Handling } \\
\text { 0. Reservoir Insurance }\end{array}$ & $\begin{array}{r}9.3 \\
22.4 \\
216.2 \\
4.3 \\
41.1 \\
0.0 \\
127.3 \\
0.1 \\
0.0 \\
19.5\end{array}$ & $\begin{array}{l}0.0 \\
0.0 \\
1.8 \\
0.8 \\
0.8 \\
0.2 \\
5.8 \\
0.0 \\
0.0 \\
0.0\end{array}$ & $\begin{array}{r}2.0 \\
5.3 \\
52.5 \\
1.4 \\
13.7 \\
0.0 \\
40.9 \\
0.0 \\
0.0 \\
6.2\end{array}$ & $\begin{array}{r}2.5 \\
5.3 \\
58.2 \\
4.1 \\
16.3 \\
0.7 \\
58 . \\
0.2 \\
0.3 \\
6.2\end{array}$ \\
\hline
\end{tabular}

IM-GEO: SENSITIVITY FACTORS IN EFFECT O8-02-1990 - 18:47:58

R\&D Achumt: Wildcat Success Ratio

R\&D Achvmt: Confirm. Success Ratio

R\&D Achumt: Testing Costs, Confirm

R\&D Achvmt: Dry Holes / Producer

R\&D Achumt: Testing costs. Producer

R\&D Achvmt: BASE Cost, Average Well

R\&D Achvmt: Cap.cost, Deep Well Pump

R\&D Achvmt: O\&M Cost, Deep Well Pump

R\&D Achumt: Workover Interval. Prod.

R\&D Achvmt: Workover Interval, Injc.

R\&D Achvmt: FLASH Plant - Efficiency

R\&D Achvmt: FLASH Plant - Capital cost

R\&D Achvmt: BINARY Plant - Efficiency

R\&D Achumt: BINARY plant - Capital Cost

$: 1.20$
$: \quad 1.25$
$: 0.75$
$: 0.85$
$: 0.75$
$: 0.80$
$: 0.75$
$: 0.80$
$: 0.50$
$: 0.50$
$: 1.05$
0.95
$: 1.20$
$: 0.76$

Regional Weights = Regional Capacity

(End of Page) 
GEOTHERMAL COST OF POWER ESTIMATE New Techology Costs: B \& R - Vale

RUN: $08-02-1990-18: 47: 58$

\section{[From IMGEO MOdel] \\ ACCOUNT}

TOTAL :
RISK FRACTION :
1. Identify Reservoir
2. Confirm Reservoir
3. Prod./Inject. Wells
4. Downhole Pumps
5. Gathering Equip.
6. Make-UD Wells
7. Power Plant (Core)
8. Brine ToS Effects
9. Gas Handling
10. Reservoir Insurance

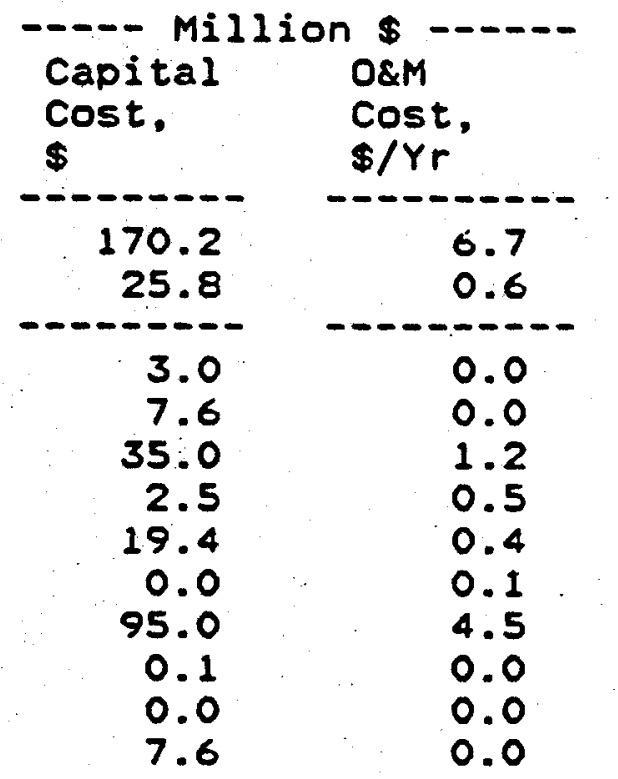

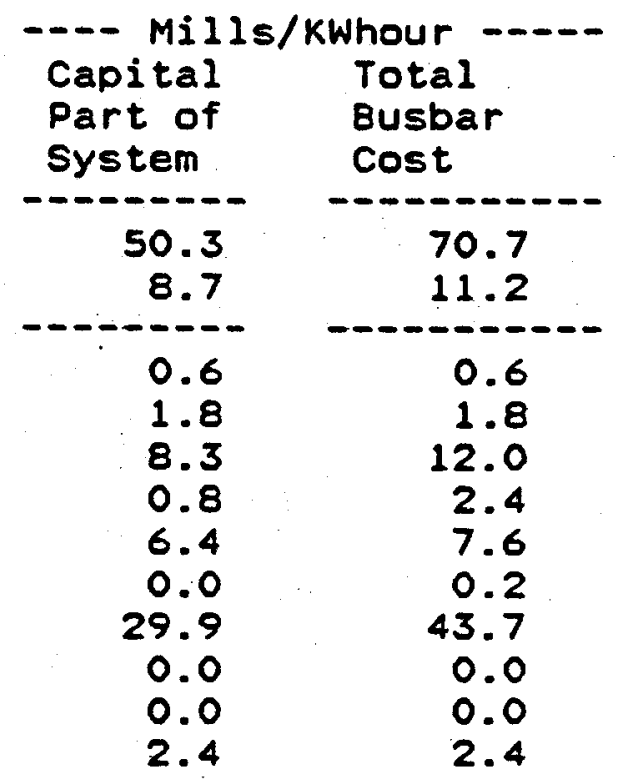

IM-GEO: SENSITIVITY FACTORS IN EFFECT 08-02-1990 - 18:47:58

R\&D Achumt: Wildcat Success Ratio

R\&D Achumt: Confirm. Success Ratio

R\&D Achumt: Testing Costs, Confirm

R\&D Achvmt: Dry Holes / Producer

R\&D Achvmt: Testing Costs, Producer

R\&D Achvmt: BASE Cost, Average well

R\&D Achvmt: Cap.Cost, Deep Well Pump

R\&D Achumt: O\&M Cost, Deep Well Pump

R\&D Achumt: Workover Interval, Prod.

R\&D Achumt: Workover Interval, Injc.

R\&D Achumt: FLASH plant - Efficiency : 1.05

R\&D Achumt: FLASH Plant - Capital cost : 0.95

R\&D AChumt: BINARY Plant - Efficiency : 1.20

R\&D Achumt: BINARY Plant - Capital cost : 0.76

Regional Weights = Regional Capacity

(End of Page)

GEOTHERMAL COST OF POWER ESTIMATE New Techology costs: Y. VOl. - Wilbur HS

RUN: $08-02-1990-18: 47: 58$

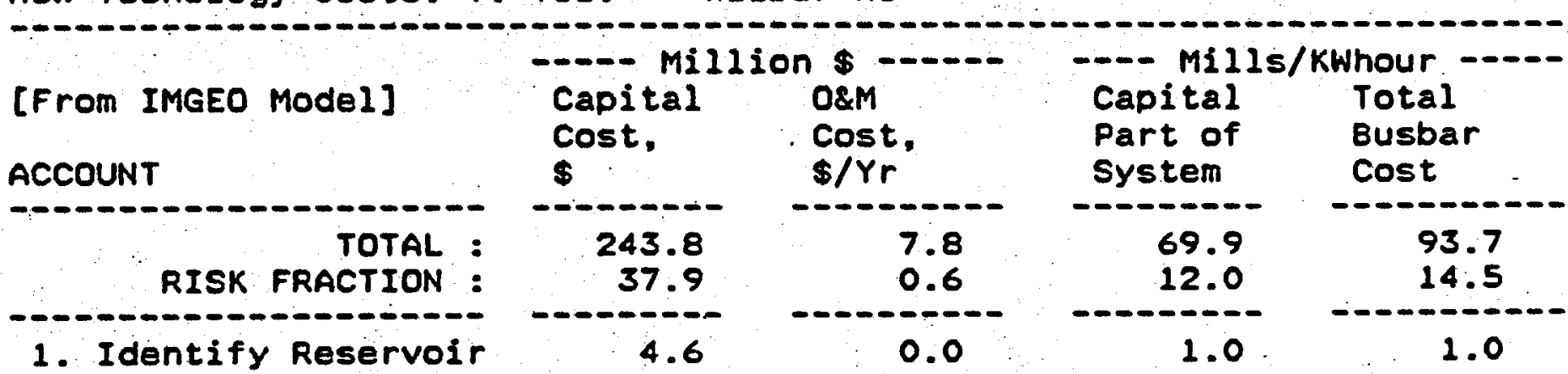


2. Confirm Reservoir

3. Prod./Inject. Wells

4. Downhole Pumps

5. Gathering Equip.

6. Make-Up Wells

7. Power Plant (Core)

8. Brine TDS Effects

9. Gas Handling

10. Reservoir Insurance

$\begin{array}{rr}11.3 & 0.0 \\ 77.4 & 1.4 \\ 3.2 & 0.6 \\ 28.3 & 0.6 \\ 0.0 & 0.1 \\ 108.0 & 5.0 \\ 0.1 & 0.0 \\ 0.0 & 0.0 \\ 10.9 & 0.0\end{array}$

2.6

18.5

1.1

9.2

0.0

34.0

0.0

0.0

3.4
2.6

23.0

3.0

11.0

0.3

49.3

0.0

0.0

\section{IM-GEO: SENSITIVITY FACTORS IN EFFECT 08-02-1990 - 18:47:58}

R\&D Achvmt: Wildcat Success Ratio

R\&D Achvmt: Confirm. Success Ratio

RED Achumt: Testing costs, Confirm

R\&D Achumt: Dry Holes / Producer

R\&D Achumt: Testing Costs, Producer

R\&D Achvmt: BASE Cost, Average Well

R\&D Achumt: Cap.Cost, Deep Well Pump

R\&D Achumt: O\&M Cost, Deep Well Pump

R\&D Achumt: Workover Interval, Prod.

R\&D Achumt: Workover Interval, Inje.

R\&D Achumt: FLASH Plant - Efficiency

R\&D Achumt: FLASH Plant - Capital Cost

R\&D Achumt: BINARY Plant - Efficiency

R\&D Achumt: BINARY Plant - Capital cost

\section{Regional Weights = Regional Capacity}

(End of Page)

$\begin{array}{ll}: & 1.20 \\ : & 1.25 \\ : & 0.75 \\ : & 0.85 \\ : & 0.75 \\ : & 0.80 \\ : & 0.75 \\ : & 0.80 \\ : & 0.50 \\ : & 0.50 \\ : & 1.05 \\ : & 0.95 \\ : & 1.20 \\ : & 0.76\end{array}$

GEOTHERMAL COST OF POWER ESTIMATE New Techology Costs: Y. Vol. - Sespe HS

\begin{tabular}{|c|c|c|c|c|}
\hline $\begin{array}{l}\text { [From IMGEO Model] } \\
\text { ACCOUNT }\end{array}$ & $\begin{array}{l}\text { Capital } \\
\text { Cost. } \\
\$\end{array}$ & $\begin{array}{l}\text { O\&M } \\
\text { Cost } \\
\$ / Y r\end{array}$ & $\begin{array}{l}\text { Capital } \\
\text { Part of } \\
\text { System }\end{array}$ & $\begin{array}{l}\text { Total } \\
\text { Busbar } \\
\text { Cost }\end{array}$ \\
\hline $\begin{array}{r}\text { TOTAL : } \\
\text { RISK FRACTION : }\end{array}$ & $\begin{array}{r}422.0 \\
96.5\end{array}$ & $\begin{array}{r}14.0 \\
2.3\end{array}$ & $\begin{array}{r}128.0 \\
32.7\end{array}$ & $\begin{array}{r}172.5 \\
41.3\end{array}$ \\
\hline $\begin{array}{l}\text { 1. Identify Reservoir } \\
\text { 2. Confirm Reservoir } \\
\text { 3. Prod./Inject. Wells } \\
\text { 4. Downhole Pumps } \\
\text { 5. Gathering Equip. } \\
\text { 6. Make-Up Wells } \\
\text { 7. Power Plant (Core) } \\
\text { 8. Brine TDS Effects } \\
\text { 9. Gas Handling } \\
\text { 10. Reservoir Insurance }\end{array}$ & $\begin{array}{r}2.5 \\
6.4 \\
123.2 \\
8.0 \\
90.4 \\
0.0 \\
171.6 \\
0.2 \\
0.0 \\
19.7\end{array}$ & $\begin{array}{l}0.0 \\
0.0 \\
2.9 \\
1.5 \\
1.8 \\
0.3 \\
7.5 \\
0.0 \\
0.0 \\
0.0\end{array}$ & $\begin{array}{r}0.5 \\
1.5 \\
30.4 \\
2.7 \\
30.5 \\
0.0 \\
55.9 \\
0.1 \\
0.0 \\
6.4\end{array}$ & $\begin{array}{r}0.5 \\
1.5 \\
39.8 \\
7.7 \\
36.4 \\
0.8 \\
79.2 \\
0.1 \\
0.0 \\
6.4\end{array}$ \\
\hline
\end{tabular}




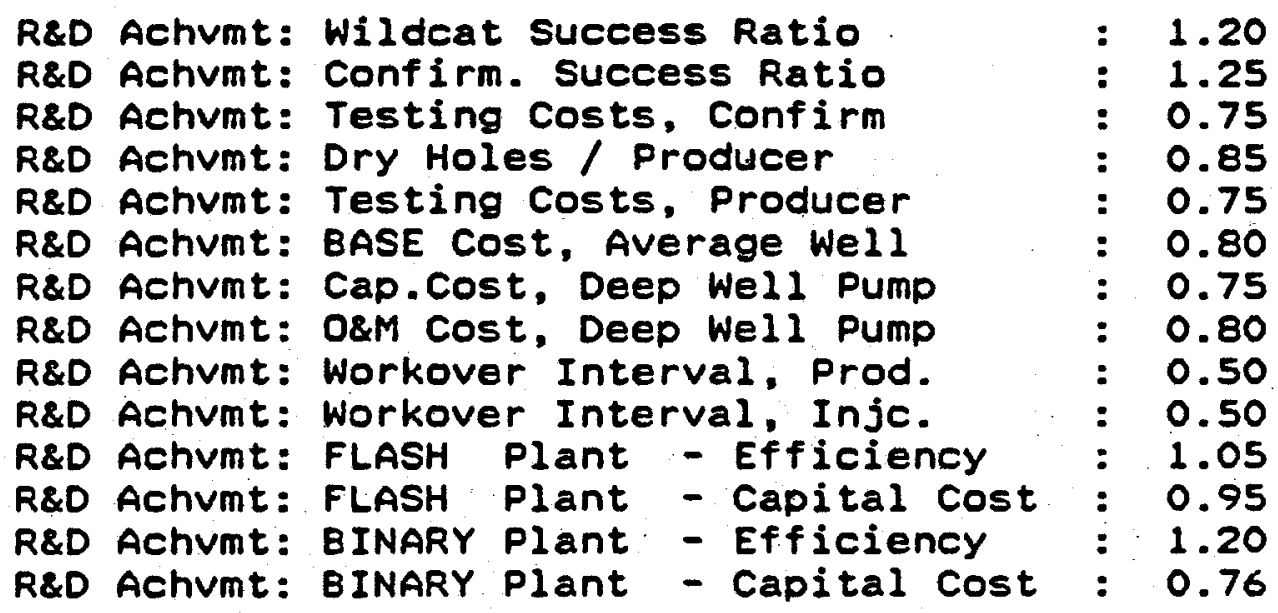

Regional Weights = Regional Capacity

(End of Page) 
GEOTHERMAL COST OF POWER ESTIMATE New Techology Costs: Imperial Valley - Salton

RUN: 08-02-1990-16:43:23

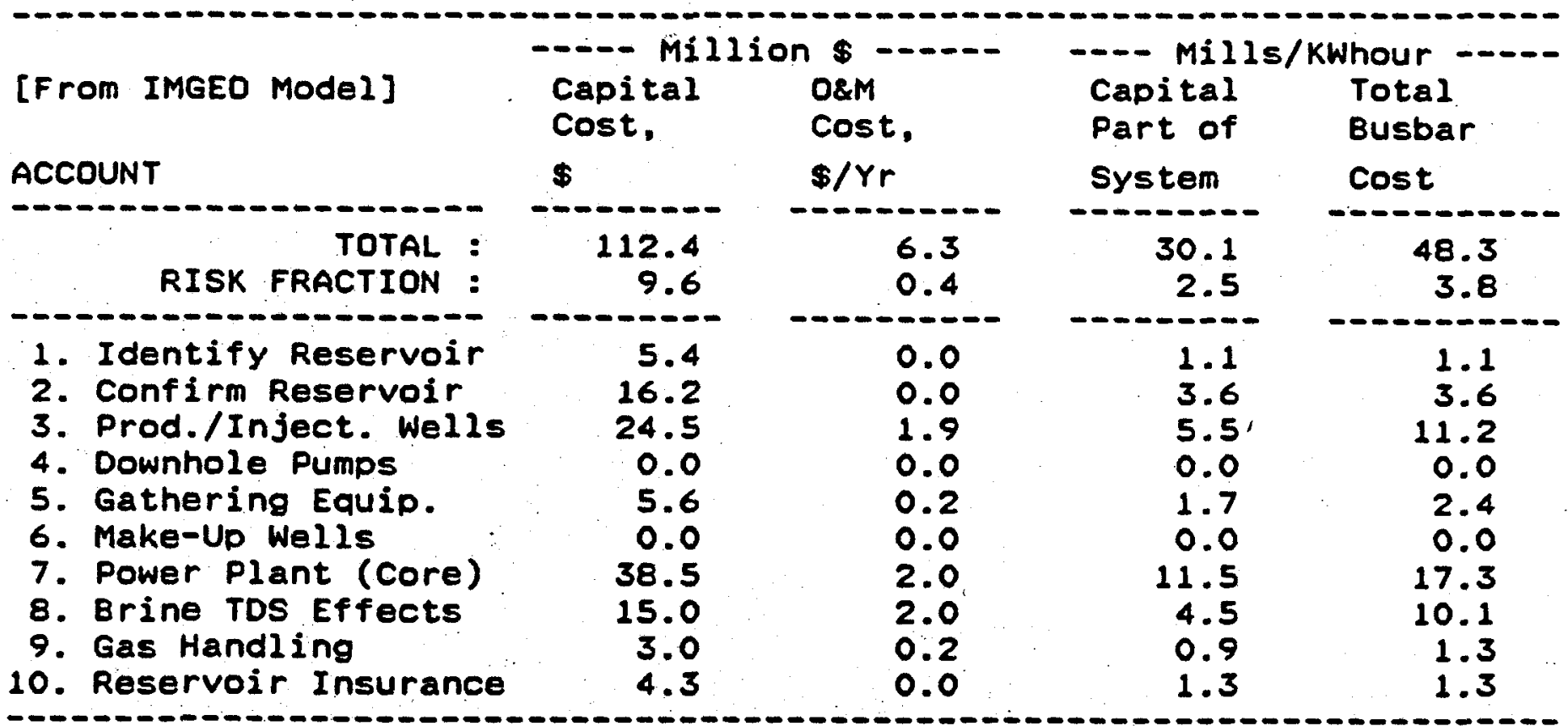

IM-GEO: SENSITIVITY FACTORS IN EFFECT 08-02-1990 - 16:43:23

R\&D Achumt: Wildcat Success Ratio

R\&D Achumt: Confirm. Success Ratio

1.20
$: \quad 0.80$
$: \quad 0.75$
$: 0.85$
$: 0.75$
$: 0.80$
$: 0.75$
$: 0.80$
$: 0.50$
$: 0.50$
$: \quad 1.05$
$: 0.95$
$: \quad 1.20$
$: 0.76$
$: 0.90$
$: 0.80$
$: 0.80$

R\&D Achumt: Testing Costs, Confirm

R\&D Achumt: Dry Holes / Producer

R\&D Achvmt: Testing Costs, Producer

R\&D Achumt: BASE Cost, Average Well

R\&D Achumt: Cap.Cost, Deep Well Pump

R\&D Achvmt: O\&M Cost, Deep Well Pump

R\&D Achvmt: Workover Interval, Prod.

R\&D Achvmt: Workover Interval, Injc.

R\&D Achvmt: FLASH Plant - Efficiency

R\&D Achumt: FLASH Plant - Capital Cost

R\&D Achvmt: BINARY Plant - Efficiency

R\&D Achumt: BINARY Plant - Capital cost

R\&D Achumt: TDS-Clarifier, Capital cost

R\&D Achumt: TDS-Clarifier, O\&M Cost

R\&D Achumt: H2S Treatment, Capital Cost

Regional Weights = Regional Capacity

(End of Page)

GEOTHERMAL COST OF POWER ESTIMATE New Techology Costs: Imperial Valley - Heber

RUN: $08-02-1990-16: 43: 23$

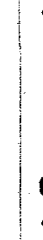

[From IMGEO MOdel]

$\begin{array}{ll} & \text { Million } \$ \\ \text { Capital } & \text { O\&M } \\ \text { Cost, } & \text { Cost, } \\ \$ & \$ / Y r\end{array}$

\begin{tabular}{ll} 
Capital & Total \\
Part of & Busbar \\
System & Cost \\
\hline
\end{tabular}




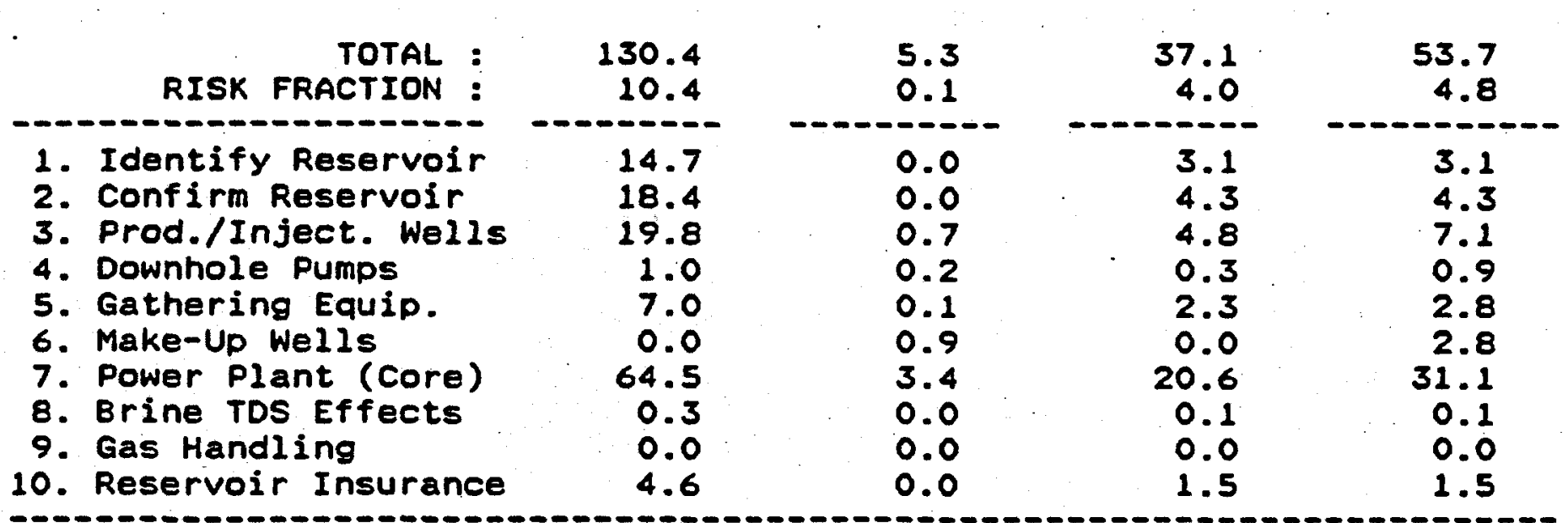

IM-GEO: SENSITIVITY FACTORS IN EFFECT 08-02-1990 - 16:43:23

R\&D Achumt: Wildcat Success Ratio

R\&D Achvmt: Confirm. Success Ratio

R\&D Achumt: Testing Costs, Confirm

R\&D Achvmt: Dry Holes / Producer

R\&D Achvmt: Testing Costs, Producer

R\&D Achvmt: BASE Cost, Average Well

R\&D Achumt: Cap.Cost, Deep Well Pump

R\&D Achvmt: O\&M Cost, Deep Well Pump

R\&D Achvmt: Workover Interval, Prod.

R\&D Achumt: Workover Interval, Inje.

R\&D Achvmt: FLASH Plant - Efficiency : 1.05

R\&D Achumt: FLASH Plant - Capital Cost: 0.95

R\&D Achvmt: BINARY Plant - Efficiency : 1.20

R\&D Achvmt: BINARY Plant - Capital Cost : 0.76

R\&D Achumt: TDS-Clarifier, Capital cost : 0.90

R\&D Achvmt: TDS-Clarifier, 0\&M Cost: : 0.80

R\&D Achvmt: H2S Treatment, Capital cost : 0.80

Regional Weights = Regional Capacity

(End of Page)

GEOTHERMAL COST OF POWER ESTIMATE New Techology Costs: Basin \& Range - Dixie Val

[From IMGEO MOdel]

ACCOUNT

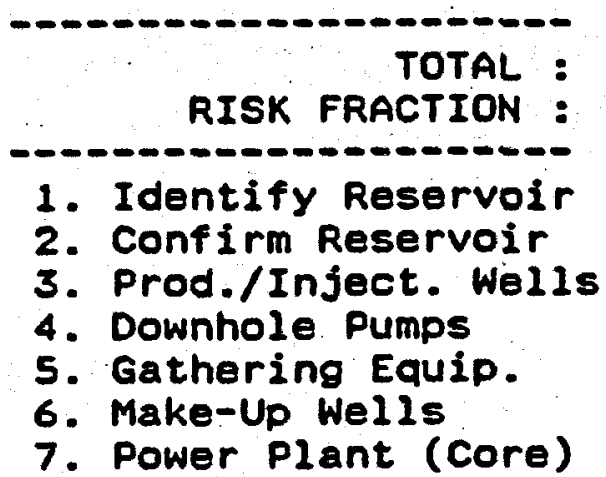

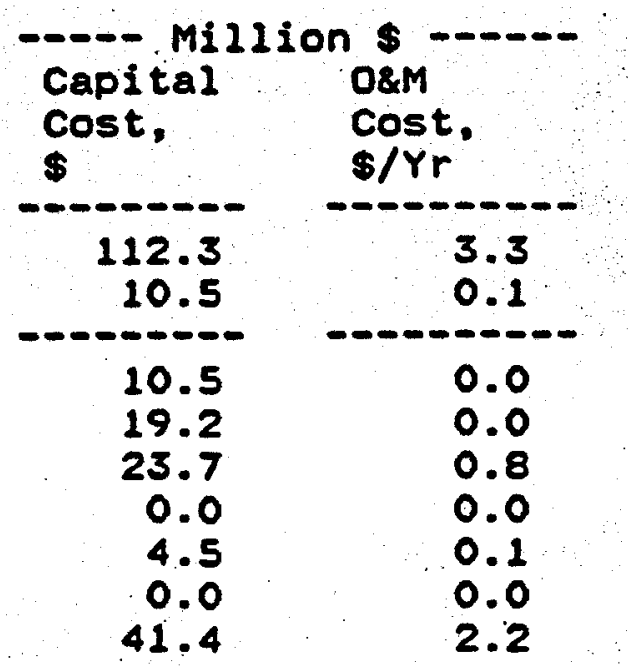

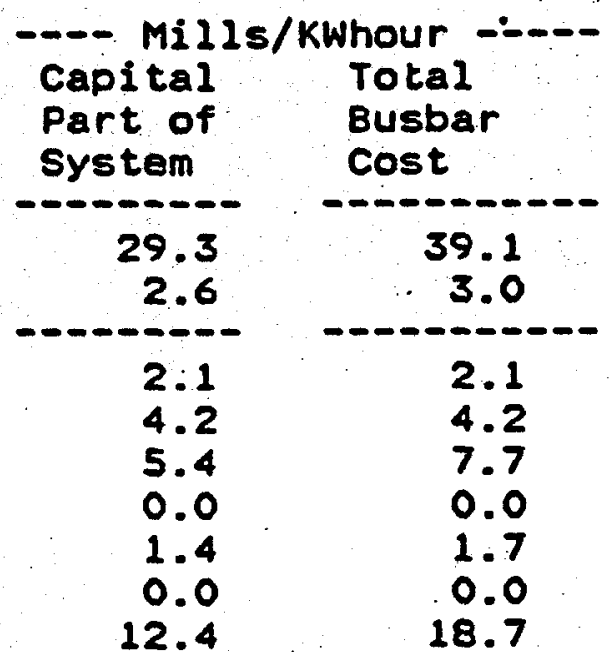


8. Brine TDS Effects

9. Gas Handling

10. Reservoir Insurance
6.5

2.7

3.9
0.2

0.1

0.0
1.9

0.8

1.2

\section{IM-GEO: SENSITIVITY FACTORS IN EFFECT 08-02-1990 - 16:43:23}

R\&D Achvmt: Wildcat Success Ratio

R\&D Achumt: Confirm. Success Ratio

R\&D Achumt: Testing Costs, Confirm

R\&D Achumt: Dry Holes / Producer

R\&D Achvmt: Testing Costs, Producer

R\&D Achumt: BASE Cost, Average Well

R\&D Achumt: Cap.Cost, Deep Well Pump
1.20
0.80
0.75
0.85
0.75
0.80
0.75
0.80
0.50
0.50
1.05
0.95
1.20
0.76
0.90
0.80
0.80

Regional Weights = Regional Capacity

(End of Page)

GEOTHERMAL COST OF POWER ESTIMATE

RUN: $08-02-1990-16: 43: 23$ New Techology Costs: Basin \& Range - Raft R.

\begin{tabular}{|c|c|c|c|c|}
\hline $\begin{array}{l}\text { [From IMGEO Model] } \\
\text { ACCOUNT }\end{array}$ & $\begin{array}{l}\text { Capital } \\
\text { Cost. } \\
\$\end{array}$ & $\begin{array}{l}0 \& M \\
\text { Cost } \\
\$ / Y r\end{array}$ & $\begin{array}{l}\text { Capital } \\
\text { Part of } \\
\text { System }\end{array}$ & $\begin{array}{l}\text { Total } \\
\text { Busbar } \\
\text { Cost }\end{array}$ \\
\hline $\begin{array}{r}\text { TOTAL : } \\
\text { RISK FRACTION : }\end{array}$ & $\begin{array}{r}293.4 \\
40.1\end{array}$ & $\begin{array}{l}8.8 \\
0.8\end{array}$ & $\begin{array}{l}86.2 \\
16.7\end{array}$ & $\begin{array}{r}114.8 \\
21.0\end{array}$ \\
\hline $\begin{array}{l}\text { 1. Identify Reservoir } \\
\text { 2. Confirm Reservoir } \\
\text { 3. Prod./Inject. Wells } \\
\text { 4. Downhole Pumps } \\
\text { 5. Gathering Equip. } \\
\text { 6. Make-Up Wells } \\
\text { 7. Power Plant (Core) } \\
\text { 8. Brine TDS Effects } \\
\text { 9. Gas Handling } \\
\text { 10. Reservoir Insurance }\end{array}$ & $\begin{array}{r}43.3 \\
32.2 \\
57.7 \\
3.3 \\
29.9 \\
0.0 \\
116.1 \\
0.7 \\
0.0 \\
10.4\end{array}$ & $\begin{array}{l}0.0 \\
0.0 \\
1.4 \\
0.6 \\
0.6 \\
0.8 \\
5.3 \\
0.0 \\
0.0 \\
0.0\end{array}$ & $\begin{array}{r}9.6 \\
7.9 \\
14.6 \\
1.2 \\
10.4 \\
0.0 \\
38.8 \\
0.2 \\
0.0 \\
3.5\end{array}$ & $\begin{array}{r}9.6 \\
7.9 \\
19.2 \\
3.3 \\
12.4 \\
2.7 \\
56.0 \\
0.3 \\
0.0 \\
3.5\end{array}$ \\
\hline
\end{tabular}

IM-GEO: SENSITIVITY FACTORS IN EFFECT 08-02-1990 - 16:43:23

R\&D Achumt: Wildcat Success Ratio R\&D Achumt: Confirm. Success Ratio R\&D Achumt: Testing Costs, Confirm
: 1.20

$: 0.80$

0.75 


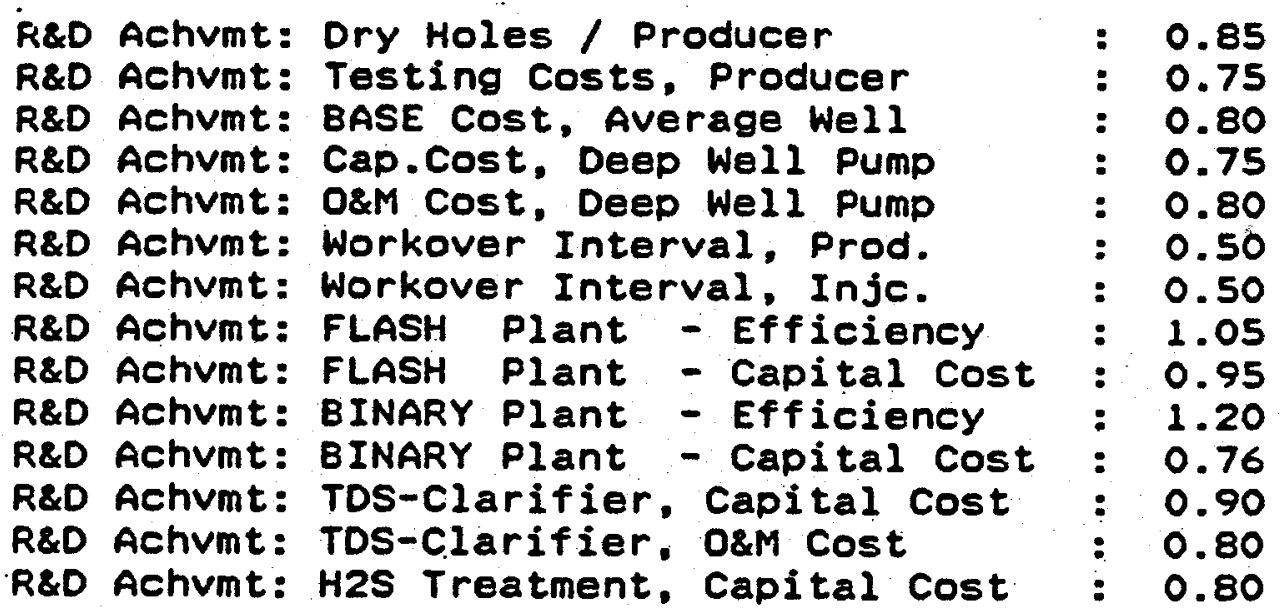

Regional Weights = Regional Capacity

(End of Page)

GEOTHERMAL COST OF POWER ESTIMATE New Techology Costs: Cascades - Lassen

RUN: $08-02-1990-16: 43: 23$

\begin{tabular}{|c|c|c|c|c|}
\hline $\begin{array}{l}\text { [From IMGEO Model] } \\
\text { ACCOUNT }\end{array}$ & $\begin{array}{l}\text { Capital } \\
\text { cost. } \\
\$\end{array}$ & $\begin{array}{l}\text { O\&M } \\
\text { Cost } \\
\$ / Y r\end{array}$ & $\begin{array}{l}\text { Capital } \\
\text { Part of } \\
\text { System }\end{array}$ & $\begin{array}{l}\text { Total } \\
\text { Busbar } \\
\text { Cost }\end{array}$ \\
\hline $\begin{array}{r}\text { TOTAL : } \\
\text { RISK FRACTION : }\end{array}$ & $\begin{array}{r}203.9 \\
22.7\end{array}$ & $\begin{array}{r}3.6 \\
-0.2\end{array}$ & $\begin{array}{r}51.2 \\
6.1\end{array}$ & $\begin{array}{r}61.5 \\
5.7\end{array}$ \\
\hline $\begin{array}{l}\text { 1. Identify Reservoir } \\
\text { 2. Confirm Reservoir } \\
\text { 3. Prod./Inject. Wells } \\
\text { 4. Downhole Pumps } \\
\text { 5. Gathering Equip. } \\
\text { 6. Make-Up Welis } \\
\text { 7. Power Plant (Core) } \\
\text { 8. Brine TDS Effects } \\
\text { 9. Gas Handling } \\
\text { 10. Reservoir Insurance }\end{array}$ & $\begin{array}{l}22.3 \\
33.1 \\
80.7 \\
0.0 \\
9.0 \\
0.0 \\
51.8 \\
0.0 \\
0.0 \\
7.1\end{array}$ & $\begin{array}{l}0.0 \\
0.0 \\
0.6 \\
0.0 \\
0.2 \\
0.3 \\
2.5 \\
0.0 \\
0.0 \\
0.0\end{array}$ & $\begin{array}{r}4.5 \\
7.4 \\
18.6 \\
0.0 \\
2.8 \\
0.0 \\
15.7 \\
0.0 \\
0.0 \\
2.2\end{array}$ & $\begin{array}{r}4.5 \\
7.5 \\
20.4 \\
0.5 \\
3.1 \\
0.5 \\
23.1 \\
0.1 \\
0.1 \\
2.8\end{array}$ \\
\hline
\end{tabular}

IM-GEO: SENSITIVITY FACTORS IN EFFECT 08-02-1990 - 16:43:23

R\&D Achvmt: Wildcat success Ratio

R\&D Achvmt: Confirm. Success Ratio

R\&D Achumt: Testing Costs, Confirm

R\&D Achumt: Dry Holes / Producer

R\&D Achvmt: Testing costs, Producer

R\&D Achivmt: BASE Cost, Average Well

R\&D Achumt: Cap.Cost, Deep Well Pump

R\&D Achvmt: O\&M Cost, Deep Well Pump

R\&D Achvmt: Workover Interval. Prod.

R\&D Achumt: Workover Interval. Injc.

R\&D Achumt: FLASH Plant - Efficiericy

R\&D AChvmt: FLASH Plant - Capital cost

R\&D Achvmt: BINARY Plant - Efficiency:

$\begin{array}{ll}: & 1.20 \\ : & 0.80 \\ : & 0.75 \\ : & 0.85 \\ : & 0.75 \\ : & 0.80 \\ : & 0.75 \\ : & 0.80 \\ : & 0.50 \\ : & 0.50 \\ : & 1.05 \\ : & 0.95 \\ : & 1.20\end{array}$


R\&D Achumt: BINARY Plant - Capital cost : 0.76
R\&D AChumt: TDS-Clarifier, Capital Cost : 0.90
R\&D AChumt: TDS-Clarifier, O\&M Cost $: 0.80$
R\&D AChumt: H2S Treatment, Capital Cost : 0.80

Regional Weights = Regional Capacity

(End of Page)

GEOTHERMAL COST OF POWER ESTIMATE

RUN: $08-02-1990-16: 43: 23$

New Techology Costs: Cascades - Alvord Desert

\begin{tabular}{|c|c|c|c|c|}
\hline $\begin{array}{l}\text { [From IMGEO Model] } \\
\text { ACCOUNT }\end{array}$ & $\begin{array}{l}\text { Capital } \\
\text { Cost, } \\
\$\end{array}$ & $\begin{array}{l}\$ \$ \\
\text { o\&M } \\
\text { Cost } \\
\$ / Y r\end{array}$ & $\begin{array}{l}-- \text { Mil } \\
\text { Capital } \\
\text { Part of } \\
\text { System }\end{array}$ & $\begin{array}{l}\text { Whour } \\
\text { Total } \\
\text { Busbar } \\
\text { Cost }\end{array}$ \\
\hline $\begin{array}{r}\text { TOTAL : } \\
\text { RISK FRACTION : }\end{array}$ & $\begin{array}{r}167.9 \\
14.9\end{array}$ & $\begin{array}{l}4.8 \\
0.4\end{array}$ & $\begin{array}{r}44.0 \\
4.7\end{array}$ & $\begin{array}{r}58.3 \\
6.0\end{array}$ \\
\hline $\begin{array}{l}\text { 1. Identify Reservoir } \\
\text { 2. Confirm Reservoir } \\
\text { 3. Prod./Inject. Wells } \\
\text { 4. Downhole Pumps } \\
\text { 5. Gathering Equip. } \\
\text { 6. Make-Up Wells } \\
\text { 7. Power Plant (Core) } \\
\text { 8. Brine TOS Effects } \\
\text { 9. Gas Handling } \\
\text { 10. Reservoir Insurance }\end{array}$ & $\begin{array}{r}34.9 \\
27.6 \\
20.9 \\
1.5 \\
9.6 \\
0.0 \\
68.3 \\
0.0 \\
0.0 \\
5.0\end{array}$ & $\begin{array}{l}0.0 \\
0.0 \\
0.8 \\
0.3 \\
0.2 \\
0.0 \\
3.5 \\
0.0 \\
0.0 \\
0.0\end{array}$ & $\begin{array}{r}7.1 \\
6.2 \\
4.8 \\
0.5 \\
3.0 \\
0.0 \\
20.9 \\
0.0 \\
0.0 \\
1.5\end{array}$ & $\begin{array}{l}7.1 \\
6.2 \\
7.3 \\
1.4 \\
3.6 \\
0.0 \\
31.3 \\
0.0 \\
0.0 \\
1.5\end{array}$ \\
\hline
\end{tabular}

IM-GEO: SENSITIVITY FACTORS IN EFFECT $08-02-1990-16: 43: 23$

R\&D Achvmt: Wildcat Success Ratio

R\&D Achvmt: Confirm. Success Ratio

R\&D Achumt: Testing Costs, Confirm

R\&D Achvmt: : Dry Holes / Producer

R\&D Achvmt: Testing Costs, Producer

R\&D Achumt: BASE Cost, Average Well

R\&D Achvmt: Cap.Cost. Deep Well Pump

R\&D Achumt: O\&M Cost, Deep Well Pump

R\&D Achvmt: Workover Interval, Prod.

R\&D Achvmt: Workover Interval, Injc.

R\&D Achumt: FLASH Plant - Efficiency

R\&D Achumt: FLASH Plant - Capital cost

R\&D Achvmt: BINARY Plant - Efficiency

R\&D Achumt: BINARY Plant - Capital cost

R\&D Achumt: TDS-Clarifier. Capital Cost

R\&D Achvmt: TDS-Clarifier, O\&M Cost

R\&D Achumt: H2S Treatment, Capital Cost: 0.80

1.20
0.80
0.75
0.85
0.75
0.80
0.75
0.80
0.50
0.50
1.05
0.95
1.20
0.76
0.90
0.80
0.80

Regional Weights = Regional Capacity

(End of Page) 
GEOTHERMAL COST OF POWER ESTIMATE New Techology Costs: Young Volcanics - Coso

\begin{tabular}{|c|c|c|c|c|}
\hline $\begin{array}{l}\text { [From IMGEO Model] } \\
\text { ACCOUNT }\end{array}$ & $\begin{array}{l}\text { Capital } \\
\text { Cost } \\
\$\end{array}$ & $\begin{array}{l}\text { o\&M } \\
\text { Cost } \\
\$ / Y r\end{array}$ & $\begin{array}{l}\text { Capital } \\
\text { Part of } \\
\text { System }\end{array}$ & $\begin{array}{l}\text { Total } \\
\text { Busbar } \\
\text { Cost }\end{array}$ \\
\hline $\begin{array}{r}\text { TOTAL : } \\
\text { RISK FRACTION : }\end{array}$ & $\begin{array}{r}102.8 \\
5.7\end{array}$ & $\begin{array}{l}7.0 \\
0.2\end{array}$ & $\begin{array}{r}28.0 \\
1.5\end{array}$ & $\begin{array}{r}48 . \\
2 .\end{array}$ \\
\hline $\begin{array}{l}\text { 1. Identify Reservoir } \\
\text { 2. Confirm Reservoir } \\
\text { 3. Prod./Inject. Wells } \\
\text { 4. Downhole Pumps } \\
\text { 5. Gathering Equip. } \\
\text { 6. Make-Up Welis } \\
\text { 7. Power Plant (Core) } \\
\text { 8. Brine Tos Effects } \\
\text { 9. Gas Handling } \\
\text { 10. Reservoir Insurance }\end{array}$ & $\begin{array}{r}6.0 \\
14.6 \\
15.0 \\
0.0 \\
4.5 \\
0.0 \\
40.6 \\
15.5 \\
2.7 \\
3.9\end{array}$ & $\begin{array}{l}0.0 \\
0.0 \\
1.6 \\
0.0 \\
0.2 \\
0.1 \\
2.1 \\
2.9 \\
0.2 \\
0.0\end{array}$ & $\begin{array}{r}1.2 \\
3.2 \\
3.4 \\
0.0 \\
1.4 \\
0.0 \\
12.2 \\
4.7 \\
0.8 \\
1.2\end{array}$ & $\begin{array}{r}1.2 \\
3.2 \\
8.1 \\
0.5 \\
1.5 \\
0.3 \\
18.3 \\
12.5 \\
1.3 \\
1.2\end{array}$ \\
\hline
\end{tabular}

IM-GEO: SENSITIVITY FACTORS IN EFFECT 08-02-1990 - 16:43:23

R\&D Achvmt: Wildcat Success Ratio

R\&D Achumt: Confirm. Success Ratio

R\&D Achumt: Testing Costs, Confirm

R\&D Achumt: Dry Holes / Producer

RED Achvmt: Testing Costs, Producer

R\&D Achumt: BASE Cost, Average Well

R\&D Achumt: Cap.Cost, Deep Well Pump

R\&D Achumt: O\&M Cost, Deep Well Pump

R\&D Achvmt: Workover Interval, Prod.

R\&D Achumt: Workover Interval. Inje.

R\&D Achumt: FLASH Plant - Efficiency

RUN: $08-02-1990-16: 43: 23$

R\&D AChvmt:

R\&D Achumt:

R\&D Achumt:

FLASH plant - Capital cost

BINARY Plant - Efficiency

RED Achumt: TDS-Clarifier Capital cost

R\&D Achumt: TDS-clariffer. O\&M Cost : 0.80

R\&D Achumt: H2S Treatment, Capital cost: 0.80

Regional Weights = Regional Capacity

(End of Page)

GEOTHERMAL COST OF POWER ESTIMATE RUN: 08-02-1990 - 16:43:23 New Techology Costs: Young Vol. - Long Valley 


\begin{tabular}{cc}
$\$$ & $\$ / Y r$ \\
\hline 108.4 & 4.5 \\
8.9 & 0.3 \\
\hline 7.7 & 0.0 \\
10.0 & 0.0 \\
13.4 & 0.7 \\
0.9 & 0.2 \\
8.7 & 0.2 \\
0.0 & 0.0 \\
63.4 & 3.3 \\
0.1 & 0.0 \\
0.0 & 0.0 \\
4.3 & 0.0
\end{tabular}

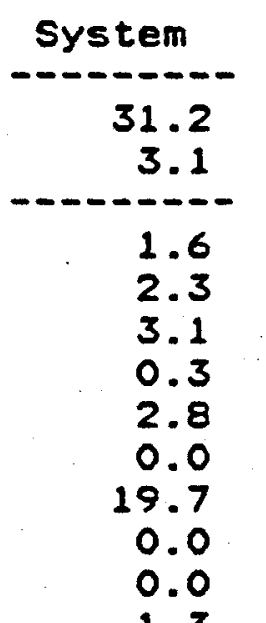

Cost

RISK FRACTION :
1. Identify Reservoir
2. Confirm Reservoir
3. Prod./Inject. Welis
4. Downhole Pumps
5. Gathering Equip.
6. Make-Up Wells
7. Power Plant (Core)
8. Brine TDS Effects
9. Gas Handling
10. Reservoir Insurance

4.3

1.3

44.7

4.1

1.6

2.3

5.4

1.0

3.4

0.0

29.7

0.0

0.0

1.3

\section{IM-GEO: SENSITIVITY FACTORS IN EFFECT O8-02-1990 - 16:43:23}

R\&D Achvmt: Wildcat Success Ratio

R\&D Achvmt: Confirm. Success Ratio

R\&D Achumt: Testing Costs, Confirm

R\&D Achumt: Dry Holes / Producer

R\&D Achumt: Testing Costs, Producer

R\&D Achumt: BASE Cost, Average Well

R\&D Achumt: Cap.cost, Deep Well Pump

R\&D Achvmt: O\&M Cost, Deep Well Pump

R\&D Achumt: Workover Interval, Prod.

R\&D Achumt: Workover Interval. Inje.

R\&D Achumt: FLASH Plant - Efficiency

R\&D Achumt: FLASH Plant - Capital Cost

R\&D Achumt: BINARY Plant - Efficiency

R\&D Achumt: BINARY Plant - Capital cost

R\&D AChumt: TDS-Clarifier, Capital cost

R\&D Achvmt: TDS-Clarifier, O\&M Cost

R\&D Achumt: H2S Treatment, Capital cost

$: 1.20$
$: \quad 0.80$
$: 0.75$
$: 0.85$
$: 0.75$
$: 0.80$
$: 0.75$
$: 0.80$
$: 0.50$
$: \quad 1.05$
$: 0.95$
$: \quad 1.20$
$: 0.76$
$: 0.90$
$: 0.80$
$: \quad 0.80$

Regional Weights = Regional Capacity

(End of Page)

R\&D Achumt: Wildcat Success Ratio

R\&D Achvmt: Confirm. Success Ratio

R\&D Achumt: Testing costs, Confirm

R\&D Achvmt: Dry Holes / Producer

R\&D Achvmt: Testing Costs, Producer

R\&D Achvmt: BASE cost, Average Well

R\&D Achumt: Cap.cost, Deep Well Pump

R\&D Achumt: O\&M Cost, Deep Well Pump

R\&D Achumt: Workover Interval, Prod.

R\&D Achvmt: Workover Interval, Injc.

R\&D Achumt: FLASH plant - Efficiency

R\&D Achumt: FLASH Plant - Capital Cost

R\&D AChumt: BINARY Plant - Efficiency

R\&D Achumt: BINARY Plant - Capital cost

1.20
$: 0.80$
$: 0.75$
$: 0.85$
$: 0.75$
$: 0.80$
$: 0.75$
$: 0.80$
$: 0.50$
$: \quad 1.05$
$: \quad 1.95$
$: 0.76$


RED Achumt: TDS-Clarifier, Capital cost

R\&D Achumt: TDS-Clarifier, O\&M Cost

R\&D Achumt: H2S Treatment, Capital cost
0.90

0.80

0.80

Regional Weights = Regional Capacity

(End of Page) 
A REPORT FROM THE IM-GEO PROGRAM

GEOTHERMAL COST OF POWER ESTIMATE

RUN : 08-08-1990-11:45:11 NEW TECHNOLOGY COSTS:

SITE = Deep fractures - Paradise

[From IM-GEO 3.05]

ACCOUNT

RISK FRACTION :
1. Identify Reservoir
2. Confirm Reservoir
3. Prod./Inject. Wells
4. Downhole Pumps
5. Gathering Equip.
6. Make-Up Welis
7. Power Plant (Core)
8. Brine TDS Effects
9. Gas Handling

\begin{tabular}{|c|c|}
\hline $\begin{array}{l}\text { CAP. } \\
\$ M\end{array}$ & $\begin{array}{l}\text { O\&M } \\
\$ M / Y R .\end{array}$ \\
\hline $\begin{array}{r}283.3 \\
24.7\end{array}$ & $\begin{array}{l}9.9 \\
0.9\end{array}$ \\
\hline $\begin{array}{r}20.6 \\
17.7 \\
87.1 \\
2.9 \\
25.3 \\
0.0 \\
117.4 \\
0.7 \\
0.0\end{array}$ & $\begin{array}{l}0.0 \\
0.0 \\
1.6 \\
0.6 \\
0.5 \\
3.4 \\
3.9 \\
0.0 \\
0.0\end{array}$ \\
\hline
\end{tabular}

\begin{tabular}{l} 
CAP. \\
PART \\
\hline 7.89 \\
0.84 \\
-0.43 \\
0.41 \\
2.07 \\
0.10 \\
0.82 \\
0.00 \\
3.68 \\
0.02 \\
0.00
\end{tabular}

Cents

O\&M

PART

---D

3.05

0.33

$----$

0.00

0.00

0.49

0.18

0.16

1.05

1.18

0.00

0.00

0.00
KWhour

TOTAL TOTAL

COST

\% CHG

- - - - - - -

$10.95-29.8$

$1.17-37.3$

$-.-.-.-.-1$

$0.43 \quad-43.6$

$0.41-36.7$

$2.56-36.6$

$0.27-39.2$

$0.98 \quad-27.8$

$1.05-33.1$

$4.86 \quad-22.0$

$0.02 \quad-6.7$

$0.00 \quad-7.6$

$0.37-30.4$

10. Reservoir Insurance

11.7

0.37

.PA (End of Page)

A REPORT FROM THE IM-GEO PROGRAM

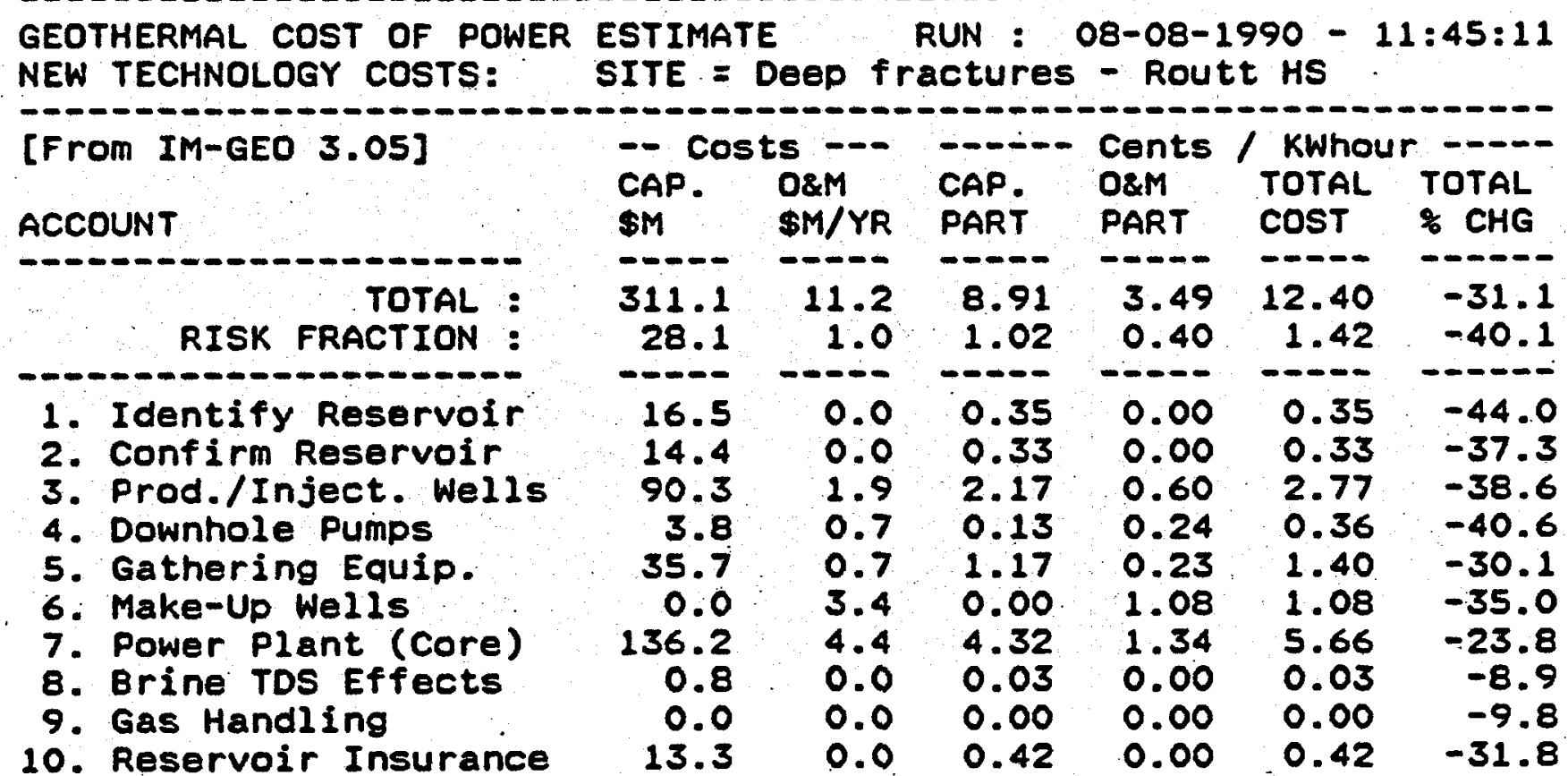


A REPORT FROM THE IM-GEO PROGRAM

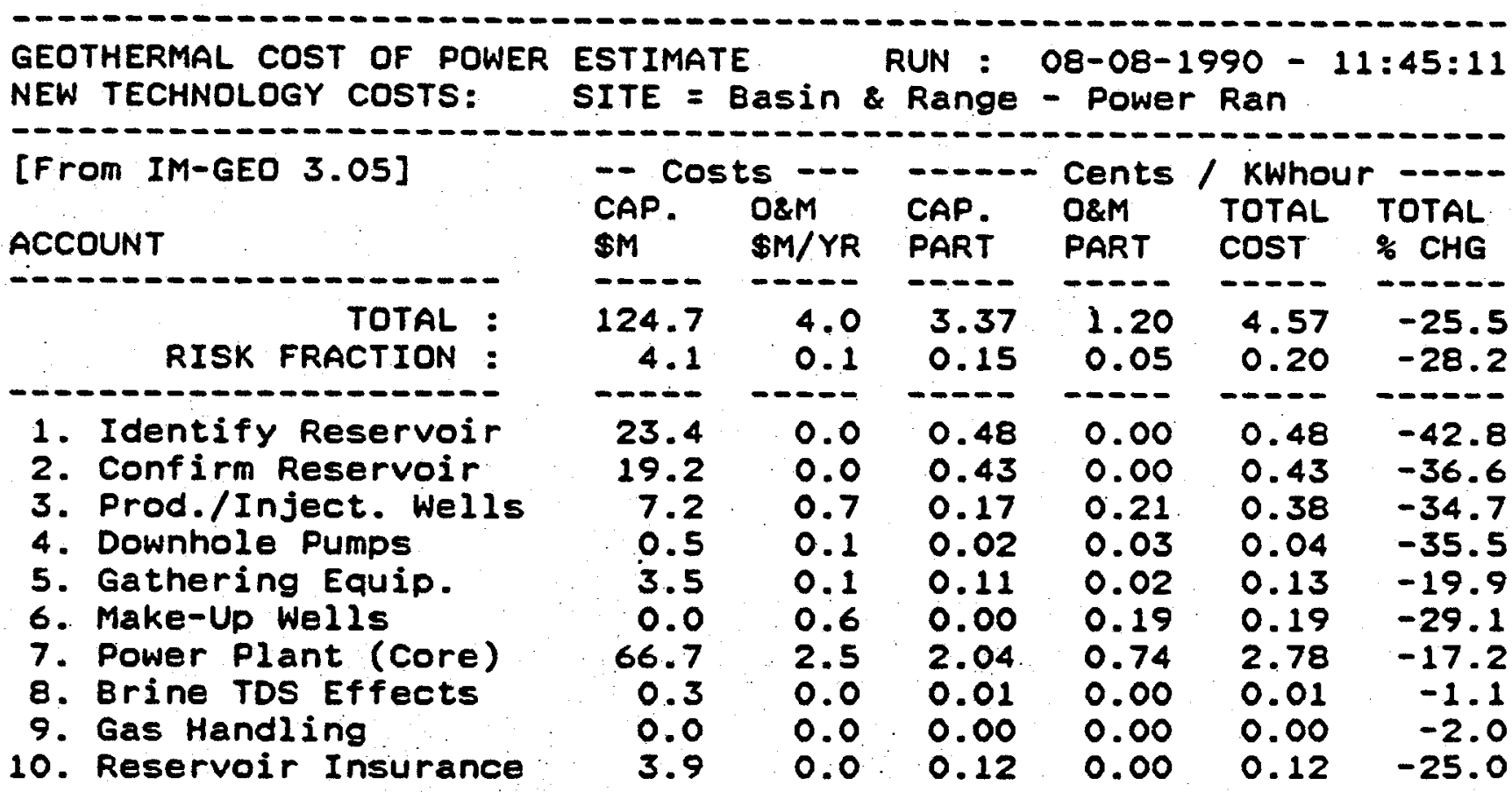

.PA (End of Page)

A REPORT FROM THE IM-GEO PROGRAM

\begin{tabular}{|c|c|c|c|c|c|c|}
\hline $\begin{array}{l}\text { OTHERMAL COST OF POWER } \\
\text { W TECHNOLOGY COSTS: }\end{array}$ & SITE: & $0 G$ & 8 & 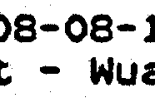 & ta & \\
\hline rom IM-GEO 3.05] & $\begin{array}{l}-\overline{C O} \\
\mathrm{CAP}_{S M}\end{array}$ & $\begin{array}{l}\text { LS } \\
\text { O\&M } \\
\$ M / Y R\end{array}$ & $\begin{array}{l}\text { CAP } \\
\text { PART }\end{array}$ & $\begin{array}{l}\text { Cents } \\
\text { O\&M } \\
\text { PART }\end{array}$ & $\begin{array}{l}\text { KWhou } \\
\text { TOTAL } \\
\text { COST }\end{array}$ & $\begin{array}{l}\text { TOTAL } \\
8 \mathrm{CHG}\end{array}$ \\
\hline $\begin{array}{r}\text { TOTAL : } \\
\text { RISK FRACTION : }\end{array}$ & & $\begin{array}{l}6.9 \\
0.4\end{array}$ & $\begin{array}{l}5.43 \\
0.44\end{array}$ & 2. & & $\begin{array}{l}-26 \\
-34\end{array}$ \\
\hline $\begin{array}{l}\text { 1. Identify Reservoir } \\
\text { 2. Confirm Reservoir } \\
\text { 3. Prod./ Inject. Wells } \\
\text { 4. Downhole Pumps } \\
\text { 5. Gathering Equip. } \\
\text { 6. Make-Up Wells } \\
\text { 7. Power Plant (Core) } \\
\text { 8. Brine TDS Effects } \\
\text { 9. Gas Handling } \\
\text { 1. Reservoir Insurance }\end{array}$ & $\begin{array}{r}11.6 \\
9.6 \\
31.3 \\
2.1 \\
17.5 \\
0.0 \\
106.6 \\
0.6 \\
0.0 \\
7.9\end{array}$ & $\begin{array}{l}0.0 \\
0.0 \\
1.3 \\
0.4 \\
0.3 \\
1.3 \\
3.6 \\
0.0 \\
0.0 \\
0.0\end{array}$ & $\begin{array}{l}0.24 \\
0.22 \\
0.74 \\
0.07 \\
0.57 \\
0.00 \\
3.32 \\
0.02 \\
0.00 \\
0.25\end{array}$ & $\begin{array}{l}0.00 \\
0.00 \\
0.39 \\
0.13 \\
0.11 \\
0.39 \\
1.08 \\
0.00 \\
0.00 \\
0.00\end{array}$ & $\begin{array}{l}0.24 \\
0.22 \\
1.13 \\
0.20 \\
0.67 \\
0.39 \\
4.41 \\
0.02 \\
0.00 \\
0.25\end{array}$ & $\begin{array}{r}-41.9 \\
-37.7 \\
-35.8 \\
-38.0 \\
-25.4 \\
-31.9 \\
-20.4 \\
-4.9 \\
-5.8 \\
-27.3\end{array}$ \\
\hline
\end{tabular}


A REPORT FROM THE IM-GEO PROGRAM

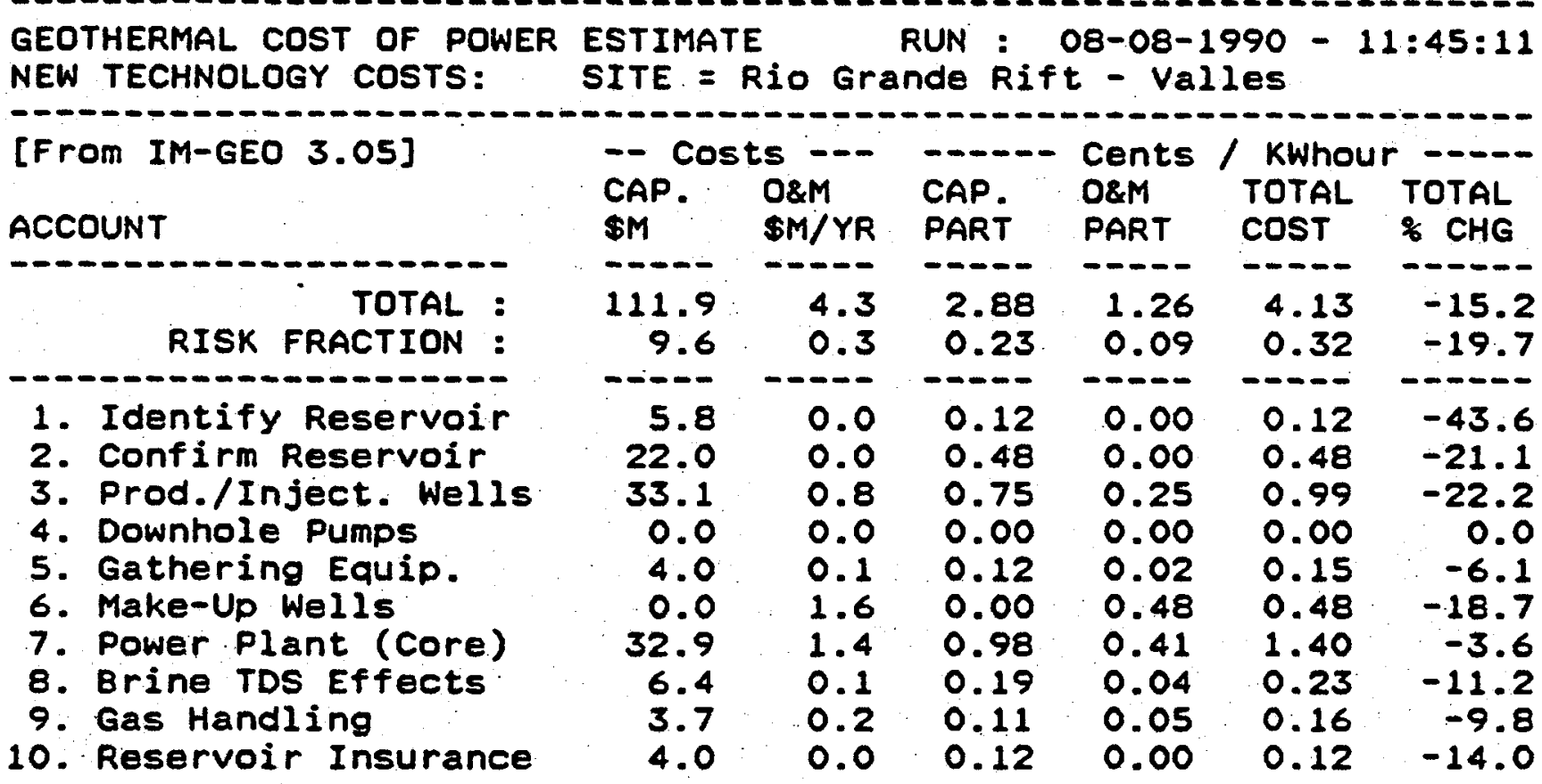

.PA (End of Page)

A REPORT FROM THE IM-GEO PROGRAM

GEOTHERMAL COST OF POWER ESTIMATE RUN : 08-08-1990 - 11:45:11 NEW TECHNOLOGY COSTS: SITE = RIO Grande Rift - LOWEr

\begin{tabular}{|c|c|c|c|c|c|c|}
\hline $\begin{array}{l}\text { [From IM-GEO } 3.05] \\
\text { ACCOUNT }\end{array}$ & $\begin{array}{l}-C O \\
\text { CAP. } \\
S M\end{array}$ & $\begin{array}{l}\text { S\&M } \\
\text { SM/YR }\end{array}$ & PART & $\begin{array}{l}\text { Cents } \\
\text { O\&M } \\
\text { PART }\end{array}$ & $\begin{array}{l}\text { KWhOL } \\
\text { TOTAL } \\
\text { COST }\end{array}$ & $\begin{array}{l}\text { TOTAL } \\
\% \text { CHG }\end{array}$ \\
\hline $\begin{array}{r}\text { TOTAL : } \\
\text { RISK FRACTION : }\end{array}$ & $\begin{array}{r}371.8 \\
40.7\end{array}$ & $\begin{array}{r}13.9 \\
1.5\end{array}$ & $\begin{array}{r}11.09 \\
1.55\end{array}$ & $\begin{array}{l}4.43 \\
0.62\end{array}$ & $\begin{array}{r}15.51 \\
2.17\end{array}$ & $\begin{array}{l}-34.3 \\
-45.3\end{array}$ \\
\hline $\begin{array}{l}\text { 1. Identify Reservoir } \\
\text { 2. Confirm Reservoir } \\
\text { 3. Prod. / Inject. Wells } \\
\text { 4. Downhole Pumps } \\
\text { 5. Gathering Equip. } \\
\text { 6. Make-Up Wells } \\
\text { 7. Power Plant (Core) } \\
\text { 8. Brine TDS Effects } \\
\text { 9. Gas Handling } \\
\text { 10. Reservoir Insurance }\end{array}$ & $\begin{array}{r}12.6 \\
10.3 \\
97.8 \\
5.6 \\
58.7 \\
0.0 \\
169.3 \\
1.0 \\
0.0 \\
16.6\end{array}$ & $\begin{array}{l}0.0 \\
0.0 \\
2.8 \\
1.1 \\
1.2 \\
3.6 \\
5.3 \\
0.0 \\
0.0 \\
0.0\end{array}$ & $\begin{array}{l}0.27 \\
0.24 \\
2.39 \\
0.19 \\
1.96 \\
0.00 \\
5.46 \\
0.03 \\
0.00 \\
0.54\end{array}$ & $\begin{array}{l}0.00 \\
0.00 \\
0.89 \\
0.35 \\
0.38 \\
1.16 \\
1.65 \\
0.00 \\
0.00 \\
0.00\end{array}$ & $\begin{array}{l}0.27 \\
0.24 \\
3.28 \\
0.54 \\
2.34 \\
1.16 \\
7.11 \\
0.04 \\
0.00 \\
0.54\end{array}$ & $\begin{array}{l}-42.3 \\
-38.4 \\
-42.2 \\
-43.5 \\
-34.7 \\
-37.8 \\
-27.4 \\
-13.2 \\
-14.0 \\
-34.9\end{array}$ \\
\hline
\end{tabular}


A REPORT FROM THE IM-GEO PROGRAM

\begin{tabular}{|c|c|c|c|c|c|c|}
\hline $\begin{array}{l}\text { EOTHERMAL COST OF POWER } \\
\text { EW TECHNOLOGY COSTS: }\end{array}$ & $\begin{array}{l}\text { ESTIMA } \\
\text { SITE = }\end{array}$ & & $\begin{array}{l}\text { RUN : } \\
\text { lolcanic }\end{array}$ & $S-P$ & & \\
\hline $\begin{array}{l}\text { From IM-GEO } 3.05] \\
\text { CCOUNT }\end{array}$ & $\begin{array}{l}--\operatorname{COS} \\
\text { CAP. } \\
\text { SM }\end{array}$ & $\begin{array}{l}S=- \\
\text { S\&M } \\
\text { SM/YR }\end{array}$ & PAP. & $\begin{array}{l}\text { Cents } \\
\text { D\&M } \\
\text { PART }\end{array}$ & $\begin{array}{l}\text { KWhol } \\
\text { TOTAL } \\
\text { COST }\end{array}$ & $\begin{array}{l}\text { TOTAL } \\
\% \text { CHG }\end{array}$ \\
\hline $\begin{array}{r}\text { TOTAL : } \\
\text { RISK FRACTION : }\end{array}$ & $\begin{array}{r}113.0 \\
7.1\end{array}$ & $\begin{array}{l}7.2 \\
0.5\end{array}$ & $\begin{array}{l}2.94 \\
0.18\end{array}$ & $\begin{array}{l}2.13 \\
0.15\end{array}$ & $\begin{array}{l}5.07 \\
0.33\end{array}$ & $\begin{array}{l}--- \\
-2\end{array}$ \\
\hline $\begin{array}{l}\text { 1. Identify Reservoir } \\
\text { 2. Confirm Reservoir } \\
\text { 3. Prod./Inject. Wells } \\
\text { 4. Downhole Pumps } \\
\text { 5. Gathering Equip. } \\
\text { 6. Make-Up Wells } \\
\text { 7. Power Plant (Core) } \\
\text { 8. Brine TDs Effects } \\
\text { 9. Gas Handling } \\
\text { 10. Reservoir Insurance }\end{array}$ & $\begin{array}{r}5.3 \\
11.6 \\
43.2 \\
0.0 \\
9.5 \\
0.0 \\
28.8 \\
6.4 \\
3.6 \\
4.6\end{array}$ & $\begin{array}{l}0.0 \\
0.0 \\
3.4 \\
0.0 \\
0.2 \\
1.9 \\
1.3 \\
0.2 \\
0.2 \\
0.0\end{array}$ & $\begin{array}{l}0.11 \\
0.26 \\
0.98 \\
0.00 \\
0.30 \\
0.00 \\
0.86 \\
0.19 \\
0.11 \\
0.14\end{array}$ & $\begin{array}{l}0.00 \\
0.00 \\
1.02 \\
0.00 \\
0.06 \\
0.56 \\
0.39 \\
0.06 \\
0.05 \\
0.00\end{array}$ & $\begin{array}{l}0.11 \\
0.26 \\
2.00 \\
0.00 \\
0.35 \\
0.56 \\
1.25 \\
0.26 \\
0.16 \\
0.14\end{array}$ & $\begin{array}{r}-42 \\
-25 \\
-27 \\
0 \\
-6 \\
-17 \\
-3 \\
-10 \\
-9 \\
-13\end{array}$ \\
\hline
\end{tabular}

.PA (End of Page)

A REPORT FROM THE IM-GEO PROGRAM

GEOTHERMAL COST OF POWER ESTIMATE RUN : 08-08-1990 - 11:45:11 NEW TECHNOLOGY COSTS: SITE = YOung VOlCaniCS - SW Rift

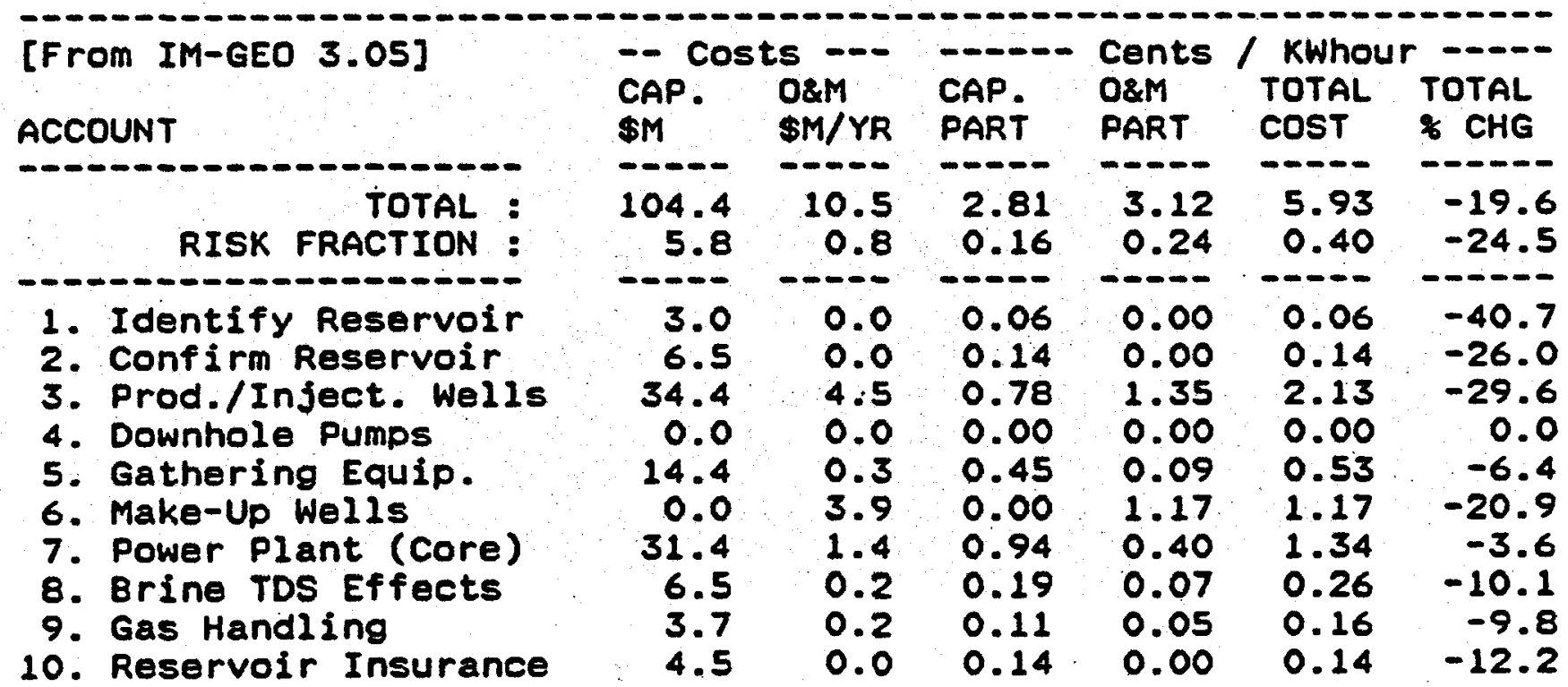


APPENDIX C 


\section{SUPPLY OF GEOTHERMAL POWER AT COST}

Regions 6, 8-10 current technology, identified resources only.

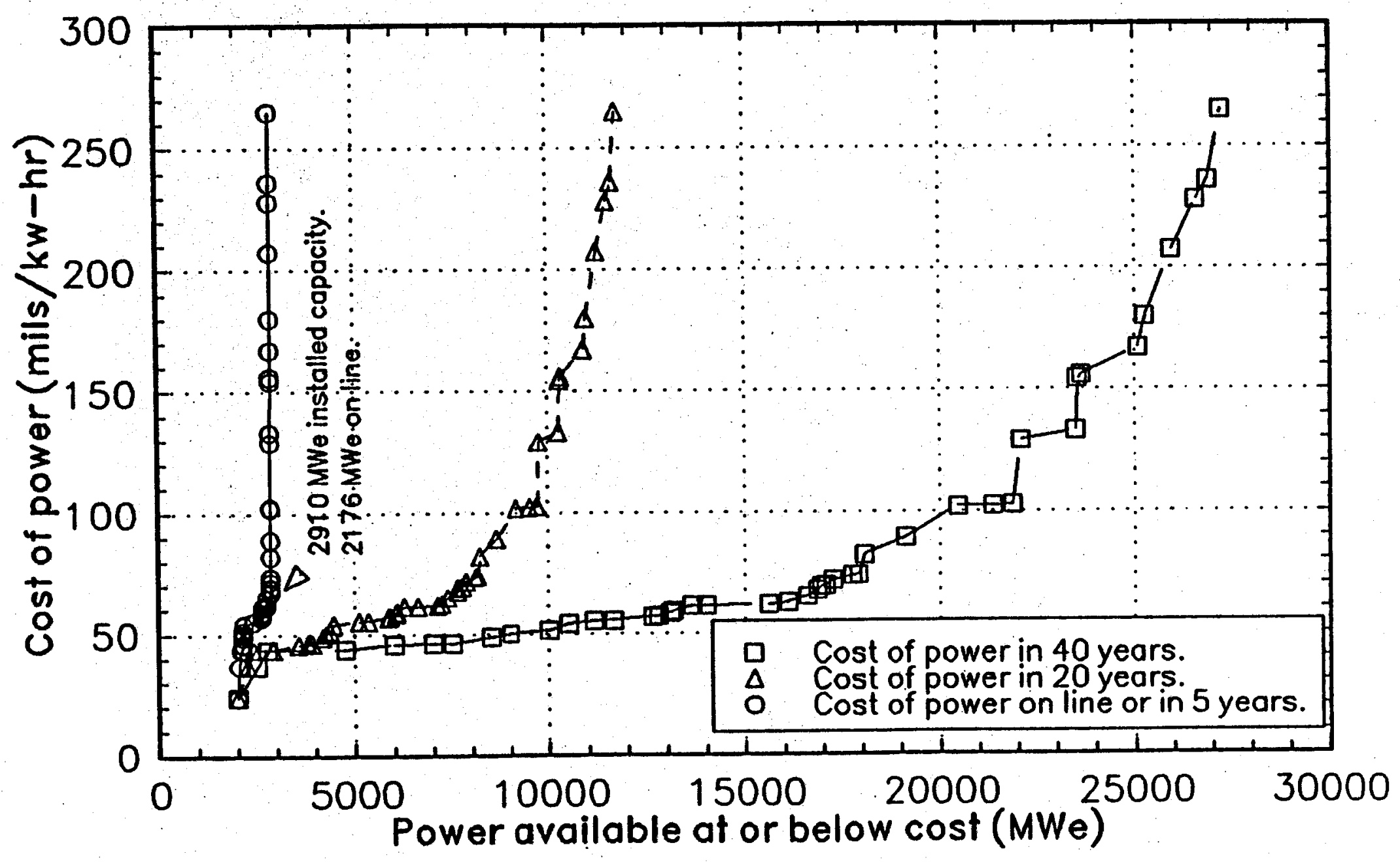




\section{SUPPLY OF GEOTHERMAL POWER AT COST}

Power in Region 6 at current rate of technology change.

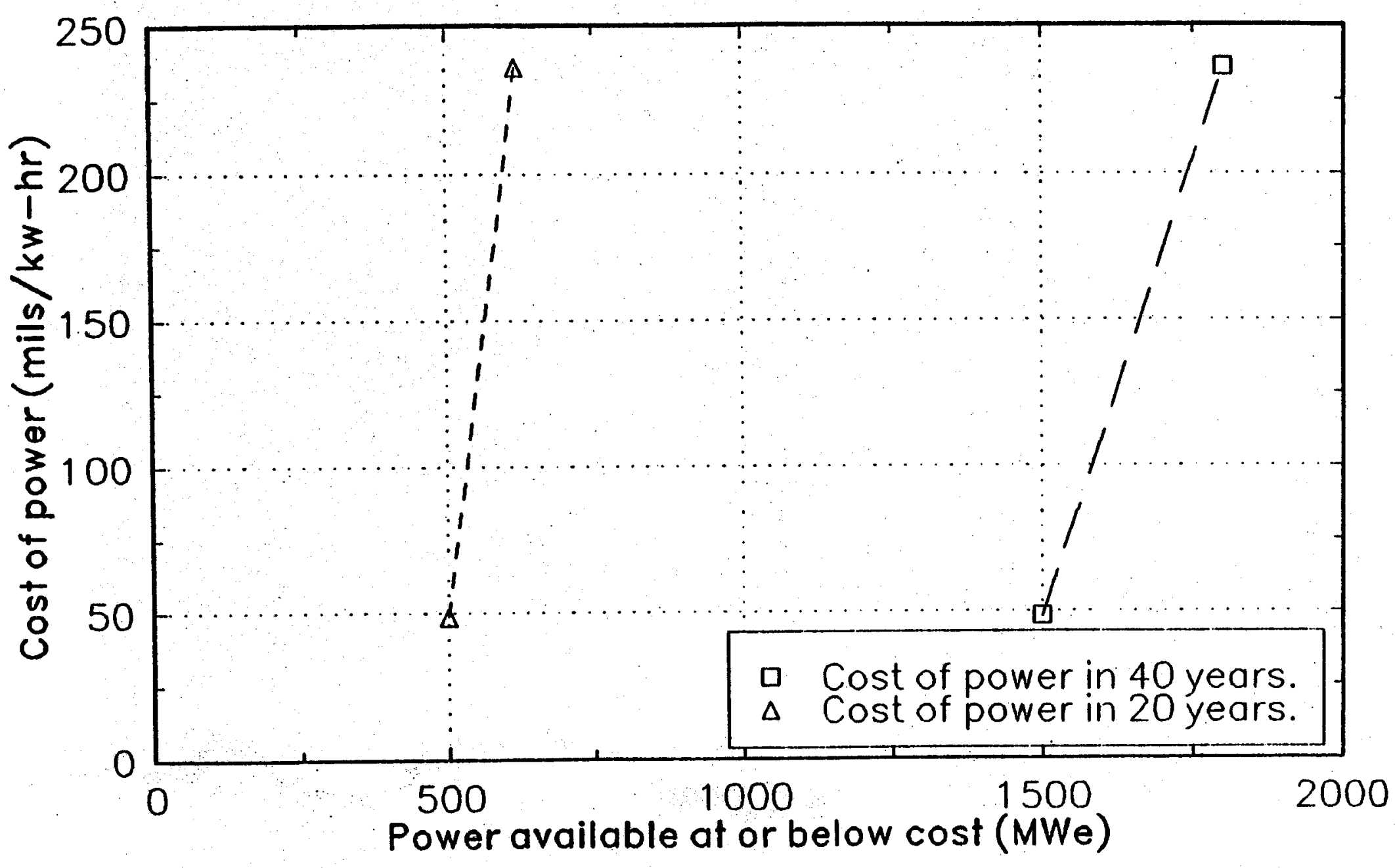


SUPPLY OF GEOTHERMAL POWER AT COST

Power in Region 8 at current rate of technology change.

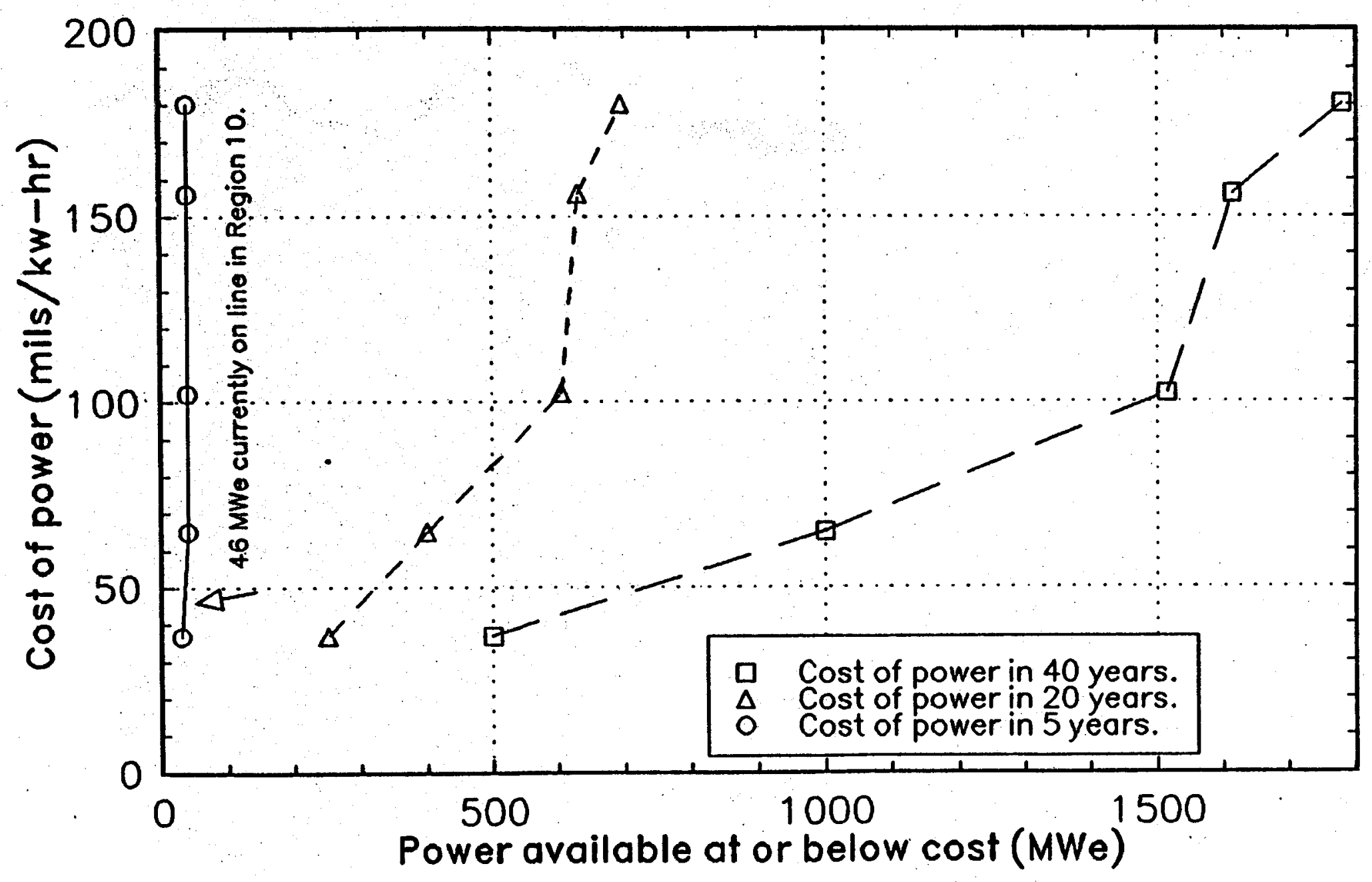


SUPPLY OF GEOTHERMAL POWER AT COST

Power in Region 9 at current rate of technology change.

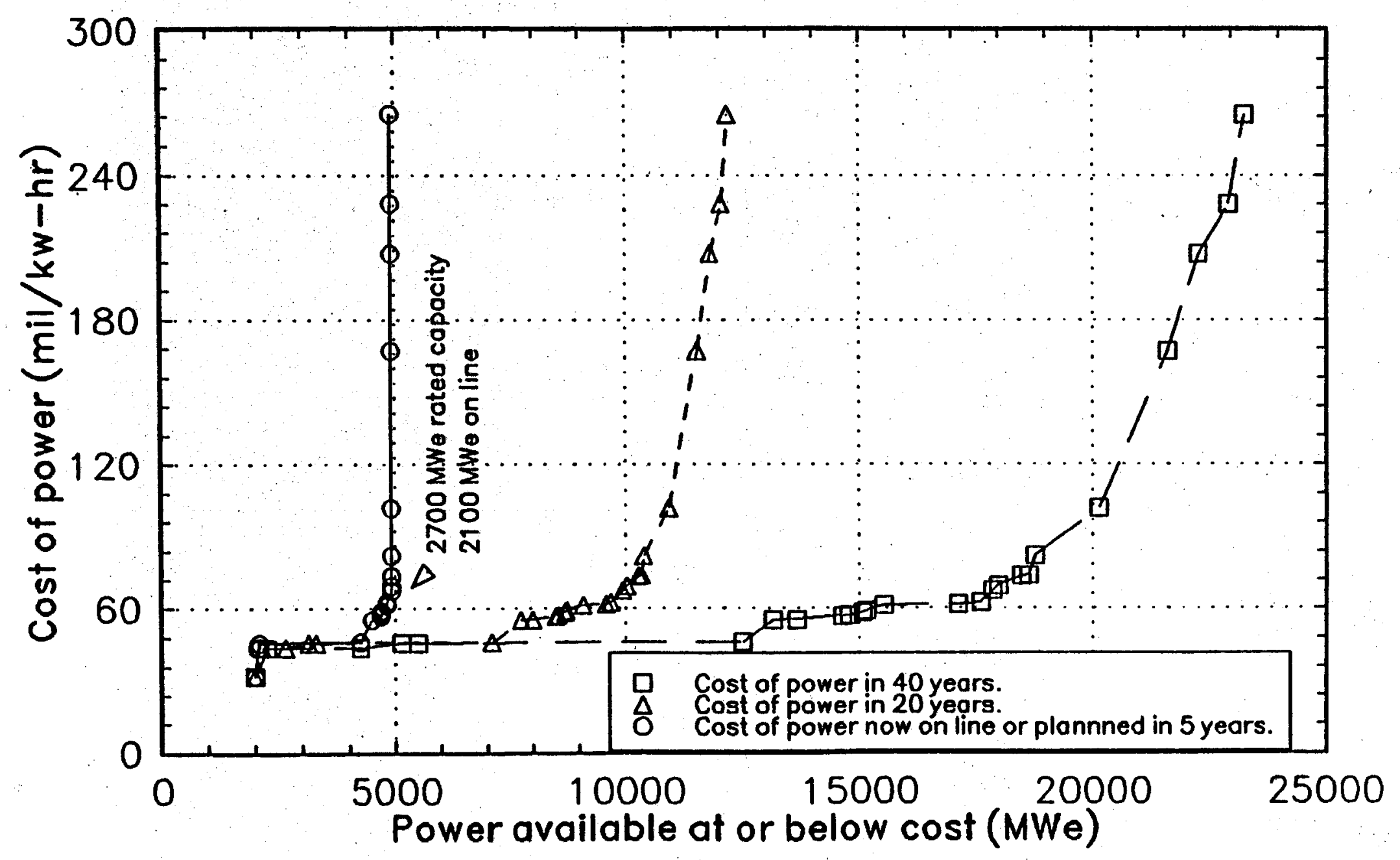


SUPPLY OF GEOTHERMAL POWER AT COST

Power in Region 10 at current rate of technology change.

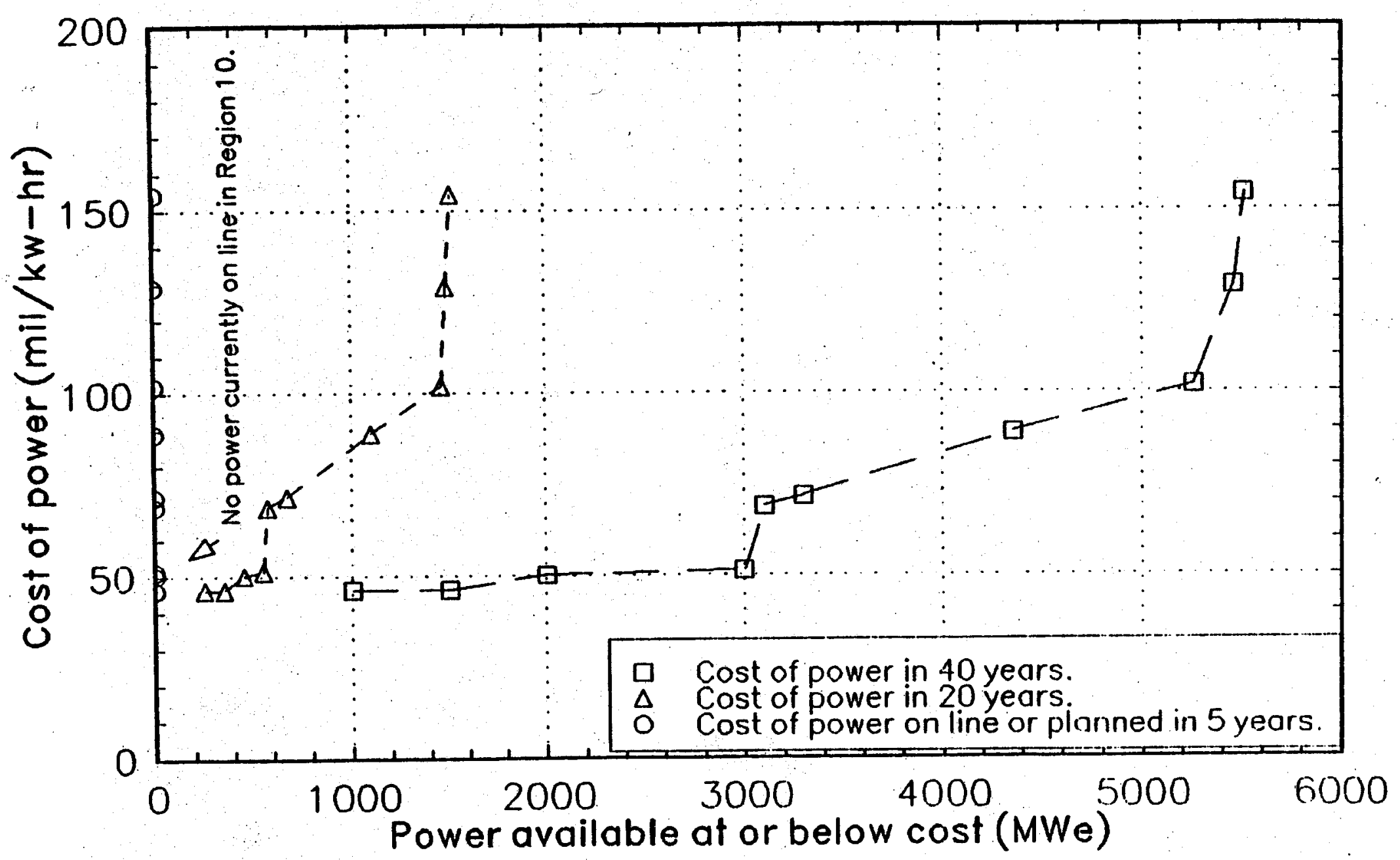




\section{SUPPLY OF GEOTHERMAL POWER AT COST}

Regions 6, 8-10, current technology, unidentified resources included.

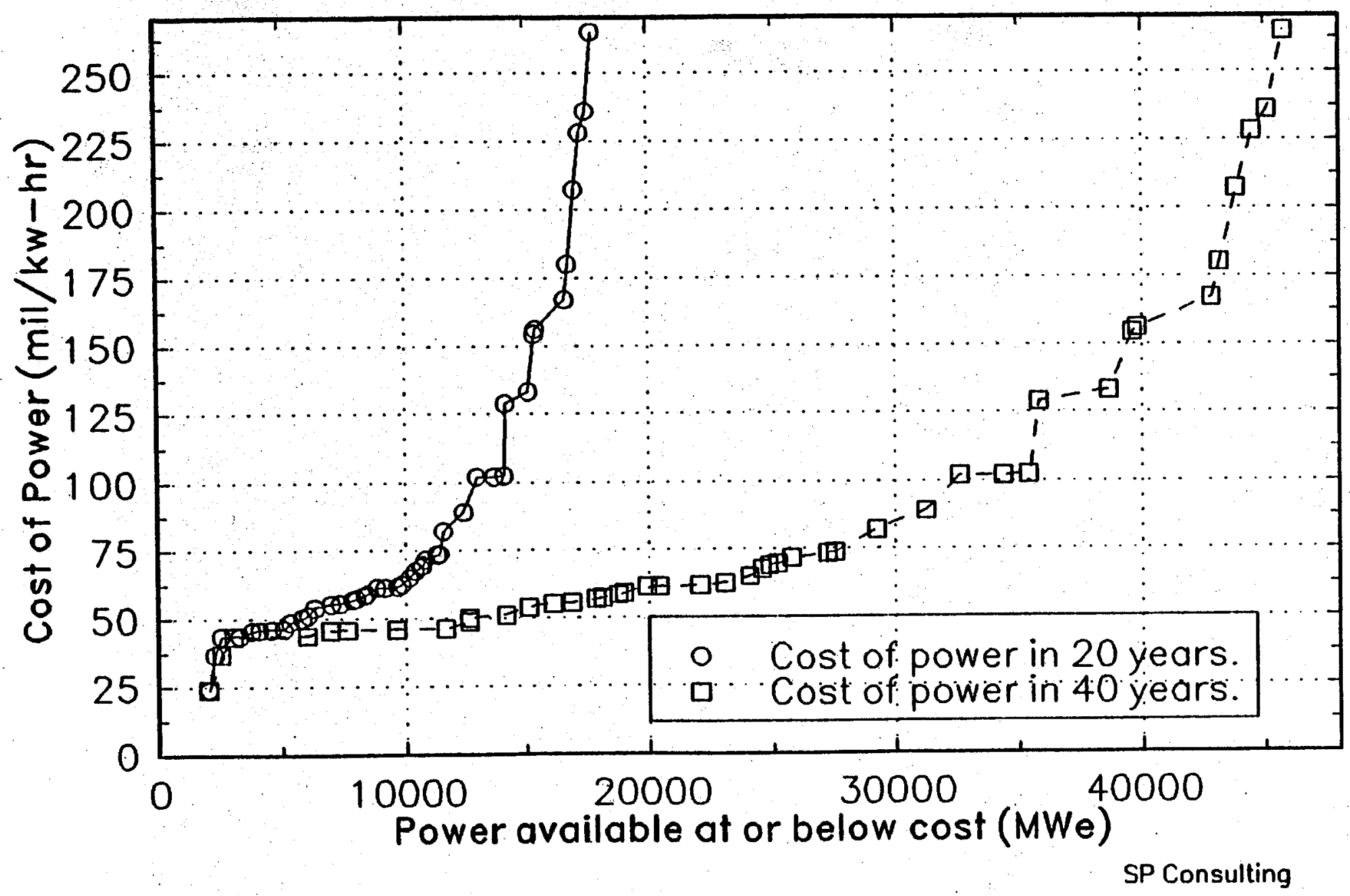


SUPPLY OF GEOTHERMAL POWER AT COST

Regions 6, 8-10, increased technology, identified resources only.

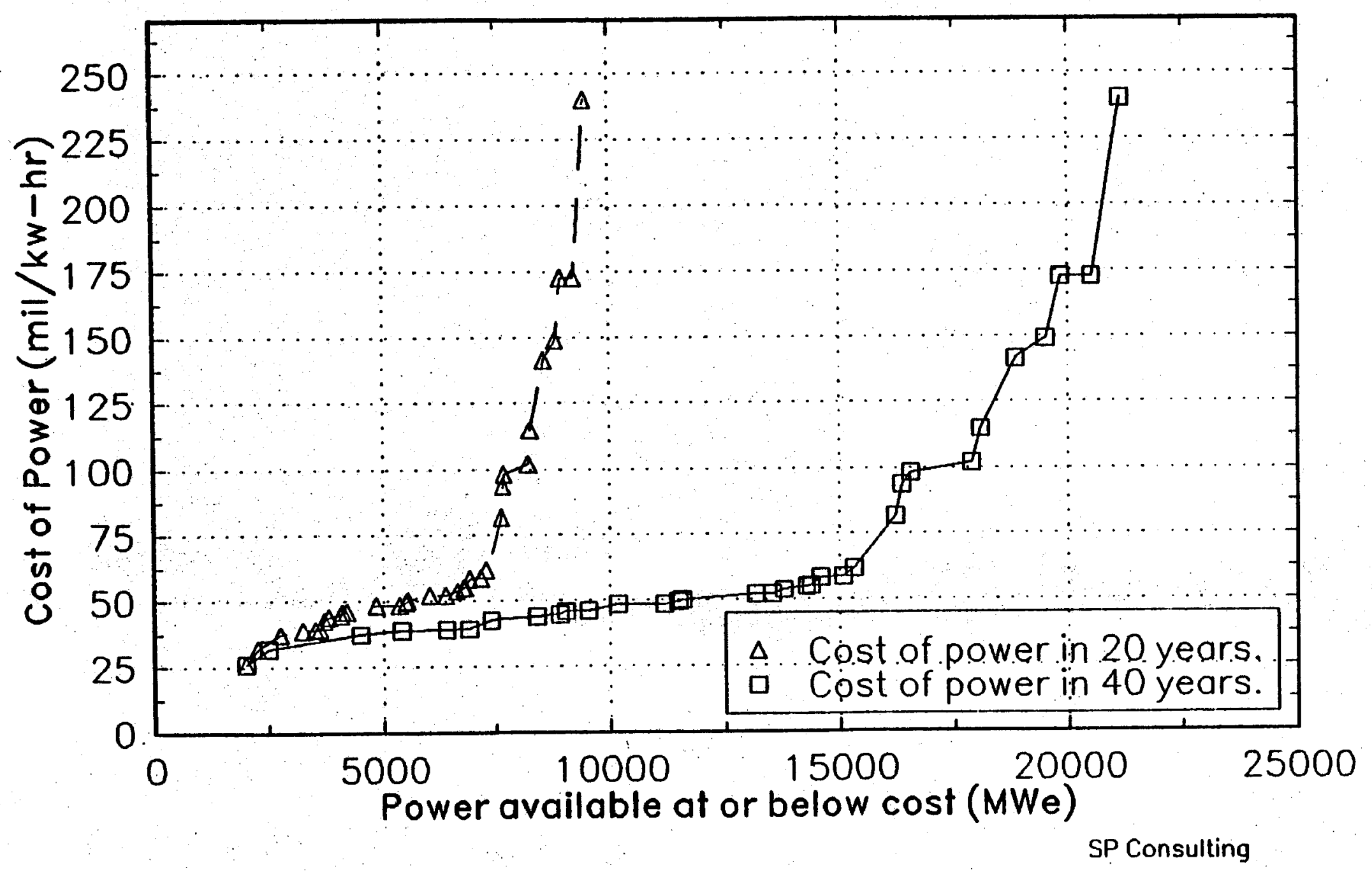




\section{SUPPLY OF GEOTHERMAL POWER AT COST}

Regions 6, 8-10, increased technology, unidentified resources included.

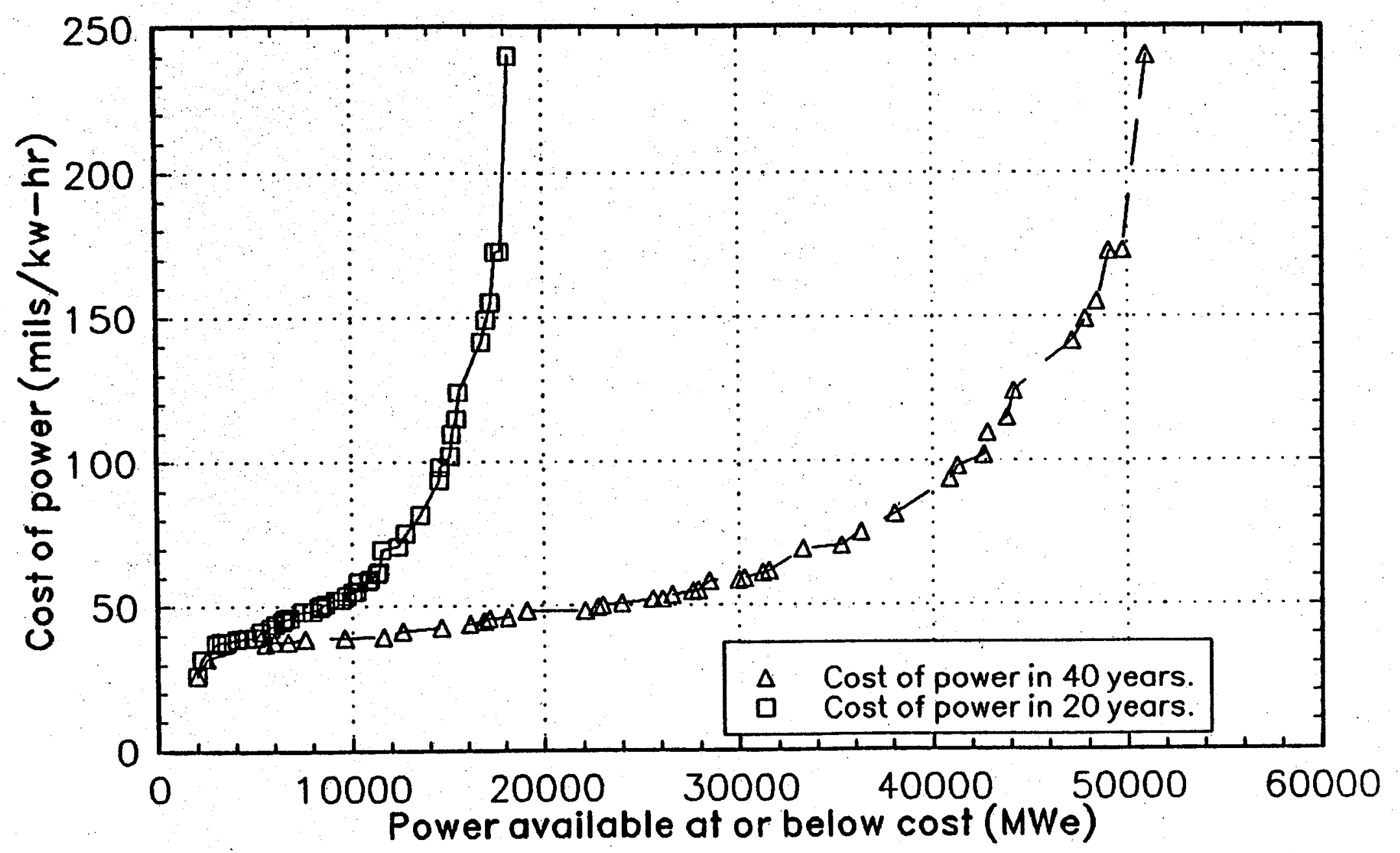


SUPPLY OF GEOTHERMAL POWER AT COST

Region 6 , increased research, unidentified resources included.

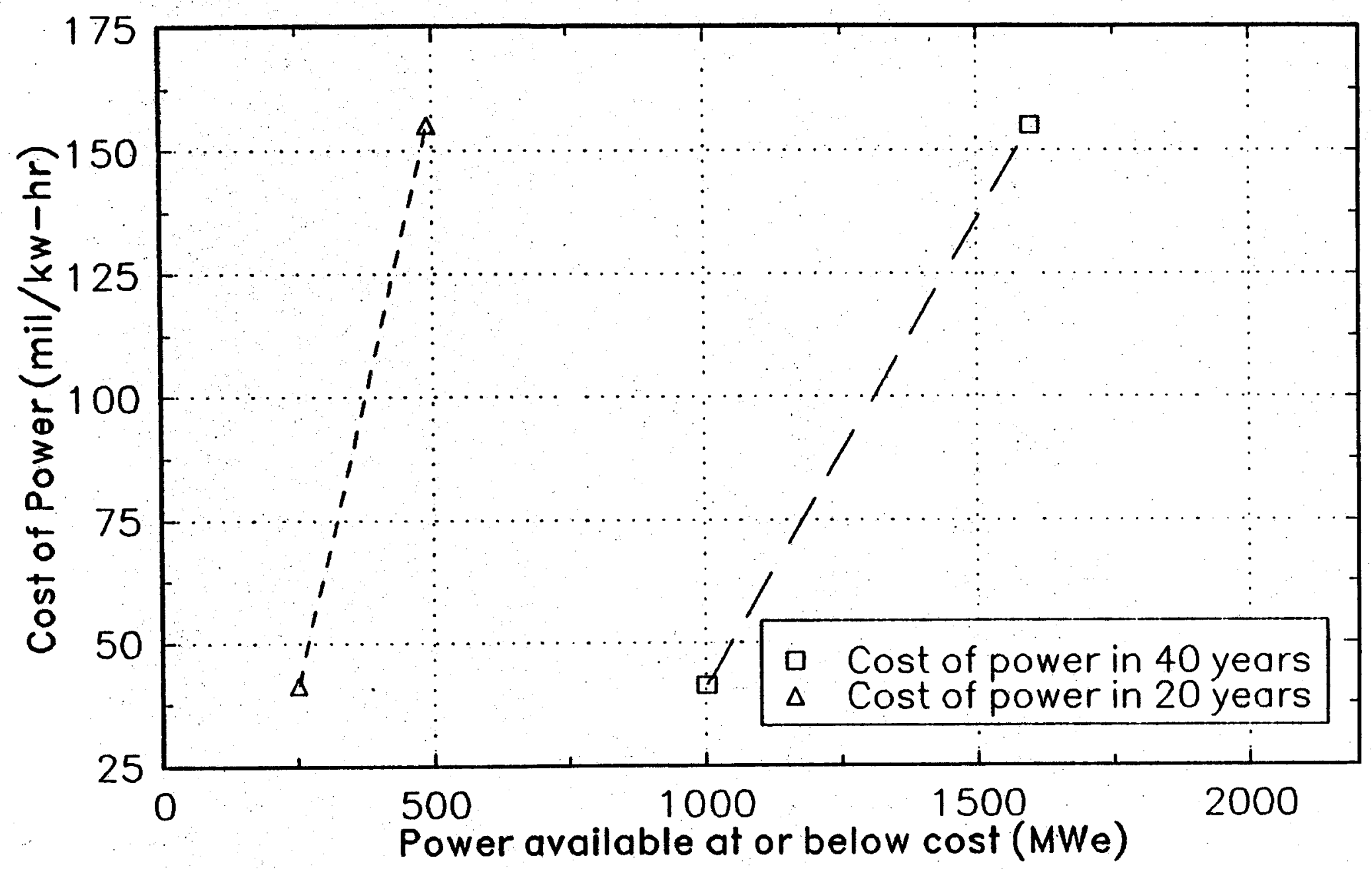

SP Consulting 
SUPPLY OF GEOTHERMAL POWER AT COST

Region 8 , increased research, unidentified resources included.

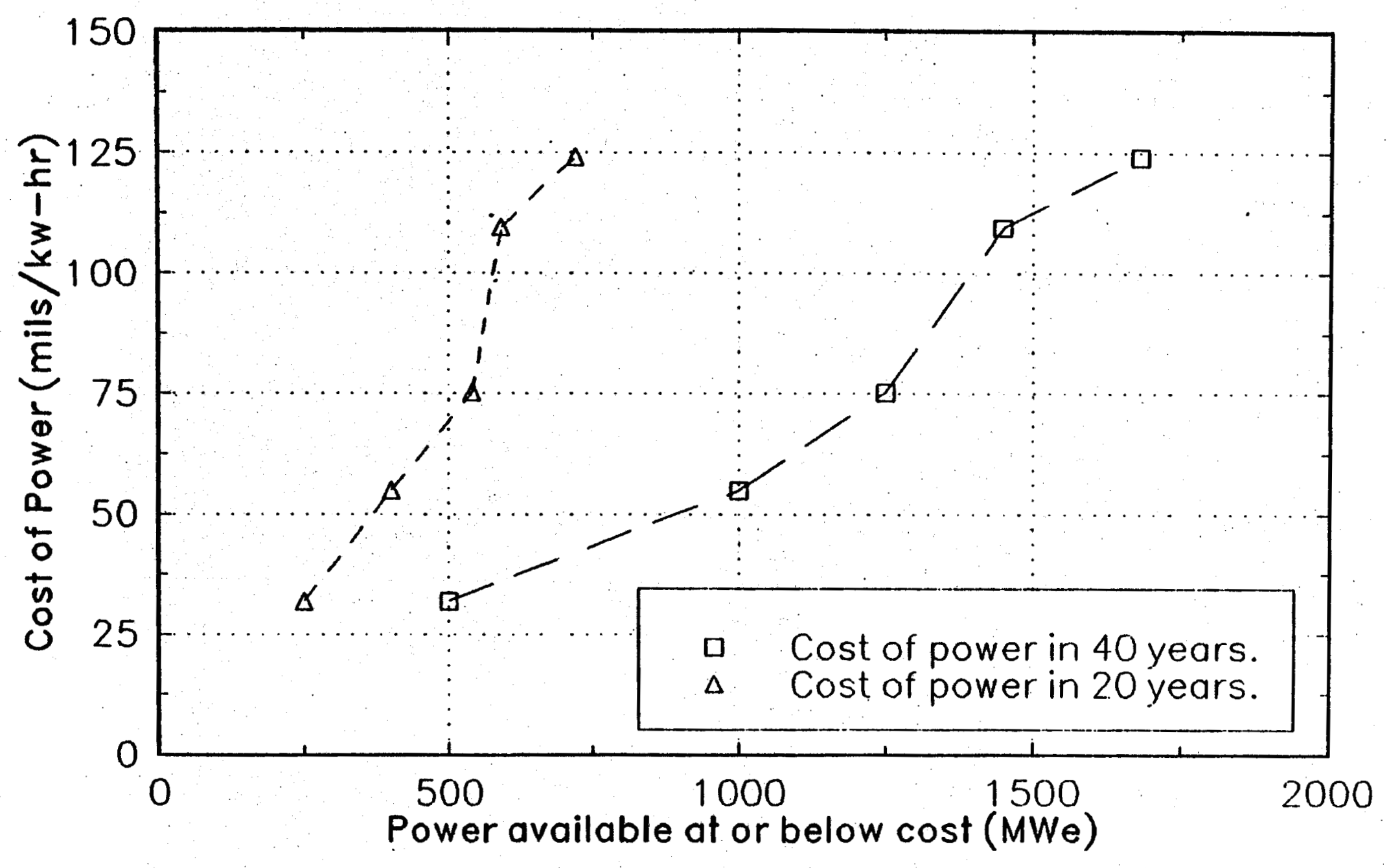


SUPPLY OF GEOTHERMAL POWER AT COST Region 9, increased research, unidentified resources included.

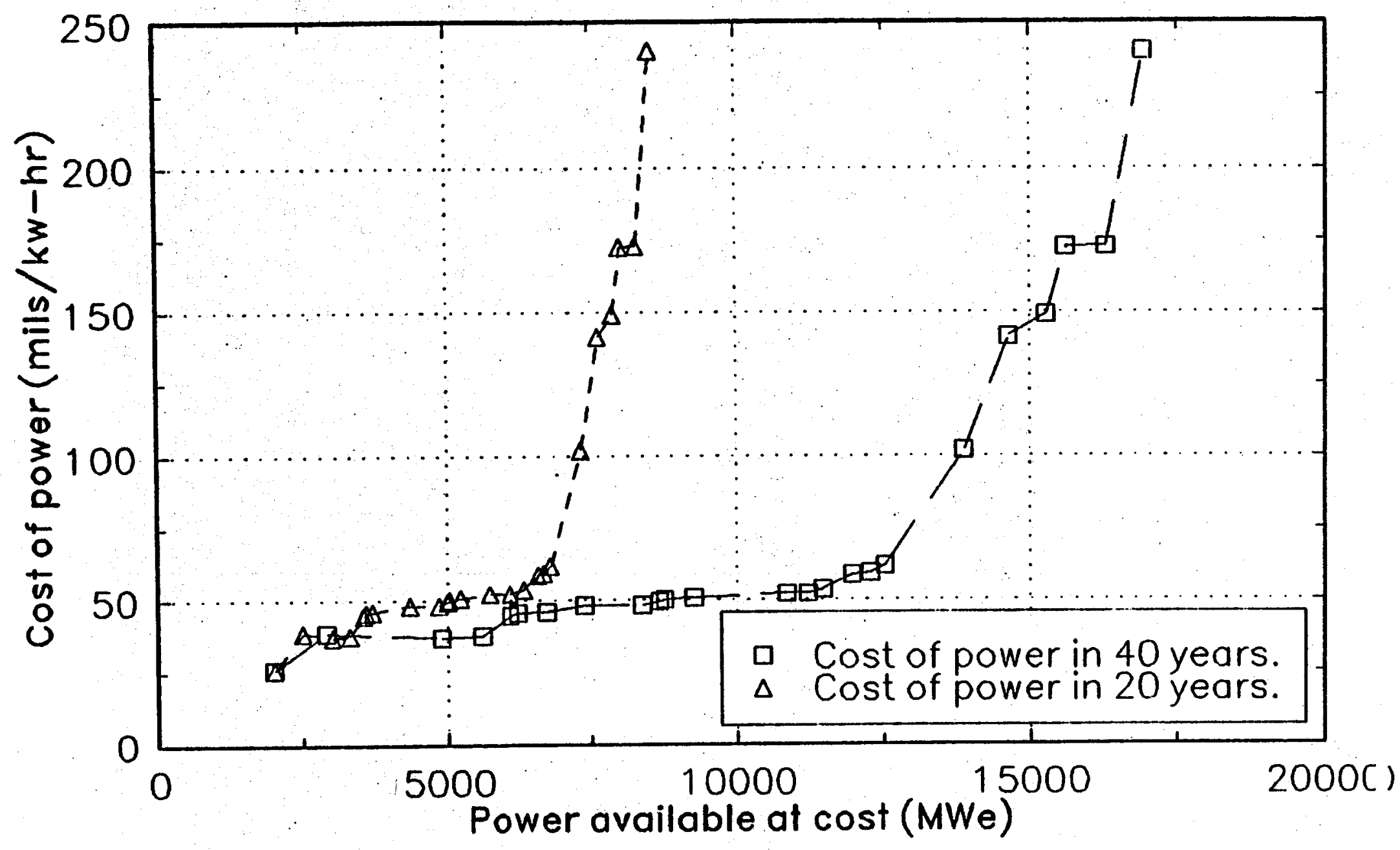


SUPPLY OF GEOTHERMAL POWER AT COST

Region 10 , increased research, unidentfied resources included.

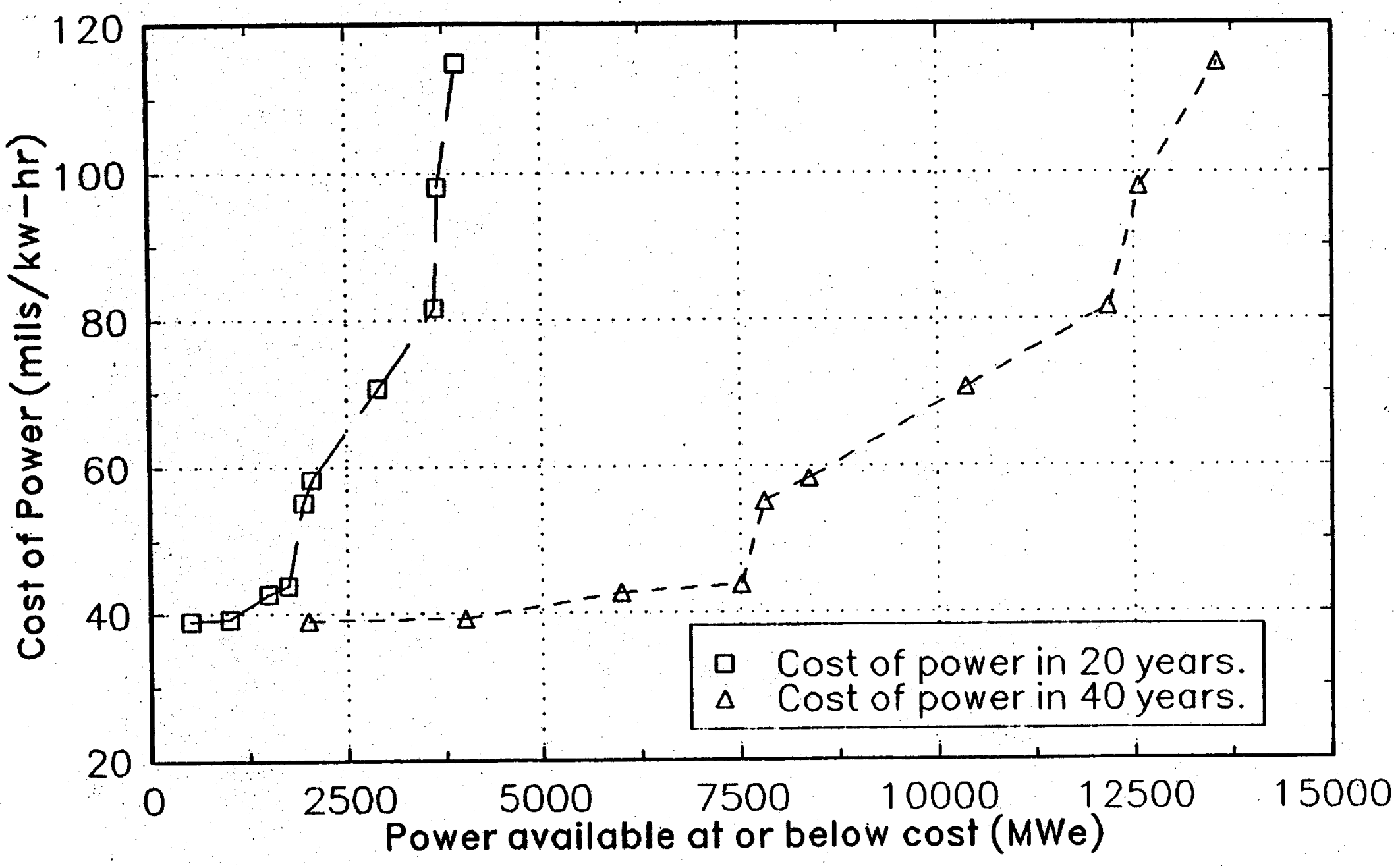


APPENDIX D 
RESERVOIR DATA FOR COMPOSITE SITES:

Input for IMGEO Calculations

\begin{tabular}{|c|c|c|c|c|}
\hline RESOURCE & $\begin{array}{l}\text { TEMP } \\
\text { deg. } F \\
\end{array}$ & $\begin{array}{c}\text { SIZE } \\
\text { MW }\end{array}$ & $\begin{array}{l}\text { DEPTH } \\
\text { feet }\end{array}$ & $\begin{array}{l}\text { FLOW } \\
\text { RATE }\end{array}$ \\
\hline SURPRISE VALLEY & 320 & & 4000 & 600,000 \\
\hline Now & & 25 & & \\
\hline 20 Years & & 500 & & \\
\hline Total & & 1490 & & \\
\hline $\begin{array}{l}\text { LASSEN } \\
\text { (Outside park) }\end{array}$ & 420 & & 3500 & 350,000 \\
\hline Now. & & 0 & & \\
\hline 20 Years & & 116 & & \\
\hline Total & & 116 & & \\
\hline $\begin{array}{l}\text { CLEAR LAKE } \\
\text { Saline liquid }\end{array}$ & 650 & $\vdots$ & 10,000 & 300,000 \\
\hline Now & & 60 & & \\
\hline 20 Years & & 500 & & \\
\hline Total & & 900 & & \\
\hline $\begin{array}{l}\text { LONG VALLEY } \\
\text { LOW temperature }\end{array}$ & 350 & & 1000 & 600,000 \\
\hline Now & & 50 & & \\
\hline 20 Years & & 250 & & \\
\hline Total & & 500 & & \\
\hline $\begin{array}{l}\text { LONG VALLEY } \\
\text { High temperature }\end{array}$ & 500 & & 6000 & 400,000 \\
\hline Now & & 0 & & \\
\hline 20 Years & & 500 & & \\
\hline Total & & 1600 & & \\
\hline $\cos 0$ & 550 & & 5000 & 550,000 \\
\hline Now & & 300 & & \\
\hline 20 Years & & 650 & & \\
\hline
\end{tabular}




\begin{tabular}{|c|c|c|c|c|}
\hline Total & & 650 & & \\
\hline RANDSBURG & 340 & & 1600 & 500,000 \\
\hline Now & & 10 & & \\
\hline 20 Years & & 50 & & \\
\hline Tota 1 & & 84 & & \\
\hline SALTON SEA & 613 & & 7500 & 550,000 \\
\hline Now & & 500 & & \\
\hline 20 Years & & 2000 & & \\
\hline Total & 3 & 3400 & & \\
\hline WESTMORLAND & 465 & $\therefore$ & 8000 & 350,000 \\
\hline Now & & 25 & & \\
\hline 20 Years & & 150 & & \\
\hline Tota 1 & & 1710 & & \\
\hline GEYSERS & 400 & & 6000 & 150,000 \\
\hline Now & & 1988 & & \\
\hline 20 Vears & & 2000 & & \\
\hline Total & & 2000 & & \\
\hline BRAWLEY & 525 & & 11000 & 500,000 \\
\hline Now & & 150 & & \\
\hline 20 Years & & 350 & & \\
\hline Total & & 640 & & \\
\hline EAST MESA & 350 & 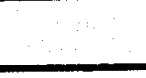 & 3500 & 750,000 \\
\hline Now & & 60 & & \\
\hline 20 Years & & 100 & & \\
\hline Total & & $360^{\circ}$ & & \\
\hline HEBER & 350 & & 4000 & 500,000 \\
\hline Now & & 150 & & \\
\hline 20 Years & & 350 & & \\
\hline Tota 1 & & 650 & & \\
\hline $\begin{array}{l}\text { COVE CREEK/ } \\
\text { CRANE CREEK }\end{array}$ & 325 & & 3500 & 500,000 \\
\hline Now & & 10 & & \\
\hline
\end{tabular}




\begin{tabular}{|c|c|c|c|c|}
\hline 20 Years & & 200 & & \\
\hline Total & & 300 & & \\
\hline REXBURG & 450 & & 11000 & HDR \\
\hline Now & & 0 & & \\
\hline 20 Years & & 0 & & \\
\hline Total & & 500 & & \\
\hline ISLAND PARK & 450 & & 7500 & 500,000 \\
\hline Now & & 0 & & \\
\hline 20 Years & & 250. & & \\
\hline Total & & 3000 & & \\
\hline $\begin{array}{l}\text { RAFT RIVER/ } \\
\text { other similar }\end{array}$ & 280 & & 6000 & 600,000 \\
\hline Now & & 10 & & \\
\hline 20 Years & 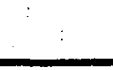 & 30 & & \\
\hline Total & & 53 & & \\
\hline BLACKFOOT LAVA FIELD & 450 & & 10000 & HDR \\
\hline Now & & 0 & & \\
\hline 20 Years & & 0 & & \\
\hline Total & & 250 & & \\
\hline MEDICINE LAKE & 550 & 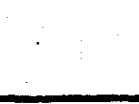 & 4500 & 1000000 \\
\hline Now & & 50 & & \\
\hline 20 Years & & 500 & & \\
\hline Total & & 2000 & & \\
\hline STEAMBOAT & 400 & & 3000 & 600,000 \\
\hline Now & & 25 & & \\
\hline 20 Years & & 55 & & \\
\hline Total & & 350 & & \\
\hline DIXIE VALLEY & 500 & & 9500 & 750,000 \\
\hline Now & & 60 & & \\
\hline 20 Years & & 150 & & \\
\hline Total & & 250 & & \\
\hline
\end{tabular}




\begin{tabular}{|c|c|c|c|c|}
\hline FALLON AREA & 376 & & 5000 & 250,000 \\
\hline Now & & 10 & & \\
\hline 20 Years & & 100 & & \\
\hline Tota1 & & 660 & & \\
\hline DESERT PEAK & 430 & & 6000 & 400,000 \\
\hline Now & & 10 & & \\
\hline 20 Years & & 100 & & \\
\hline Total & & 750 & & \\
\hline BEOWOWE & 425 & . & 5000 & 400,000 \\
\hline Now & & 15 & & \\
\hline 20 Years & & 50 & . & \\
\hline Total & & 130 & & \\
\hline NEWBERRY & 470 & 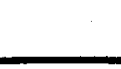 & 3000 & 450,000 \\
\hline Now & 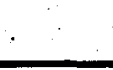 & 0 & & \\
\hline 20 Years & & 200 & & \\
\hline Total & & 1500 & & \\
\hline ALVORD DESERT & 350 & & 3000 & 500,000 \\
\hline \multicolumn{5}{|l|}{ Now } \\
\hline \multicolumn{5}{|l|}{20 Years } \\
\hline \multicolumn{5}{|l|}{ Total } \\
\hline KLAMATH FALLS AREA & 360 & & 650 & 750,000 \\
\hline Now & & 0 & & \\
\hline 20 Years & & 100 & & \\
\hline Total & & 676 & & \\
\hline ROOSEVELT & 510 & & 4000 & 850,000 \\
\hline Now & . & 30 & & \\
\hline 20 Years & & 250 & & \\
\hline Total & $\cdots$ & 500 & & \\
\hline COVE FORT & 400 & & 8000 & 750,000 \\
\hline Now & & 10 & & \\
\hline 20 Years & & 100 & & \\
\hline Total & & 500 & & \\
\hline
\end{tabular}




\begin{tabular}{|l|r|r|r|r|}
\hline KLAMATH FALLS & 360 & & 650 & 750,000 \\
\hline Now & & 0 & & \\
\hline 20 Years & & 100 & & \\
\hline Total & & 576 & & \\
\hline
\end{tabular}


U.S. Department of Energy (5) Geothermal Division Attn: Ted Mock

$$
\begin{aligned}
& \text { Alan Jelacic } \\
& \text { Lew Pratsch } \\
& \text { Gladys Hooper } \\
& \text { Marshall Reed }
\end{aligned}
$$

Forrestal Bldg., CE-324

1000 Independence Avenue SW

Washington, DC 20585

James B. Combs

Geo Hills Associates

27790 Edgerton Road

Los Altos Hills, CA 94022

Steve Pye

Unocal Geothermal

P.O. Box 7600

Los Angeles, CA 90017

B. J. Livesay

Livesay Consultants, Inc.

126 Countrywood Lane

Encinitas, CA 92024

Susan Petty

Susan Petty Consulting

654 Glenmont Avenue

Solana Beach, CA 92075

Meridian Corporation (2)

Attn: Dan Entingh

Kathy Manger

$4300 \mathrm{king}$ street, suite 400

Alexandria, VA 22302-1508

4112 K. G. Pierce

6111 J. C. Dunn (30)

7022 R. R. Traeger (5)

7141 Technical Library (5)

7151 Technical Publications

7613-2 Document Processing for DOE/OSTI (10)

8523-2 Central Technical Files
Jim Disbrow

Energy Information Administrator EI-53I

U.S. Department of Energy

1707 H street NW

Washington, DC 20585

William P. Long

Carlin Gold Company, Inc.

1240 East Main Street, Suite 3

Grass Valley, CA 95945

John Geyer

John Geyer and Associates

11914 Northeast 18th Street

Vancouver, WA 98684 